\title{
A BOOK OF
}

THE WILDERNESS

AND JUNGLE

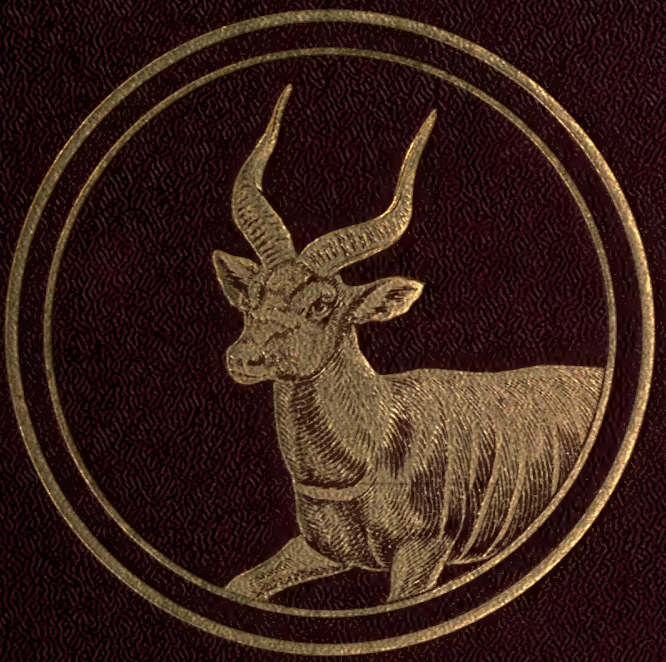

F. G. AFILALO H.R.G.S. 
Digitized by the Internet Archive in 2007 with funding from Microsoft Corporation 




\section{A BOOK OF THE WILDERNESS AND JUNGLE}




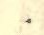





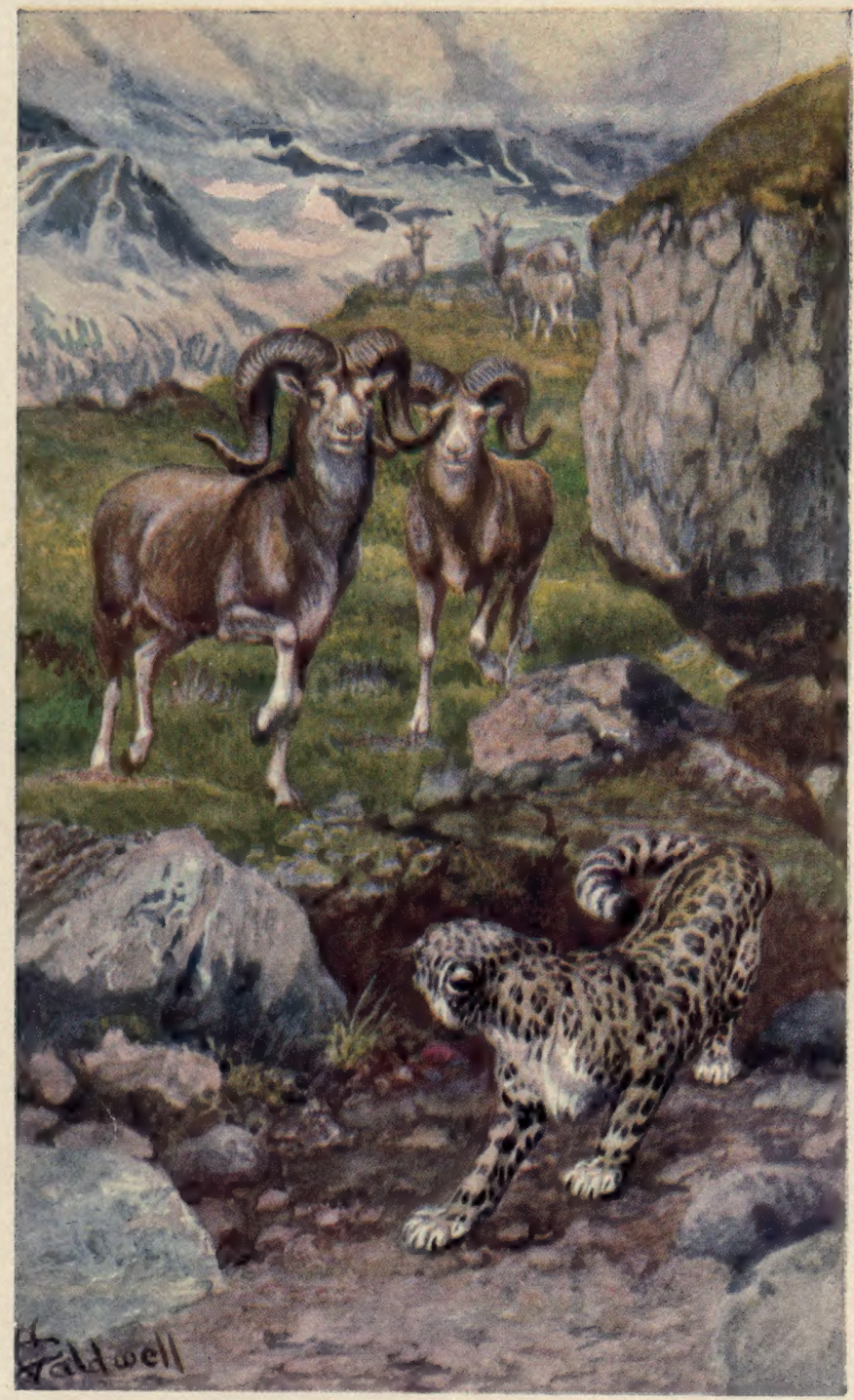

"THE WATChFulNess OF the ARgali." 


\section{A. BOOK OF}

\section{THE WILDERNESS}

\section{AND JUNGLE}

EDITED BY

F. G. AFLALO, F.R.G.S.

AUTHOR OF "OUR AGREEABLE FRIENDS"

ILLUSTRATED IN COLOUR AND BLACK AND WVHTE BY E. F. CALDWELL

LONDON

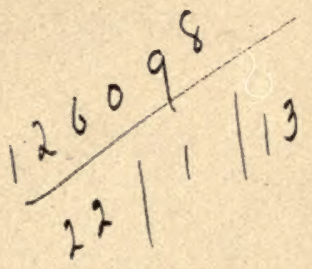

S. W. PARTRIDGE \& CO., LTD.

OLD BAILEY 


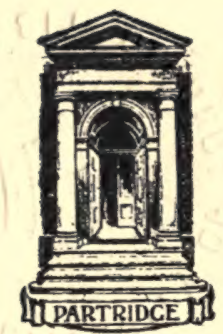




\section{CONTENTS}

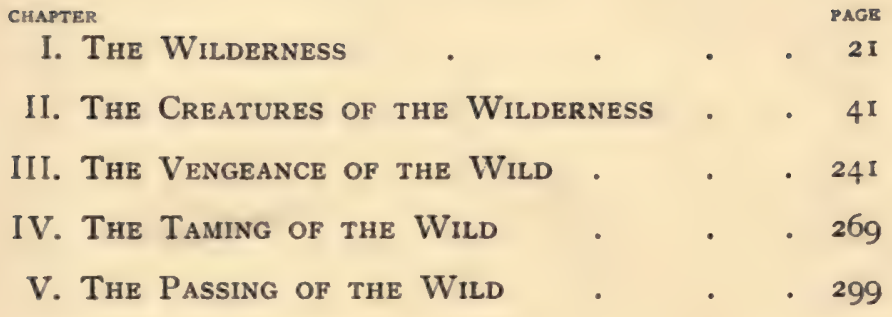





\section{LIST OF ILLUSTRATIONS}

\section{IN COLOUR}

"The Watchfulness of the Argali" Frontispiece

"Full on a Great Moose" . . Facing page 28

"The Boar thinks little of Drinking AT THE SAME Waterhole" . . . . 74

"From the Cattle to their Driver WAS BUt A STEP" . . . . . , 104

"Clean Through a Herd of HarteBEEST"

"So as to Break the Lion's Jaw" . , , 192

IN BLACK AND WHITE

"And Hissed Savagely at the Boar" ", 76

"Back Came the Elephant in no End OF A HURRY" . . . . . . . . " , 96

"The African Rhinoceros Uses its HORN FOR TOSSING ITS ENEMY" . . 184

A Rare Antelope . . . . . , , 204

The Meal that might have been a , , 232

"It Manages to Jump on the Jaguar's BACK" . . . . . . . , 236 



\section{PREFACE}

A PREFACE usually explains, or professes to explain, why a book is written. It may, as a rule, be taken as read that scores of friends have urged the author not to keep his knowledge from the world. These friends then expect copies of the book when it appears. I cannot plead any such wholesale mandate. The book was written at the invitation of the publishers, and for reasons not unwelcome to those who write books.

Yet I would not have set about it if it had not seemed to fill a gap. It attempts, in fact, to be a kind of Nature-study book on the larger scale, an introduction to the study of big game in our overseas possessions. It is not merely a book of adventure with wild animals, though its pages contain many thrilling stories of actual encounters told by those who took part in them. But it aims at something over and above this sensational treatment of the subject.

Many volumes have been published during 
the last few years on what is known as Natureteaching. Some of these are very good, others only good, and further grades need not be specified. All of them attempt, more or less successfully, to rouse an interest in wild life, animal and vegetable, and to moderate the thirst for destroying it. The rare fern is treated as respectfully as the rare butterfly. There can be no doubt whatever that the excellent Boy Scout movement has in great measure been responsible for this literature, for there is obvious necessity for encouraging this combination of observation and restraint in an immense body of youngsters suddenly turned loose, often without the embargo of trespass, in the most peaceful corners of England. Therefore book after book appears in which the Boy Scouts (and other boys who are too lazy to scout) are taught to watch squirrels without catapulting them and count the eggs in the blackbird's nest without taking them. This is very admirable doctrine, and, so far as England is concerned, it could not be bettered. All lads are not, however, destined to stay in England. Many-one might say most - of the best and brightest turn their eyes to other 
lands, either in adventurous ambition to see the world, or from sheer compulsion to make their way in life with greater opportunities than they can find in the Old Country. Necessity, then, and choice combine to send thousands of young fellows every year to India, Africa, Canada, or those farther colonies that lie on the other side of the world. In one sense, no doubt, the Mother Country is the loser by this steady drain on the best of her blood, and it has even been compared with the loss of the strongest and bravest of her manhood in war. Yet there is this difference that, whereas those who fall in battle are gone for all time, many who make a career overseas return home to end their days. This is true of practically all who, as soldiers, civil servants, or planters, go to India; and those who, in the kinder climates of other outposts of the Empire, settle permanently in their adopted home, remain loyal at heart to the old country and rally round her when she needs them.

This book, then, is intended as an introduction to Nature Study in those vast territories beyond the seas over which the British flag is still kept flying. How different are they from 
12 THE WILDERNESS AND JUNGLE this little "Great" Britain of ours-of the quiet meadows with their moles and rabbits, little woods that would scarcely hide an elephant, rivers that are mere rills, lakes that might be ponds, and mountains little more than anthills when compared with the splendid majesty of Himalaya or the Rockies. Instead of such miniature scenes, we have to consider the Wilderness-desert, jungle, or mountainvast, mysterious, in parts still untrodden by man, and the last stronghold of many beautiful or interesting creatures on the verge of disappearance.

Here also, with some exceptions, the spirit of moderation should be encouraged, and something is said of this in the concluding chapter. The Passing of the Wild is inevitable, but it may be indefinitely delayed by well-framed game-laws, which should limit the bag in the case of all animals save those which are dangerous, and which should entirely protect such species as are threatened with extinction. The "Society for the Preservation of the Wild Fauna of the Empire" has chosen a clumsy title, but does admirable work in this direction, and an equally satisfactory spirit of 
protection has, even at the eleventh hour, become apparent in the nation which drove the wild buffalo of the prairies off the face of the earth.

At the same time, it is necessary to use common sense in framing these regulations and to recognise that the injunction to spare life cannot be worded as peremptorily in the African or Indian jungle, as, for instance, in Epping Forest. For one thing, many of the wild animals are exceedingly savage and dangerous. The lion, tiger, and leopard, to quote only three, do not hesitate to attack natives and annually destroy immense quantities of cattle, sheep, goats, and poultry. Europeans, it is true, are, as a rule, not molested by these animals unless they wound them first, though even to this immunity there are exceptions. But Europeans are morally responsible for the safety and well-being of those whose birthright they administer, and they should consider themselves bound to shoot every lion or tiger they may come across, even at some personal risk and discomfort. In the chapter entitled "Vengeance of the Wild" the reader will find details of terrible encounters with 


\section{THE WILDERNESS AND JUNGLE}

infuriated wild animals, many of them ending in the sportsman's death, others involving escapes little short of miraculous. No one, after reading these stories, is likely to plead for the protection of lions and tigers, at any rate, though there are, no doubt, people who hold it wicked to kill a flea.

Again, it must be borne in mind that those who travel in the heart of a country like Africa, even where sport is not the primary object of their expedition, must provide meat for their native followers as well as for themselves, and the negro eats a deal of meat when on the march. It would be ridiculous to forbid the shooting of antelopes, or even ot an occasional giraffe or hippopotamus, with so many mouths to feed. It is easy for stay-at-home folk, with a butcher's shop round the corner, to preach such comfortable doctrine, but out in the wild places life is measured by other standards than those that suffice the complacent folk of cities.

Last, but not least, there is the freedom of sport. I am not going to insist, in the thrilling language of a florid prospectus recently issued with a sporting work of reference, that "our national games make national heroes," for I 
am of those unappreciative people who believe that a man may be a hero even though he has never watched a football match or shot a pigeon out of a trap. At the same time, there can be very little doubt that those who have the courage and endurance to go into the jungle after tiger, or into the Himalaya after wild sheep, learning, as they go, the virtue of dogged patience and the arts of woodcraft, stalking, intercourse with native tribesmen and getting over difficult country in quick timethese men must be valuable assets to their country in the hour of their country's need. While, therefore, sportsmen should be subjected to fair and reasonable restraint, made to pay for their amusement, debarred from killing more than a strictly limited number of beasts, and utterly prohibited from shooting the females of some and both sexes of others, it would be a bad day that should see the sport of big game hunting unconditionally forbidden or, worse still, losing its attraction for Englishmen abroad. This book does not pretend to offer information as to camping requisites or rifles, though hints as to season and locality will here and there be found. Many adven- 


\section{I6 THE WILDERNESS AND JUNGLE}

tures with dangerous game are related in its pages, and most of these have been specially contributed. There is, however, no account of shooting either giraffe or hippopotamus, for these should be shot only when meat is needed for the natives, and such grisly necessity does not fall under the head of sport. There is a single interesting story of an elephant hunt in Rhodesia. If the admission of this narrative should be at variance with the view expressed elsewhere in the book on the pity of slaying so grand a creature for its ivory, it must be remembered that, when wounded at any rate, and sometimes even without provocation, an elephant is one of the most terrible of all wild animals, and, as will be seen in Chapter III, only one other, the lion, has killed so many men in the history of African sport and exploration.

There will also be found an exciting narrative of the manner in which the native Arab hunters ride down the giraffe, killing the animal with their wonderful two-handed swords. This kind of hunting has not often been witnessed by Europeans, and this account, contributed by an officer who actually took part, was too interest- 
ing to omit. Moreover, though we rightly regard the giraffe as a creature worthy of protection from the tourist's rifle, it is perfectly legitimate for these native swordsmen to kill it by such means for the sake of its meat, as the animal is bagged only after an arduous chase, not wholly free from danger.

There is a third possibility in our relations with the wild creatures in addition to the alternative of either killing them or leaving them in peace. We can tame them, and the subject is fraught with such interesting traditions in the past and such curious possibilities for the future that it has been thought worthy of a short chapter to itself, dealing not so much with the horse, dog, and other domestic animals familiar at home, as with the camel, reindeer, yak, and such beside as still exist in the wild state. There are, it is true, wild horses in a restricted area of Western Asia, and, in a sense also, there are wild dogs, but the relationship is less close than in the case of those named above.

For the uninspired descriptions of some aspects of the Wilderness, which form the subject of the opening chapter, I am humbly apologetic. My sense of futility in making this 
unavoidable attempt is the more disheartening because I actually have been in such places and even made notes of what most impressed me at the time and on the spot. None the less, they beat me, utterly. Perhaps those describe them best who know them least. I understand that the most lifelike pictures of battle and the most realistic accounts of executions have been achieved by gifted men who never witnessed either, and I know one writer, at any rate, who has given us the most convincing pictures of the wilderness without ever having set foot within a hundred miles of it. Such imagination is a blessed gift which my fairy godmother withheld from me and which would have been better than my equipment of pencil and notebook and the desire to see realities. Yet I can only offer the wares that are in my pack.

My heartfelt thanks are due to those who have helped me in the writing of this book. First and foremost I must thank the Editor and Proprietors of The Field for kind permission to quote from its teeming pages anecdotes of shikar, and the Secretary of the Royal Colonial Institute for having placed at my disposal the files of many African and Indian periodicals. 
Then I must record my obligations to the sportsmen who have so generously contributed their experiences, including Mr. Edwin Arnold, Mr. H. A. Bryden, Lord Egmont, Sir Godfrey Lagden, к.c.M.G., Major Stevenson Hamilton, Major Edgar Herapath, D.s.o., Colonel S. J. Lea, c. B., Sir William LeeWarner, G. C.s.I., Dr. Tom Longstaff, Professor Lloyd Morgan, Major Murray, Mr. H. C. de la Poer, Mr. Percy Reid, Sir Henry SetonKarr, c.M.G., Colonel Nevill Maskelyne Smyth, v.c., Colonel Williamson, Major F. G. Talbot, D.s.o., and many others. 

THE WILDERNESS 



\section{THE WILDERNESS}

IT is by no means easy, in the midst of this built-over, cultivated, and thickly peopled England of ours, to realise the great spaces of the wilderness. So destructive of other effects and impressions are the conditions of civilisation, that there is difficulty, even for those of us who have known the wild places, to recall their appearance once we are back in cities. With church spires and factory chimneys cutting the sky in every direction, we are apt to forget the grander symmetry of bamboo and teak. The shriek of the locomotive survives the song of rivers, and the hum of crowds brings unwelcome forgetfulness of Nature's silence. Here and there, even in modern England, in such corners of Salisbury Plain as are not overrun by our brave defenders, or on the lonely heights of misty Dartmoor, away from the trail of the tourist, it is still possible to sense something of the sweeter solitudes; but such opportunities, already few, are dwindling every year. 


\section{THE WILDERNESS AND JUNGLE}

The wilderness eludes me when I try to describe its grandeur, and I realise with profound humiliation the vanity of trying to introduce the reader to the baffling mystery of the forest or the haunting glare of the desert. The witching hour in the forest is that of dawn, and I have loved the cold silence of its waking away in the dreary timberlands of Canada and Russia, as well as in the luxuriant jungle of the Eastern tropics. Such virgin forest gives precious isolation from the little worries of men, and its desolate beauty provides a fitting frame for the last years on earth of many noble animals that are making their final stand against the march of civilisation in these all but impenetrable thickets. It may seem a paradox, but lifelessness is the keynote of these forest scenes.

Sir Henry Seton-Karr tells me that he once walked right on an old bull buffalo asleep in the open plains of Africa, getting to within five yards of the animal before it woke up. This he regards as a very unusual case, the only one, indeed, within his wide experience of many continents. Indeed, even where not much hunted, and, in consequence, not afraid of man, this curious alertness is typical of all the wild creatures.

Though animals of the open plain depend mainly on their eyesight for keeping out of 
danger, the jungle creatures owe their safety to scent or hearing. Sir Henry Seton-Karr thinks that jungle game rarely move until absolutely certain of the danger. He tells me that he once rode, in the heart of the Rocky Mountains, within a hundred yards of a blacktail buck, which stood among some trees and there, no doubt, thought itself hidden from view. The party did not happen to want the animal and so rode on. The buck stood so motionless that it might have been carved in stone. Just as the rest were riding out of sight, Sir Henry pulled up and looked steadily at the buck, which in a flash bounded out of sight. He also remembers having a driven red-deer hind pass him within twenty yards as he sat on a $\log$ in the heart of a Norwegian pine-forest. Had she got wind of him, she would have sprung high in the air and galloped off in another direction. Yet the cunning of woodland deer, when aware of danger, is almost uncanny. Sir Henry once saw a stag deliberately lie down in a pine-forest, wait until the drivers had passed it, and then quietly return to the woods and so out of danger.

Harmony with surroundings, or what is sometimes, though less satisfactorily, called "protective colouring," is very characteristic of many jungle creatures. The same sportsman assures me that even so large an animal 
as the Scandinavian elk, a greyish black deer standing twenty hands and weighing I 500 lbs., is often exceedingly difficult to see in its native pine-forests. The elephant of the African cedar-forest fits its background so perfectly that a sportsman has before now been known to see nothing of one till he suddenly became aware of its trunk waving gently almost over his head. On one occasion, indeed, Sir Henry himself, while hunting in an African watercourse, nearly sat on a sixteen-feet python. "'But," as he quaintly adds, "the African jungle is full of surprises."

Those who have never wandered in the jungle, knowing it only in books of adventure, picture it alive with animals that show themselves at all hours. The truth is that they are all in hiding, and can be seen only in one of two ways, by either watching silently, or by driving the forest with a host of beaters. The latter, which is the more usual method with those in a hurry, gives only a fleeting glimpse of the jungle-folk under most unnatural conditions, as they fly panic-stricken for their lives. He who sits up at night in a machan comes nearer to the truth.

I remember such a daybreak, in the depth of winter, in a Russian forest a hundred and fifty miles from St. Petersburg. To reach this outlandish spot, it had been necessary to drive 
from the nearest station on the Trans-Siberian Railway in an open country cart over miles of snow and ice, and to be ferried, cart and all, across a half-frozen river at the hour of midnight. It was not what might be called luxurious travel. Nor, at journey's ending, was there soft luxury in the little hut of snow and boughs in which I was presently enclosed with my rifle and bidden to crouch till break of day, not even daring to smoke for fear of scaring the game. In the sequel, the game showed no appreciation of my self-denial and stayed away. Not a sign did I see of anything more terrible than a hare, though this vast Government forest is well stocked with bear, elk, wolves, and other wild animals. Yet I am quite as certain now as I was even in the disappointment and discomfort of the moment that the awakening of that far northern forest, as little birds broke into song and the feeble sun crimsoned the sparkling branches, more than repaid me for the cold and sleepless night that went before.

Less rigorous, and even more attractive, is another picture I recall of daybreak, one summer's morning, in a lonely forest of New Brunswick, camped on the left bank of the singing Miramichi. Here, in untrodden backwoods, I stayed for ten days, far from the haunts of man, poling down the stream in a 


\section{THE WILDERNESS AND JUNGLE}

crazy dug-out, camping each night beside some likely salmon pool, bathing, fishing, dozing, as I watched the wild creatures of an evening, living in unconditional surrender to the irresistible spell of the wilderness. That was the forest primeval that Longfellow sings of in "Evangeline," and through it ran the turbulent river, singing loudly as it wound along to the Gulf of St. Lawrence, babbling of the voyageurs and the coureurs des bois who are gone. Fir and larch and spruce and pine, with patches of hardwoods between, shot up tall, straight, and slender along both banks, and modest wild flowers made the clearings gay with colour. It is true that few of the trees showed great stature, for forest fires have taken heavy toll of the Lower Provinces, and most of the timber now standing is second growth, yet the peace of the Canadian wilderness is white magic. Its stillness deafens ears accustomed to the roar of traffic. As I lay down at night on the aromatic bed of fir-boughs piled by the guide, and lazily blinked at the last dying embers of the camp fire, the still darkness seemed to reverberate with sound, and it was not until after some interruption in the shape of a clumsy porcupine nosing among the stores, or a startled deer dashing through the clearing, that the silence made itself felt. The most entrancing waterways in the backwoods are the 


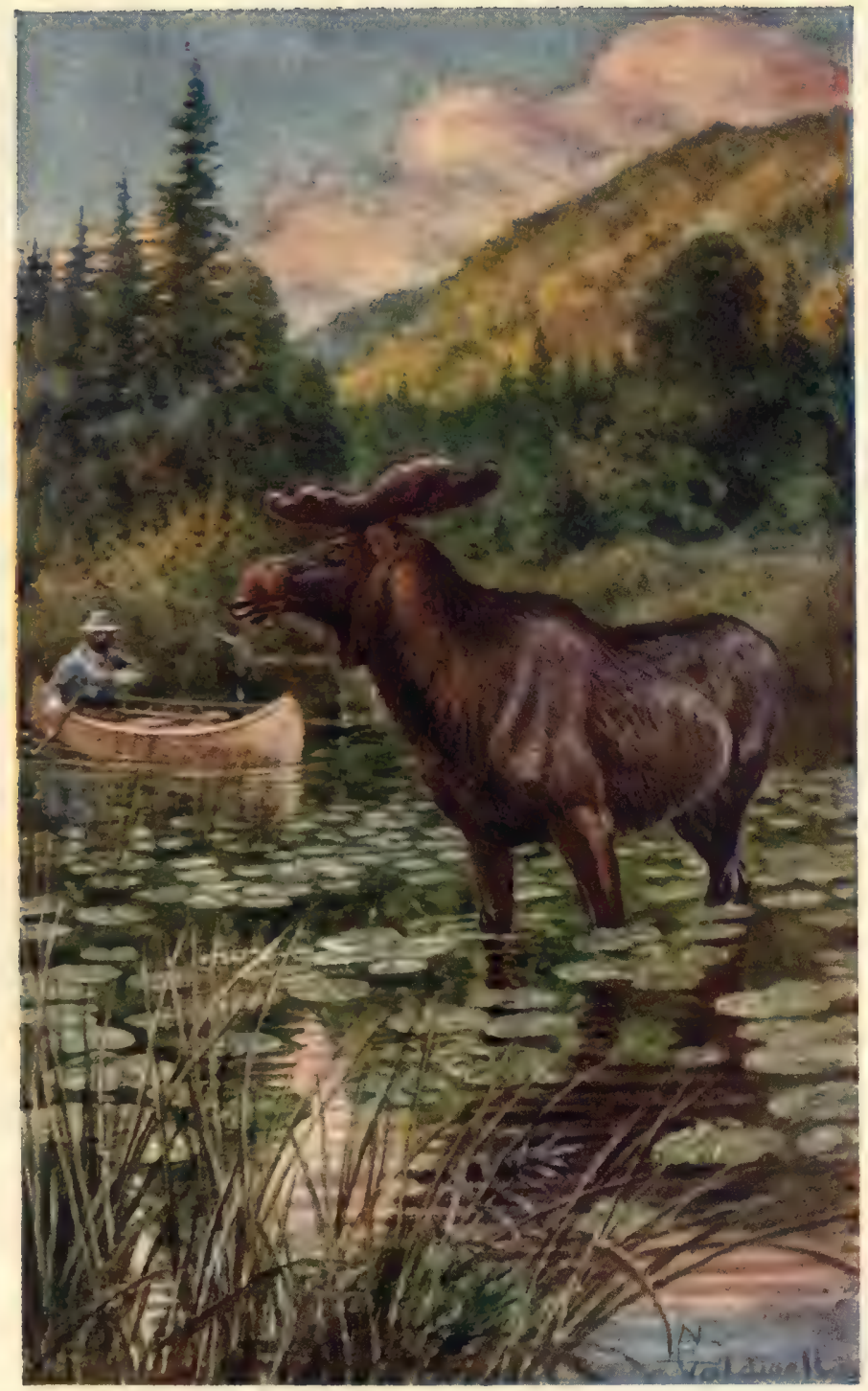

“... FULL ON A GREAT MOOSE ... 

brooks tributary to the main river and running to it from hill or lake beneath a lattice archway of greenery. Gliding silently down such a brook, my canoe shot one evening round a bend and full on a great moose that was busy crunching the lily-pads. So intent was the clumsy deer on its summer salad that a few moments elapsed ere the ugly head went up, and then, with a defiant snort of anger at being disturbed, the giant went full gallop up the steep bank, and turned again on a hill-top to snort again before crashing away into the timber.

Very different from these northern forests, yet akin with the spirit of the wilderness, is the eastern jungle, with its massive pillars of teak and bamboo and deodar, its fern-clumps and giant rhododendrons, and the serpentine creepers gay with gorgeous blooms. Here, too, are veritable seas of high grass, and the carpet is woven of ragwort, thistle, violet, cineraria, and other homelike flowers. Perched amid the hills in the forest are native villages, and down in the plains are ruined temples, steaming paddy-fields, and deserted tanks. The light in the eastern jungle is mystic. A strange, impressive gloom, in extraordinary contrast to the blinding glare in the open, pervades the aisles and transepts of Nature's temples. There are times when this unearthly 
light looks green, then blue, like that of a seacavern, and there is indescribable beauty in the changing effects as the sunlight filters through the leafy screen. Over all these tropical scenes, over cool forest and burning desert, broods the pitiless brazen sky, of copper hue throughout the day, but passing morning and evening through every shade of blue, indigo, turquoise, and back to ultramarine, violet as the sun goes down over the edge of the desert, and, just at the last, an uncanny green. I have noticed this strange green ending to the day in two arid regions, Egypt and Arizona, just after the going of the sun, and never in the open elsewhere.

Another scene, almost within the tropics, not beautiful, perhaps, but with a picturesqueness of its own, is to be found among the swampy Keys of Florida. In the early part of the year, when the sun still tempers strength with mercy, and the mosquitoes are not yet alive to their opportunities, this is a very pleasant land to do nothing in. Laziness is its creed. Like the alligators and the turtles, mankind in that region moves only under compulsion, and always unwillingly. In these mangrove swamps millions of fiddler-crabs lie basking in the sun, scuttling back to their burrows when disturbed with a noise like that of rushing water. Heavy reptiles lurk in the 
rank vegetation, and through evergreen curtains peep the herons and the egrets which Audubon described so well a hundred years ago, but which, alas! have been so ruthlessly destroyed by those who trade in feathers that the well-meant efforts of American societies organised for their protection come too late. Here also are bears and jaguars, though I did not, even in the wildest nooks of the Everglades, get a glimpse of either. Here, in the silent swamps, we used to dig out alligators amid the music of mocking-birds and the piping of quails, looking up from our labours at the heavy flight of pelicans and turkey-buzzards over the beaches and the more graceful soaring of fish-hawks out over the teeming waters.

Very similar, and to the careless eye identical, are the mangrove swamps of tropical Queensland. Here, however, we knew that there was no wild creature fiercer than the native "cat," little more formidable than our English weasel. The animals most conspicuous out on the burning plains behind the mangroves were the kangaroos and wallabies, grotesque objects which, bounding out of reach of gun or rifle, look as if, embalmed in the Australian bush, they are survivals from some antique period before the dawn of history. The wooded tracts of tropical Queensland, as far north as Albany Pass and 
Whitsunday Passage, are very beautiful, and the same may be said of the vegetation of New South Wales in the foothills of the Blue Mountains. Yet Australian scenes inevitably breathe a sadness that cannot be a figment of imagination, since it appeals to all except those who have made happy homes in the bush and who affectionately regard it as the most inspiring forest landscape in all the world. The visitor, on the other hand, who has no such ties of sentiment to guide his judgment, finds horrible sameness in the miles of gums and wattles, with little or no undergrowth beneath ; and indeed wherever the eucalyptus has been given a new home in India, it has irretrievably ruined the native scenery. No one will blame Australians for their patriotism any more than he would those loyal Dutchmen who would vote the sand-dunes of Holland more impressive scenery than the Trossachs. Yet if the wild Australian bush has its chief attraction for Australians, the splendour of the Botanic Gardens in the cities shows that the native flora affords material that Adam's art can weave into fairy scenes unforgettable after twenty years. Not even the famous gardens at Buitenzoorg, in Java, or the better-known Cinnamon Gardens of Colombo, rich in spreading fig-tree and feathery bamboo, are more lovely than the Botanic Gardens of Australia. 
All through the heat of the day silence is the most memorable quality of the wilderness, jungle, or desert, for only morning and evening, or in the time of darkness, do the beasts and birds make themselves heard. When the sun burns overhead in the pitiless sky, all Nature is silent, too exhausted to move. In early morning, it is true, the jungle is alive with bird-voices, and as darkness falls swiftly on the scene, with none of the lure of our northern twilight, jackals bark plaintively in the foothills, and a sudden scream of pain stabs the gloom as some tiger or leopard comes by its own.

The jungle is less perilous than some people imagine. Beasts of prey lurk in it, no doubt, but, so he be well gaitered against sudden snakes, the European may walk there as safe as in an English wood. People at home find it hard to realise the lack of adventure. Those who write of their experiences are compelled, if they would hold the reader's interest, to choose the days on which something happened. The other days, with nothing to distinguish one from another, are left out of the reckoning and are as if they had not been. It is as if we were to recall only the battles in a country's past and ignore the interludes of peace.

Darkness is another feature of the forest which must be known to be appreciated. Even 


\section{THE WILDERNESS AND JUNGLE}

the heart of a wood at home is cool and shady on the hottest, brightest day of summer, but the giant trees of the tropical jungle, many of them two or three hundred feet in height, so effectually shut out the light of day that the effect is, as already remarked, suggestive of the light of sea-caves, green and ghostly; and perhaps it is this dim, religious light, recalling old cathedrals, that has invested the forest with its uncanny associations. It is silent, solemn, wide and cold, ever reminding us of those submerged coal forests of ancient Britain, in the gloomy recesses of which primeval crocodiles and other vanished reptiles dozed beneath the spreading foliage of clubmosses. Of such impressive age are its greatest trees that the passing of nations leaves them unmoved. Unhappily, this restful effect of permanence belongs only to the forest primeval where the wasteful hand of man has not yet swung the axe and laid the monarchs low. The majesty of these tree giants, as I remember it at Wawona and elsewhere in California, beggars description. The great sequoias stand around silent and contemptuous. They were drinking in the sunshine five thousand years ago, and the monstrous dinotherium may have ended its days in their shadow, long before the coming of man. What, compared with the lifetime of such timber, are the few 
years that we call history? What other vitality do we know, animal or vegetable, equal to theirs, seeing that they live even after coaches are driven through their trunks? The outpost sentinels of the Californian forest are mere shrubs, a hundred feet or so in stature-balsam, cedar, fir, and pine-but some of the veterans measure a hundred feet round their base and tower nearer three hundred feet than two into the clear atmosphere of that beautiful region. Even here the visitor is impressed with the monotony inseparable from pine forests, which are green all the year and irresponsive to the changing seasons. The balm of their resin may be wholesome, yet is less agreeable than the mingled bouquet of English woods. Their groves are not made happy with the song of little birds. Yet they are a grand and exalting sight, these noblest trees on earth, and it is well that the American Government has stationed patrols of cavalry to see that no injury is done them. Thus, a national possession, may they stand for all time against the greed of the builder !

The wilderness, as figured in these pages, embraces all the wild places, from the dried-up veldt under the Southern Cross to the eternal snows of the Himalaya, and another aspect of it is the desert, the Garden of Allah, which, according to a tradition of the Bedawin, Allah 
made out of the rubbish left over at the Creation, planted it with prickly pear and aloes, peopled it with vipers and such-like vermin, and then laughed at the horror of its ugliness. This is a dreadful legend, yet it has in it an element of truth. There are, no doubt, books in which you may read of the beauty of the desert, since beauty is, after all, a matter of taste, and those whose acquaintance with the merciless sand comes from picture galleries may find it beautiful, even as comfortable landsmen, watching a stormy sea from the safety of the cliffs, find it entertaining. But ask the Arabs or the seamen. They will tell another story. On canvas, there may be splendour in the magic of a blood-red dawn, long before which the Arab has folded his tent in the moonlight and stolen away on his trek. There is wonder in the mirage, with its false imagery of trees and caravans that have no being where they seem. Yet this loveliness of the desert is Dead Sea Fruit to its own folk. To the veiled Tuaregs of the Sahara, to the dignified nomads beyond the Jordan, the dawn means another day of merciless heat, the mirage is an illusion that drives thirsty men to the verge of insanity, the sandstorm is a torture to any creature less resisting than a camel. The superstitious children of the desert look on it fearfully as the abode of evil jinns that love 
to torture weak mortals. With some little difference of local colour, there is a dreadful sameness about the "bad lands" all the world over. Here is the Great Thirst : in the Plateau of Gobi, in the Sahara, in the burning sands of Arizona, or the "Never Never" of Australia, everywhere the cloudless, brazen skies, the pitiless sun, the parched earth. The Gardener has planted this waste with spiteful vegetation, spinifex and algarobo scrub, wait-a-bit thorn, saltbush, cactus, and aloes. Ghoulish vultures wheel in the blue on the look-out for some fallen camel, and lazy sand-vipers bask in the sun, scarcely distinguishable from the earth they lie on. The desert may be beautiful in pictures or in poetry, but the reality of it is horrible, and its beauty is the beauty of death.

Each type of scenery has its characteristic creatures, and the influence of the soil, climate and vegetation on their form and character is part of the interesting and much-misunderstood subject of environment, any discussion of which is outside the scope of these pages. What we can at any rate appreciate is the association of jungle, desert, plain and mountain each with its own appropriate group of wild animals. We should not, for instance, expect to find the majority of monkeys far from the forest. We should not look for a grazing animal like the bison in the desert, nor should we seek alpine 


\section{THE WILDERNESS AND JUNGLE}

animals like the sheep and goats in the plains. Every part of the wilderness has its appointed tenants, though some overlapping inevitably arises out of temporary changes of home on the part of migrants. Thus, though nothing seems to attract the wild sheep down to the plains, we find all manner of lowland game, like the bison and the elephant, climbing thousands of feet into the hills in search of cooler weather, fresh pastures and a respite from biting insects, which, if not wholly unknown, are at least less aggressive at the higher levels. The tiger is also encountered at an altitude of six or seven thousand feet, though with what object it performs such journeys is not apparent.

The manner in which many of these creatures have developed certain features, among which various forms of foot are conspicuous, is also of the greatest interest. Thus we find the camel and giraffe with just the type of spreading foot suited to rapid and sure movement over the stony soil of the desert, and the caribou trusting to its splay feet to bear it at top speed over the snow and ice, so that it can outdistance even Indians on their snow-shoes without fear of crashing through the frozen crust in the manner so often fatal to the moose of the same region.

Speaking generally, and with the aforementioned allowance for wanderings, we expect to find types like the tiger, leopard, deer, bison, 
bear and elephant in the forest; the lion and rhinoceros, with antelopes and other horned game, in the open grass plains ; the giraffe, with antelopes and gazelles, in the desert; and the wild sheep and goats, with bears, above the timber on the mountain-sides. The distinction in environment between the lion and tiger is sufficiently illustrated by their respective haunts in Asia. The Asiatic lion is confined to Persia, Mesopotamia and a single forest in Kathiawar. The lions of Gir (Kathiawar) are commonly spoken of as the last surviving Indian members of the species, a statement which implies that lions were at one time common elsewhere in that peninsula. This, however, far from being assured, is exceedingly improbable, for the steaming jungles of the East are far more suited to the tiger. The lion, on the other hand, prefers the moderately dry regions of which it finds such choice in Africa, though it is not partial to the arid desert tracts of that continent in which the giraffe finds sanctuary from its most dreaded natural enemy.

Everywhere we shall find the wild creatures perfectly adapted to their surroundings; not one single mistake in Nature's menagerie. The abnormal extremes of flood or drought may occasion temporary suffering, but these are met, where possible, by migration to kinder conditions. The kangaroo is at home on the 
open plains. Were it driven into forest land, it would break its neck against low branches. The climbing powers of the squirrels and monkeys would be wasted in the plains, so we find them only in the jungle. The keen sight of the vulture is baffled by dense foliage, and the bird soars over open country suited to its strongest sense. The elephant's trunk and the long neck and tongue of the giraffe are clearly adapted to stripping branches of their leaves. Whether these striking types were so created from the beginning, seeking the kind of environment in which they were best qualified to find their food, or whether the elephant developed its trunk, and the giraffe stretched its neck, as circumstances demanded, is a matter of opinion. Each view has its supporters confident of their own case. The wisest man is he who is least sure. 


\section{THE CREATURES OF THE WILDERNESS}





\section{I}

\section{THE CREATURES OF THE WILDERNESS}

If all Englishmen could spend their lives at home, even supposing that the prospect attracted them, they would have no reason to complain that their own country provided them with too little opportunity for either sport or nature-study, since, thanks in great measure to wise laws and also to the exclusion from great private estates of what our American friends pleasantly call "game-hogs," the shooting and fishing in these islands, if in some respects a little artificial, are equal to those of any other country in Europe and superior to the sport of most. Few animal stories are more interesting than those of the fox, the otter, or the red deer; few birds are more attractive to the naturalist and sportsman than the red grouse; few fishes are more exciting to the angler, or more puzzling to the student, than the salmon. No continental country affords finer deer-stalking or salmon-fishing than Scotland, and in none, certainly, is the sport of fox-hunting better understood or more 


\section{THE WILDERNESS AND JUNGLE}

enthusiastically enjoyed than in England. In their early boyhood, therefore, and also in the autumn of life, after long years of work given, it may be, to the service of their country under other skies, Englishmen with a taste for these country pleasures are singularly blest. In middle life, however, a large number must, at one time or another, go abroad, and the burden of exile is considerably lightened by knowing something of the wilderness and its animal life. Nor, in these days of rail and steamer, is it a very far cry from the elms and oaks of English spinneys to the deodars of the Himalaya, the teak forests of Burma, the cold and silent backwoods of Canada, or the steaming jungle of Central Africa. It takes but a couple of weeks of turbine and locomotive to transport us from quiet English fields to the rolling prairie, the limitless veldt, the bleak steppes, or the inexorable desert. Arrived at those scenes, which we have known hitherto only in our boyhood's books of adventure, we shall find the animals worthy of their setting. In place of the badger and weasel, we are confronted with the ponderous elephant and rhinoceros, the savage lion and tiger, the broad-antlered moose and graceful antelopes, heavy and treacherous wild cattle; in fact, with all manner of beasts, birds, and reptiles, great and small, fierce or timorous, harmless or venomous. 
An attempt is made in the present chapter to give some account of the habits and appearance of some of the most interesting, preference being given to those which the sportsman is most likely to encounter, either accidentally or of set purpose, in the wilds of India, Africa, Canada and other regions to which Englishmen commonly emigrate. This exile to foreign parts is usually looked upon as the penalty of the younger sons; yet those who have travelled far and wide, shooting or fishing, or merely keeping their eyes and ears open to gather what impressions they may, find themselves pitying not so much the younger sons compelled to see the world as the eldest son privileged to stay at home.

The first chapter of this book endeavoured to give some sort of picture of the wild places, no easy task to one whose pen fails when called upon to reproduce the wonders he has seen. We have now to consider the creatures which inhabit these solitudes, and we must, before all, try to keep a sense of proportion, for when we lose that we lose also all hold on the realities of life. Goldsmith, the poet, once dared to twit the great Dr. Johnson by saying that, if he had tried to write a dialogue between little fishes, he would have made them talk like whales. In a book that finds something to say of both, every attempt has been 
made not to let the rats talk like the elephants, but to keep each in its right place is not as easy as perhaps it looks. Another difficulty is to show the animals in their wild surroundings, and not as they are in the Zoological Gardens or Natural History Museum. I can assure the reader, from experience, that an old moose suddenly raising its immense and hideous face from the lily-pads, as a canoe shoots silently round the bend of a river and almost to its feet, looks not less than twenty feet high, as it dashes off into the forest with a crash like that of an avalanche. I can say this, for I have sat in that canoe. It is also important to guard against deceptive impressions formed under unusual conditions. There are, as a case in point, Indian birds gifted with voices which, though not perhaps equal to the nightingale's best, are by no means unpleasant when heard in an aviary, for the listener can go away when he has had enough. It is a very different matter for Anglo-Indians compelled to listen to these noisy fowl day after day as they lie sweltering in their hammocks, goaded by the heat and irritation of exile in the East; and it is hardly surprising that they should have dubbed one of the most familiar of these unconscious offenders the "brain-fever bird." 


\section{INDIA}

Even were it not supremely interesting for the size, variety and abundance of its big game, India would surely be entitled to the first place in any English account of the creatures of the jungle, since it is to India that the vast majority of Englishmen turn for a career-military, civil, or mercantile-after finishing their education at home. Thanks partly to the religious objection entertained by many of the natives for taking life in any form, and partly to wise game laws enforced of recent years by the British rulers of the country, the wild animals have survived in India as in no other region so densely populated.

The extent to which Indian wild animals have survived in the midst of a civilisation thousands of years old is really remarkable, though it is a fact with which we have grown so familiar that we do not always appreciate its significance in the relations between wild creatures and the natives, looking on such episodes as no more extraordinary than if they happened in newly developed districts of British East Africa, which, down to a few years ago, were unreclaimed wilderness. The following is a case in point.

Early in the present year (1912) a full-grown panther, prowling on a much-used line in Berar, 


\section{THE WILDERNESS AND JUNGLE}

got caught in the cow-catcher of a passenger train. The driver stopped the locomotive, but the brute would not, or could not, descend from its awkward position. One of the passengers then climbed over and emptied five chambers of a revolver into the panther, which, however, merely snarled with rage, but still did not leave the train. Then someone fetched an iron bar, which was likewise ineffectual. There was nothing for it but to proceed, and when the train had gone a short distance the panther got clear. It was tracked and shot next day, and it was found to have all five revolver bullets in it and to have lost one of his paws. This shows remarkable vitality, but what is still more singular is the fact of the animal having stayed on the line to be caught up in this fashion. Was it a case of fearlessness or panic?

Those with a liking for natural history or sport, or, better still, for both, could hardly have their lines cast in more pleasant places. The opportunities of exciting adventure with dangerous game, or the milder pleasure of scraping acquaintance with the most attractive bird population to be found anywhere in the world, more than compensate for the drawbacks of exile in a trying climate, and I never yet heard a sportsman grumble of the years he spent in India. If he grumbled, 
it was after returning home, coming back to a land that had forgotten him and that offered the best of its sport only to those with deep purses. Interesting as are the smaller children of the jungle to the naturalist, very little is said of them in these pages, and there is only incidental mention of Indian birds, which include the grotesque hornbills, the tuneful sunbirds, the gorgeous peacock, dancing adjutant, and hideous vulture. Indian birds are, thanks to the native practice of leaving them in peace, singularly fearless and may therefore be studied more easily than the feathered folk of some other countries in which, alas! man has been the enemy and not the friend, and those who want a really interesting handbook by way of introduction cannot do better than procure a copy of Mr. Douglas Dewar's Fungle Folk, in which the author gives a most amusing account of his Indian friends. It is as enjoyable a book on birds as any I remember reading. We are here concerned rather with the elephant and tiger, with rhinoceros and buffalo in the long grass of the lowlands, with the cunning "bison," trusting sambur, and fighting wild boar that live in the cool forest glades, with the graceful blackbuck that scour the plains, with the black and brown bears of the foothills, and with the magnificent Himalayan wild sheep and goats, whose branching 
horns sportsmen seek in the eternal snows of the mountain-tops and value above all other trophies of the chase, if only because so much more time and toil have gone to their winning. It cannot be said that sport in India is as good as it was in the old days. Wild animals are scarcer, and wild tourists are more plentiful. Yet good sport is still to be had for those who will take the trouble to look for it, and sportsmanship is better and cleaner in India than anywhere else out of England. The pot-hunting that goes on in Africa, in spite of the vigilance of game-wardens, would be an impossibility in a densely populated, wellgoverned land like India, where, to give only one reason for the difference, there are no ivory-hunters, native or European. Of American sport I say nothing. Americans like my friend Mr. Hornaday, superintendent of the Bronx Animal Park, have said enough and to spare, and the scarcity of wild animals in the United States speaks for itself. Compare the condition of big game in India with that of the United States which, with, roughly, twice the area, have not one third of the population. Yet, save in a few outlying districts and Government Reservations, the land is all but denuded of its wild animals. With India we may bracket the neighbouring countries of Ladak and Tibet, as well as the island of 
Ceylon, which, while possessing many large animals in common with the mainland, has no tiger, no rhinoceros and no brown bear.

The immense numbers of wild animals in India survive even the slaughter encouraged by Government for the purpose of saving human life in the jungle. Even with such precautions, the death-rate of natives killed by wild animals is terrible, and in rolo alone no fewer than 2400 are officially recorded as having perished in this way. People in India declare that many of these so-called deaths from wild beasts are the work of poisoners, but we must remember the great difficulty of getting reliable evidence, even on oath, in communities that do not set a very high value on truth ; and wild beasts may occasionally furnish a convenient explanation of tragedies wrapped in mystery. In the same year, it may be mentioned, the death-roll among wild beasts in the official records included 142 I tigers, 5029 leopards, 2292 bears, and over 90,000 deadly snakes. With an annual slaughter on such a scale, it seems surprising that there should be any wild animals left in India at all.

\section{THE INDIAN ELEPHANT}

The elephant is the greatest of Indian animals. Clever people, who like a little Latin with their natural history, call it maxi- 


\section{THE WILDERNESS AND JUNGLE}

mus (i.e. biggest), which is interesting, but wrong, for the African elephant, which, as will presently be seen, is different from its Indian cousin in many other respects, is also much the larger and heavier of the two. Still, the clever people say maximus, and there's an end of it. Yet even the Indian elephant is no pigmy, for specimens have been known to measure eleven feet at the shoulder. In case you should ever want to know the height of a tame elephant when there is no ladder handy, it is useful to remember that twice the circumference of the forefoot gives the animal's height within an inch or two. I have tested this more than once, and it is at once simpler and more accurate than the American formula for reckoning the weight of the big fish called tarpon with a tape measure. I mention this only for the sake of comparison. The formula itself is a nightmare. The forefoot of the elephant has five nails, and the hindfoot only four.

The most conspicuous possessions of the elephant are its trunk and its tusks. The only difference is that, whereas every elephant has a trunk, many, both male and female, are without tusks, and the tusks of the female are, if present at all, generally short and insignificantlooking. The elephant's trunk is, without a doubt, the most wonderful limb, or organ, in all nature, a kind of nose and arm in one. 
That of the Indian elephant has a sort of finger at the tip, and there are two of these "fingers" in the trunk of the African kind. With the help of the finger, the Indian elephant is able to pick up all but the smallest articles off the ground, and those still smaller, such as grains of maize, are simply sucked into the trunk. So that the trunk is not merely a nose and an arm, but also a natural vacuum-cleaner, which takes trifles off the ground much as the cleaner going over a dusty drugget. Nature turns out curious noses, particularly in the birds, which, so to speak, have their nose and mouth in one, as well as in some of the fishes, which also combine the two, but I doubt whether there is such another combination tool as the elephant's trunk. It even serves as a powerful weapon now and then, for, though they do not commonly put this sensitive organ to such violent uses, elephants have been known, as will be shown in an anecdote on a later page, to seize men in their trunk and to fling them to the ground. At the same time, some of the artists who flourished in the simple days when cameras had not yet recorded the facts used to allow their imagination to run away with them, and represented infuriated elephants flinging hapless men about like so many golf balls. That is what elephants do only in books. Indeed, the trunk is usually 


\section{THE WILDERNESS AND JUNGLE}

spared unnecessary strain, and the Government elephants in the Burmese teak forests, rolling and stacking logs with infinite patience and wonderful judgment, use the trunk, as a rule, only in steadying each log on their tusks. Why, indeed, should the elephant hurt his trunk when it is so easy to gore or trample his little enemy, man? That great hunter, F. C. Selous, was once knocked off his frightened horse by a wounded elephant, which then stood over him, where he lay helpless, and drove its tusks into the earth close to his body, one of the most extraordinary escapes on record. "Charlie," a tame elephant at the Crystal Palace some years ago, was teased by a man with a spear and just trod the man to death and went quietly back to his quarters. For this "Charlie" was executed, which may have been the proper penalty for taking the law into his own feet, but which seemed hard lines, all the same. One would not have thought a mere spear could do much against an elephant's hide. Elephants have been executed in India also for this offence, and I remember hearing of a case at Mhow. The culprit was a hundred years old, and several rajahs wished to ransom him, but he had killed many natives, so the authorities would not hear of reprieve. In hot weather, or when persecuted by flies, elephants stand 
in water and use their trunk to squirt it over their backs. I have watched this performance on hot evenings with feelings of envy, for the flies troubled me also, and such a shower bath must have been very refreshing.

The tusks of the elephant are true teeth in the upper jaw. It should be remembered that they are quite distinct from the horn of the rhinoceros, or even from the tushes of the wild boar. The baby elephant has "milk-tusks" just as we ourselves have "first" teeth. How long the tusks go on growing, no one seems to know for certain, though the theory in India is that they do so all through the animal's life. As an elephant may live considerably more than a century, this kind of statement must be taken on trust, unless, of course, the yearly measurements of the tusks were handed on from father to son, which has not hitherto been done, but it seems inconceivable that this continuous growth should be the case, as in even middle-aged Indian elephants tusks have been recorded measuring nearly io feet and weighing over roo lbs. Such figures, however, were always unusual, and to-day they would be very rare. Even in Africa, where single tusks have been taken weighing more than $150 \mathrm{lbs}$., most of the best have long since been made into billiard balls and brush handles. The tusks of the cow elephant in India are small. There 


\section{THE WILDERNESS AND JUNGLE}

are also many males without tusks at all, and in Ceylon, indeed, tuskers, though not uncommon formerly, are nowadays the exception.

The appearance of the Indian elephant is familiar to most of us. In colour, the skin is black and nearly hairless, though there are bristles on the tail. The tail itself is not decorative, and sometimes it is much disfigured. One historic "rogue" elephant, shot some years ago in the Bangalore Ghats, was minus half of its tail, and the natives say that this is done in fighting other elephants. They must therefore bite their antagonist's tail off, though they must surely have some difficulty in getting hold of such a wretched little object. In Burmah there are so-called "white" elephants. These are not in reality white at all, but a dirty flesh colour. Still, they have been called white for so many years that tourists in the Far East are bitterly disappointed not to find them as white as Polar bears. I suggested above that an ordinary spear should make very little impression on the elephant's hide, but I ought to have remembered the misery these huge creatures endure from biting flies, to escape from which they not only stand for hours up to their eyes in muddy water, with only the tip of the trunk above the surface, but also clamber far up into the hills, being better climbers than one would think possible of such 
monsters. It must not be supposed that escape from their insect tormentors is the only purpose which prompts elephants to migrate to the mountains, for they also climb to great heights in search of suitable food when supplies fail them at the lower levels, but they certainly make shorter journeys above the plains when the flies are most troublesome. When, choosing the other alternative, they seek a water cure, they are sometimes unable to find depth enough to submerge animals of their height, and at such times they squirt the water out of their trunks, as mentioned above, and plaster themselves over with mud. This makes them look disgusting objects, but it certainly gives them peace from the tsetse and other venomous flies on the look out to suck their blood, and I am not sure that those who fish on Canadian rivers in summer, and suffer torments from the blackflies and midges, might not follow the elephant's example and plaster a little mud on their face and hands. Such an experiment might be worth trying, at any rate when the "dope" has given out.

With its immense body, long and tapering trunk, curling tusks and straight, massive legs, the elephant is an extraordinary creature, different in size and shape from any other in

${ }^{1}$ A chemical preparation sold for bathing the face and hands and keeping biting flies at a distance. 


\section{THE WILDERNESS AND JUNGLE}

existence, though a pigmy compared with some of the mammoths that once roamed the frozen steppes of Siberia. I have seen the remains of one of these in the Natural History Museum at St. Petersburg. It could not, in life, have been a large specimen, but, with the hairy skin, it must have been an uncouth object and much more terrifying in appearance than even the elephants of our day.

The senses of the elephant are much as those of other wild animals. It relies chiefly on its scent, and the trunk tells it of the approach of the enemy more often than either its wicked little short-sighted eyes or even the huge ears, which, in the African kind, are simply enormous, but which are also, in many elephants, quite incapable of hearing. It is curious, indeed, that the largest ears in all creation should belong to an animal that is almost deaf, but it is a fact. The sense of smell, on the other hand, is wonderful, and the sportsman stalking a wild elephant has to exercise the greatest caution, as, if the wind should suddenly shift, blowing from him to the animal, it will at once smell him and either bolt away in to the jungle or charge outright.

The cow elephant is devoted to her young one, and always ready to put herself between it and danger. It must be confessed, on the other hand, that my lord, the elephant, puts the 
safety of his own skin before every other consideration. When a herd gallops out of danger, the bulls manfully lead the way, leaving the rest of the family to do as best they can. Yet even in this sauve qui peut the females never desert their calves. In fairness to the males, we should perhaps admit that they may realise, either from experience or by hearsay (who knows, after all, what tales they may tell each other?), that they, and not their wives or children, are the chief object of the sportsman, though ivory-hunters in Africa make little or no difference between them, shooting all and sundry with marketable tusks.

The daily life of a herd of elephants varies according to the season of the year. In the rains-I speak, of course, of the Indian elephant-they climb into the hills, glad to get out of the valleys, which are then alive with flies. They are always on the move, be the weather wet or dry, for it will easily be realised that creatures of such immense size and such hearty appetite soon exhaust the food supply, and in order to get sufficient juicy grasses, tender stems of young bamboo, and wild plantains to stay their hunger, they must travel far, crashing their way through the jungle, ripping off great strips of bark with their tusks, digging up trees by the roots, trampling down shrubs, spreading havoc and ruin in the 


\section{THE WILDERNESS AND JUNGLE}

ryot's crops and gardens, spoiling whole plantations of tea and coffee, pulverising the native huts, and doing terrific damage, much of it in aimless frolic. In the heat of the day they rest beneath some clump of banyan trees or in other shade, ears flapping, bodies swaying, first one foot and then the other being lifted off the ground. At the hottest time of the year they seek shelter in some forest of evergreens, and when asleep they do not, as some artists still prefer to picture them, lean against the trunks of trees, but lie on their sides like men and horses and many other tired animals, both wild and tame. We have got so accustomed to these elephants leaning against trees that I almost hesitate to destroy belief in the habit, but it is best to have the truth, even though it be less picturesque than fiction.

For all its great size and colossal strength, the Indian elephant has an abject fear of man, and, considering what a puny figure of a man the average mahout, or driver, is, this docile submission says a good deal for the thoroughness with which the natives of India have tamed these giants. Of this more will be said in a later chapter. The readiness with which wild elephants caught in keddahs are, with the help of tame ones, reduced to obedience is extraordinary. It is ludicrous to watch one of these tremendous brutes taking its punishment 
CREATURES OF THE WILDERNESS 6I

meekly from some little undersized native whom, if it but knew its strength, it could crush as we crush a wasp. That is the elephant subdued by man. Yet a wounded wild elephant at close quarters is a terrible adversary, and a solitary "rogue" (or gunda) will terrorise a whole district for weeks together, so that the woodmen are afraid to go far into the jungle and the villagers are held up as if undergoing a siege. Not every lonely elephant, it should be remembered, is a "rogue," for the tuskless males (or maknas) are at times so bullied by their more fortunate brothers with tusks that they prefer, though not necessarily vicious, to separate themselves from the herd and lead a solitary existence.

How and why an elephant turns "rogue" is an interesting question that is always being argued, but rarely answered in a satisfactory manner. Clearly his case is not on all fours with that of the man-eating tiger, which we shall discuss later. Nor must permanent roguery be confused with the passing madness known in India as must, under the influence of which one of these animals will sometimes run amok, as it is called, in the bazaars, killing all who do not get out of its way. There is an even worse type of elephant than the wild "rogue," and that is a once tame elephant that, impatient of its bondage, has escaped back to the jungle. Such 


\section{THE WILDERNESS AND JUNGLE}

an elephant at large is a dreadful fellow, for, like the house cat that takes to poaching in the woods at home, it is far more cunning than its wild cousins and is moreover indifferent to man, since in this case familiarity seems to have bred contempt. The only cure for such is a rifle bullet through the brain. As to the making of "rogue" elephants, no one knows exactly how this comes about, though many causes have been suggested. My own idea, which I offer only for what it may be worth, is that bad shooting may have had something to do with it. This theory may, at first sight, look rather far-fetched, but let me explain my meaning. We know, from accounts furnished by former travellers on the White Nile and other inland waters, both river and lake, of Central Africa, that the hippopotamus was in those days a more peaceful, fearless and frolicsome creature than it is nowadays, when trippers have invaded those regions and have taken to the curious pastime of pumping lead into every hippopotamus that comes to the surface to breathe within range of their guns. This is a disgraceful practice and one that should be severely dealt with. Unfortunately, these holiday "sportsmen" regard the wilderness as their own, and, not satisfied with desecrating its sanctuary with their uncouth presence, they must needs slaughter every 
creature that comes within their reach. What is the result? Simply, as might be expected, that the once inoffensive hippopotamus, smarting from its wounds (since these miserable marksmen rarely kill outright), has lost its temper, which is hardly surprising.

Many of the aggressive acts on the part of the hippopotamus arise, in Sir Henry SetonKarr's opinion, from the mother's anxiety to protect her calf. The wooded islands above the Victoria Falls have long served as a hipponursery, and the mothers apparently resent the presence of canoes.

My reason for supposing that some such grievance may have had its share in the manufacture of "rogues" is that, with very rare exceptions, elephants reveal, when cut up, the wounds and even bullets of former encounters with man. This is why I regard bad marksmanship as a possible factor in having soured their tempers and driven them to brood over their troubles in a solitude that only makes them more morose and anxious to avenge themselves on those that persecute them. Now, there is an objection to this suggestion of mine which, in fairness, I must not overlook. The truth is that, save in such jungles as those of Mysore and Travancore, the native rulers of which give occasional permission to distinguished guests to shoot an elephant, these animals 


\section{THE WILDERNESS AND JUNGLE}

have not been shot in India for many years. Yet, as we know that elephants live for a hundred years or more, and as "rogues" are rarely in their first youth when shot, this objection does not seem insuperable. Some doubt exists on the question of whether the "rogue" elephant is bodily expelled from the herd in the first instance, and the episode has never been actually witnessed, or has, at any rate, not been described by anyone who pretends to have seen it. It is, however, well known that "rogues" often try to rejoin the polite society of their kind, but that they are not readmitted to the community, being regarded by their fellows as outcasts for life. General Hutchinson's view of the "rogue" is that he has become solitary and morose because no longer attractive to the females, and is, so to speak, cut out by the younger generation.

Of the mind of the elephant we know, as in the case of other animals, less than we do of its body. There is, in fact, considerable difference of opinion as to whether it should be regarded as clever or stupid. Some even of those who know it in its own home look with grave doubt on the many stories told of its marvellous intelligence as gross exaggeration. They point, in support of their less flattering opinion, to the small size of its brain and to the readiness with which it allows itsclf 
CREATURES OF THE WILDERNESS 65 to be caught in keddahs or pitfalls. Yet even men occasionally fall into the latter, and I imagine that, in elephants as in ourselves, there are differences and that one may be more intelligent than its fellows. Two of the most striking proofs of the cleverness of some elephants that I remember reading were communicated to the Field by Mr. C. W. A. Bruce, a Forest Officer in Burma. Mr. Bruce often watched one of them break off a branch and use it in its trunk to scratch some part of its back or sides otherwise out of reach. Still more remarkable was the behaviour of a runaway female that escaped, dragging her chain. No sooner did her attendant give chase than she promptly seized the loose end of the chain in her trunk, clearly with the twofold object of saving herself from tripping over it and of preventing the man from catching hold of it. It is impossible to attribute any less intelligent reason to her action, and, if this was not clever, I should like to know what is.

I am much indebted to that distinguished sportsman, Sir William Lee-Warner, G.c.s.I., for the following interesting notes on sagacity and memory in elephants. After reading what he has to say, it is not easy to entertain any reasonable doubt of the cleverness which these animals sometimes display, and if, on other occasions, they seem to fall short of what we 


\section{THE WILDERNESS AND JUNGLE}

should have expected of them, it is always fair to remember that we may possibly misinterpret their motives and overlook reasons for their conduct which, though not always apparent from our limited point of view, may appear perfectly sound to them. I give the evidence in his own words :

"In the cold weather of 1870 , I was camped out in the District of Nasik, in the Bombay Presidency. At that time, the military department maintained a number of elephants, some of which were employed on what may be called civil duties, such as the clearance of forests, the destruction of wild beasts, ceremonial occasions of a political character, and so forth. A certain contingent of elephants had, on the occasion of Lord Mayo's visit to Ajmer, or some similar function, to be sent north. Three elephants, one from Ahmednagar, a second from Khandesh, and a third from Poona, were to meet near my place of encampment and to march in company to their appointed station. On the arrival of the Khandesh elephant, which had recently been employed in tigerkilling operations, it was at once noticed that something was seriously wrong. The animal was clearly ill at ease. Next morning when one mahout had mounted his elephant, and another was about to mount the second, the Khandesh elephant suddenly broke loose before being mounted, roughly pushed away his neighbour, and, taking the mahout in his 


\section{CREATURES OF THE WILDERNESS 67}

trunk, knocked the man's head against the ground, after which he tossed the body from his forearm to his hind leg and stamped the life out of his victim. Meanwhile his own mahout promptly mounted the elephant whose mahout had been killed and, with the third elephant and mahout, hurried away a distance of a few hundred yards and then halted to see what would happen. What did happen, to the surprise of everyone, was that the riderless elephant came up as quietly and meekly as possible, and when his own mahout spoke to him from the neck of the animal he was riding, he readily obeyed the customary words of command. So he descended, and his own elephant assisted him to mount, as usual, showing that the fit of rage was over. Such extraordinary conduct on this occasion was subsequently explained by the records of the dead mahout's service. He had taken this Khandesh elephant to the Abyssinian War, in $\mathbf{1 8 6 7}$, and from that campaign the poor brute returned in a terrible condition and covered with sores. The mahout, on getting back to India, was given leave and was subsequently given charge of another elephant at a distant station, never again meeting with the animal he had ill-treated until this affair in 1870 . He had forgotten the elephant, no doubt, but the elephant had neither forgotten the discomforts of the Abyssinian service nor forgiven the author of them.

"Another remarkable instance of the sagacity of elephants came under my notice in Mysore in 1905, when Lord Elgin was going to 


\section{THE WILDERNESS AND JUNGLE}

witness a Khedah, in which wild elephants are driven into a series of stockades. Sir Sheshadri Ayer, the Minister, was remarking on the comparative failure of the present Indian head of the Khedah establishment as contrasted with the success formerly achieved in that position by G. P. Sanderson. It appeared that the Indian director, inspired by humanitarian motives, avoided the destruction of any elephant that was seen turning back or escaping from a stockade. Sanderson, on the other hand, used invariably to shoot all such, on the sound principle that dead men tell no tales. That his view was in all probability the correct one is sufficiently proved by an incident that was related to me on this occasion. A fair number of elephants had been driven right up to the outer stockade, and one or two had entered by the concealed gate. Suddenly a fine tusker advanced to the gateway and took up his position under the suspended gate, where he proceeded to resist the entrance of other elephants, beating them off for a considerable time and finally leading them in a wild rush that broke the line of beaters. Then someone present remembered that on a previous occasion an elephant, apparently the same one, had escaped from the outer stockade, and it seemed reasonable to assume that the intelligent animal had remembered and used his experience so as to prevent others from falling into the same trap.

"A step further is reached when an elephant reasons not from experience, but from fore- 
sight. I once saw an elephant in Canada engaged in intercepting the logs and trunks of trees that were floating down a river and stacking them on the bank. The precision with which the logs were laid, and the ingenuity with which, as the stack rose in elevation, logs were rolled up an incline made by the elephant for the purpose, were remarkable. But the feat that astounded me most was when the elephant, while dragging a tree out of the swift stream in his trunk, suddenly observed another log coming downstream so rapidly that it must inevitably have swung out of reach before he had time to deposit his burden on the bank. In an instant the animal pushed the descending $\log$, with his foot out of the rapid current, slightly upstream, and so into the slack water under the bank; after which, quickly depositing the tree on land, he caught up the $\log$ with his free trunk before it could sweep past him.

"It seems, however, that there are times, particularly when they have done wrong and are ashamed of themselves, when elephants lose their heads. A mahout, passing through Sangli in 1886 , went into a cottage and set a child in his own place on the elephant's neck. The elephant resented this pleasantry, killed the child, and made off. The villagers raised a hue-and-cry just as I happened to be riding through the place, and some police with fixed bayonets were hastily collected and marched with slow and regular step to where the animal stood. The elephant backed slowly until it reached the stump of a tree, where heel-chains 


\section{7o THE WILDERNESS AND JUNGLE}

and other fetters had been prepared for it. It was then secured without offering the slightest opposition, and if it was minded to resist capture it certainly neglected an obvious precaution which experience might, one would have thought, have suggested as the obvious means of escape."

Those who give the elephant less than its due credit for intelligence will, I think, be inclined to reconsider their verdict after reading these very interesting anecdotes, which illustrate the memory, ingenuity, and remorse of which these mighty creatures are evidently capable.

I have already mentioned the fact that, ordinarily speaking, there is no longer elephant shooting to be had in India. The only chance for the sportsman in that country is to be asked to shoot a "rogue" or an elephant in must. The only fatal shot that can be relied on to kill outright is through the brain. When shooting from the front, the rifle is aimed at the ridge, or bump, midway between the eyes ; but in shooting from either side it is necessary to know the exact position of the brain, which is very small in proportion to the size of the head. All manner of diagrams have in consequence been published with a view to assisting the novice in making the critical shot. What the novice invariably does, diagram or no 
CREATURES OF THE WILDERNESS $7 \mathrm{I}$

diagram, is to empty the contents of his rifle all over the elephant's surface and to send it off screaming. There is not much time to lose, for if the wounded brute does not hurry out of range it will charge in the opposite direction, in which case the sportsman usually moves off the scene without further deliberation. A charging elephant comes on at a surprising pace, trunk curled high in the air, little eyes gleaming, great ears flapping, altogether a tremendous picture of rage and strength. The obstinate bravery of elephants fighting against odds is never more grandly or more pathetically illustrated than in their not infrequent encounters with railway trains. The fate of "Jumbo," who met his death in this way at a time when his weight exceeded six tons, will long be remembered in England, where he had been made the hero of somewhat hysterical sentiment on the occasion of his sale to an American showman.

Collisions of the sort between trains and elephants are not uncommon in India, and in the Malay Peninsula they were at one time of constant occurrence. On one occasion, the driver of a goods train, seeing a big tusker on the line ahead, first slowed down and then stopped his train altogether. Even this deference to his majesty did not satisfy the elephant, which at once charged the engine, dashing at 


\section{THE WILDERNESS AND JUNGLE}

it again and again with terrific force and doing considerable damage. Each time the driver made an attempt to continue the journey, the enraged elephant charged with new fury, and the man hesitated to go full speed ahead for fear of derailing his train. At length, though not until after his head had been severely battered, the elephant tried other tactics and charged backwards. As a passenger train was due to follow, the driver felt that no more time must be lost, so he let his engine go. One of the wheels went over the elephant's leg, putting him out of action, and he was subsequently shot dead by the guard of the train that followed.

Such is the Indian elephant. For all its occasional roguery, its fits of must, and of rage as blind and stupid as that just narrated, I always like to think of it as by far the most impressive of living animals, the type of a massive dignity that should command the respect of little folk like ourselves, even though we have tamed it and invented rifles with which to destroy it. This is why, quite apart from the possible, not to say probable, cruelty involved in the training, I dislike seeing circus elephants made to stand on their hind legs and beat drums. Such foolish tricks should be taught to animals of less dignity, and I would almost as soon have contemplated the late 
CREATURES OF THE WILDERNESS 73 Mr. Gladstone dancing a breakdown in the Monkey House at the Zoo.

\section{THE RHINOCEROS}

We know all manner of rhinoceroses best by the horn, or horns, on their snout. There are three different kinds of these animals in Asia and two in Africa, but as this chapter does not pretend to describe every animal, the so-called "great" rhinoceros of Assam, Kooch Behar and Nepal may do duty for the Eastern species. It is a huge, blundering creature, standing about six feet high and carrying on its nose a single pointed horn a foot or more in length. The so-called "horn" of the rhinoceros is absolutely different from those of goats or cattle, being really a growth of hardened skin. It can, in fact, be removed without leaving more than a scar, which rapidly heals, and this actually happens to these animals in captivity, for they occasionally rub off their horns against the bars. Both sexes carry this formidable weapon, but, as a matter of fact, the Indian rhinoceros fights only with its teeth, the horn being used only in tearing up roots. So long as they are not molested, these animals are usually inoffensive, and when they have been known to charge without provocation, it has been a case 


\section{THE WILDERNESS AND JUNGLE}

of nerves. They are short-sighted and hard of hearing, and when they suddenly get wind of a man they are apt to charge blindly, for fear of being surrounded. In parts of India, the high grass is both board and lodging to the rhinoceros, which lives in it and feeds on it, and must, therefore, be shot from elephantback, as it is not possible for anyone on foot to get a shot. The rhinoceros of Sumatra is a smaller animal, with hairy ears. It is not particularly courageous, but is very destructive in the plantations.

\section{THE WILD BOAR}

This animal is the joy of Indian sportsmen, particularly of soldiers stationed in that land, who find pigsticking one of their favourite amusements. Nowhere else do boars show such fight. I have seen them pretty nasty when maddened by spear-thrusts in the corkwoods near Tangier, but an old Indian boar, which stands some thirty inches at the shoulder, is the incarnation of pluck, tushes bristling, little red eyes flashing, charging times and again, even with spears broken in its body. Though considered a dainty by both tigers and leopards, and, doubtless aware of their fondness for his flesh, the boar thinks little of drinking at the same waterhole as 


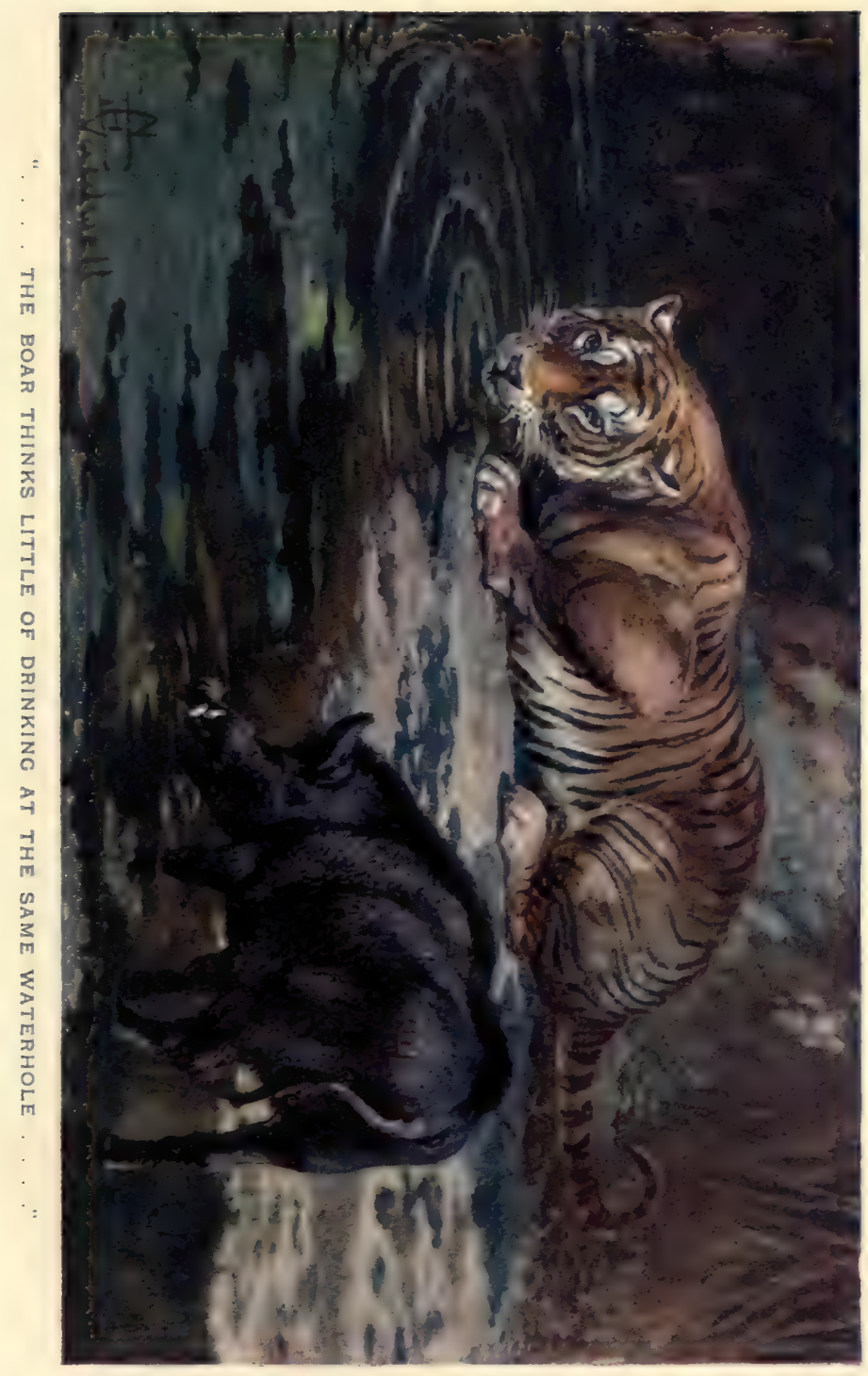



they, and these creatures must be hungry indeed to molest him.

I am indebted to a well-known sportsman for a remarkable illustration of the dread in which the wild boar is held by even the fiercest animals in the best of condition. There are people who disbelieve the accounts of how the pig will drink unconcernedly at a pool with tigers standing by, but the following experience leaves no shadow of doubt of its superiority in courage to, at any rate, a panther:-

My informant was shooting in the Kinwet Reserve, Berars (N.W. of the Nizam's Dominions), in the month of May, rgo6. On this particular occasion he was seated in a machan in a solitary tree overlooking the Doderi Nullah, a boulder-strewn watercourse. A buffalo calf had been tied up as bait for the notorious Gari tiger, an immense lightcoloured and very cunning old tiger that had been known for more than ten years to the officers of Gordon's Horse, but had never got caught in a beat. Even his pug-marks were well known, being distinguishable not alone by their great size, but also by the peculiarity of the near fore-paw being turned slightly inwards.

This gentleman has no high opinion of the practice of shooting tigers at night from a 


\section{THE WILDERNESS AND JUNGLE}

machan, but admits that, in the case of hardened man-eaters or cattle-slayers, it is the one and only method offering any reasonable prospect of success.

The redoubtable shikari Dafadar Taman Sing, of Gordon's Horse, had installed him at an early hour in his machan, and for two hours he had kept silent vigil. Nothing was moving in the vicinity of the unsuspecting boda until about seven in the evening. Then, just as the sun was going down under the horizon, a big, solitary old boar came into view a quarter of a mile away, feeding quietly as he moved from point to point, and little by little approaching the watercourse, which at that point would have been some two hundred yards wide. Finally the boar came within twenty yards on the leeward side of the calf. Then something quite unexpected happened. To the horror of the watcher overhead, the boar faced towards the calf and, with a series of defiant grunts, showed every sign of charging across the intervening boulders. It looked as if a tragedy was about to be enacted, and my correspondent, supposing that the boar had scented the calf and mistaken it for an enemy, looked round in the direction of the bait. Then he saw the meaning of the boar's hitherto puzzling behaviour. There lay a large panther, which had so far contrived to keep out of sight 


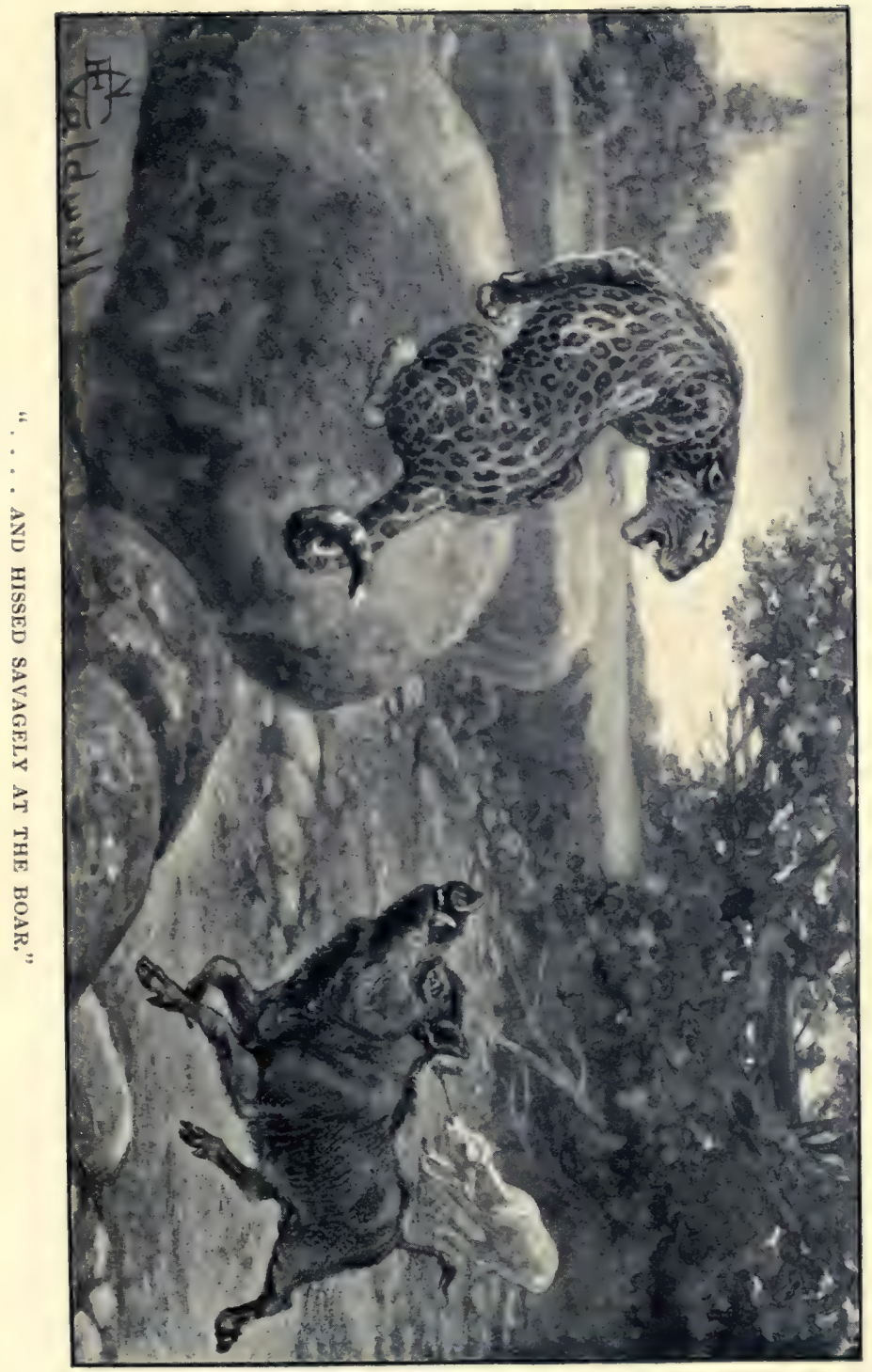



CREATURES OF THE WILDERNESS 77 and which, having stalked to within a few feet of the calf, was only waiting for the darkness that would precede the rising of the moon in order to make a meal of it.

A battle between these warriors of the jungle seemed imminent, but the panther was not equal to it. It squirmed its way to the top of a boulder and hissed savagely at the boar, but that was all ; and it was just turning to make off, in spite of the fact that the ground was of a nature to have given it the advantage, when a shot from the 8-bore in the machan rolled it over on the far side of the boulder. The boar apparently took in the situation at a glance and, after one triumphal snort, tripped contentedly away.

A thunderstorm broke during the night, which gave the watcher the agreeable choice between remaining in his tree and taking his chance with the lightning, or descending to earth and chancing a collision with the Gari tiger.

Next morning he visited, with proper caution, the spot at which he had last seen the panther, but it lay dead on the further side, and death had evidently been instantaneous. Its length, native measurement (i.e. liberally stretched), was $9 \mathrm{ft} .3_{2}^{\frac{1}{2}}$ in. In any case, it was a large specimen, and as it was in excellent condition, such pusillanimous conduct, even in face of a boar, seems inexcusable. 


\section{THE WILDERNESS AND JUNGLE}

Indeed, there are stories enough of the Indian boar's pluck and vitality to fill a book by themselves, though none perhaps more significant than one told in an old book of a boar and tiger being found dead side by side. As an illustration of the strength and vitality of these die-hards, the following story has struck me as remarkable. A sportsman came suddenly on an old boar in the jungle and took a snapshot, hitting it too far back. (It should be mentioned that it is etiquette in British India to shoot boars only in jungle-country where they cannot be ridden after.) The animal at once charged, and in such a desperate hurry that the man had no time to reload, but instinctively held his rifle, a heavy weapon, crosswise before him to take the shock of the charge. The boar took the narrow neck of the weapon, near the trigger, between its teeth and bit clean through it. Then it knocked the sportsman over and started ripping him with its tusks, but it was too badly hurt itself to do much damage, and soon went a little distance and sat down, breathing heavily, and evidently in a bad way. This encounter took place towards sunset quite near the sportsman's bungalow, and to this he now managed to crawl without the boar showing further fight. Next morning he went in search of it, taking another rifle for safety's sake, though fully expecting to find a dead 
CREATURES OF THE WILDERNESS 79

boar. What he found was a very lively boar, in the same spot where he had left it, that actually charged him again with great fury. This time, however, he finished it off. Few other animals could lie up severely wounded for a whole night and then charge, apparently as fresh as ever, next day. Colonel Williamson tells me that he once had a lucky shot at a boar, which he could only see indistinctly in a clump of so-called wild arrowroot. On this occasion also the bullet struck it too far back to do mortal injury, and out it came straight for him. The Colonel took a hurried shot at close range, and then, catching his feet in some roots, fell on his back, expecting every moment that the boar would be on him and would score his body with some of those L-shaped gashes that the tusks always make. As he jumped up he found the animal lying dead at his feet, the shot having penetrated to the brain just over the left eye.

Like many other really brave animals, the boar is no bully. Leave him alone, and he will give you the path. I recollect riding one moonlight night right up to an old boar, with his sow and his litter, and the pigs, which were digging up truffles or some other delicacy when I came suddenly upon them, just galloped back to the hills, the old gentleman covering their retreat. An elephant, on 
8o THE WILDERNESS AND JUNGLE

the other hand, would have shown the way. A wild boar strikes one as about the last creature on earth to make a pet of, but I remember hearing of a lady in India who brought up a small wild sow that became much attached to its owner. The adopted one even slept under her bed and did quite as well as a watch-dog, rushing at all intruders. It used also to go out with the dogs when the sahib went shooting, and was invariably first on a dead bird. There was, indeed, only one slight drawback to the value of this otherwise admirable pointer, and that was that it always ate the bird before the sahib could get to it.

[The plan on which this book is written precludes any detailed account of European wild animals, but a note may be of interest on the prevalence of the wild boar, which has been extinct in Britain since the days of Queen Elizabeth, in Belgium and France. As a matter of fact, this animal roams over most of Europe, though is not apparently found in either Holland or Scandinavia. In all rideable country in India it is etiquette to kill it only with the spear, shooting it merely in ravines or in jungle where the sport of pigsticking would be out of the question. At Howara, also, near Tangier, it has for many years been killed with the spear, and I remember a Spanish 
CREATURES OF THE WILDERNESS 8I

nobleman with large estates in Spain assuring me some years ago that he fully intended preserving it for the same purpose on his property, though whether he ever carried out his intention I have never heard.

Belgium is overrun with wild boars, mostly from the Ardennes, in hard winter weather, and these audacious brutes even invade the villages round Verviers during the heavy snowstorms, seeking what they may devour. Indeed, on one occasion a farmer was charged by one in broad daylight in the streets of Jalhay; and the boar is so ruinous to Belgian farmers that it may be shot at sight without licence or hindrance. Occasionally it gives good sport when hunted with hounds. I remember an occasion on which, not far from Bievre, a falconer, who was abroad at daybreak in search of a lost hawk, came on an immense boar in a pine clearing. The boar having been located, the local pack was quickly turned out, and the boar gave them a first-rate run over the snow, through Fleurifoy and along the banks of the little river that runs past it. At length the boar got desperate and suddenly turned on the horse ridden by the Master, the Baron de Crawhez. The Baron, however, snatched his horse on one side and subsequently gave the boar the coup de grâce, though not before several of his best hounds had been killed by 
82 THE WILDERNESS AND JUNGLE

the infuriated animal. On another occasion a drove of no fewer than thirteen boars was seen in the moonlight in the outskirts of Esneux, a village in the province of Liége.

Shooting boars is not a very dangerous sport, because they do not, for all their pluck, charge unless wounded, and also because care is taken to post the guns in such safe spots that it would not much matter if they did. Still, accidents do occasionally happen, in spite of these precautions. One day the veteran Prince Regent Luitpold of Bavaria was shooting hogs, and one of his guests missed a boar. The boar did not miss him, however, but laid him on his back and so ripped his legs that he was disabled for weeks at Schloss Rohrbrunn.

The technical name for these animals in French venery is bêtes noires (which suggests blackbeetles), and there is in that country a very dangerous practice of making pitfalls to catch them in. These traps, concealed by branches, are a constant source of danger to hunting-men. Count Joseph Lahens used to keep a pack of the famous Piqu' Hardi Gascon Bâtards solely to hunt wild boars in the Landes and Gironde. These are longeared, powerful hounds, standing twenty-four inches, and they hunt the boar with wonderful scent and with a courage that almost matches its own.] 


\section{HORNED GAME}

There is great variety of horned game in India, including the ponderous "bison" and buffalo, the splendid goats and sheep in the mountains, with sambur in the forest and antelopes on the plains. Some of the mountain sheep must be endowed with enormous strength to endure life at such altitudes. Dr. Longstaff tells me that, in Tibet, he has seen burrhel up to eighteen thousand feet, and even higher, and the gradients that these creatures have to climb for their daily food are simply appalling. Of all the trophies, sportsmen most prize the spreading horns of Ovis poli and Ovis ammon, or the spiral horns of the markhor, a wild goat found in the mountains of Kashmir and Ladak. Like the burrhel, these sheep inhabit tremendous heights above sealevel, and they gallop over the rough and broken ground at an amazing pace, never seeming to miss their footing even when hotly pursued. The first two sheep grow horns measuring seventy-five inches and fifty inches respectively, and the black and twisted horns of the markhor may exceed sixty inches. This animal is found at the highest limit of the pine forests, along the edge of which its flocks graze early and late, resting during the heat of the day. This also is the way of the so- 


\section{THE WILDERNESS AND JUNGLE}

called " ibex," a beardless goat of the Nilgiris, and a ewe is always posted as sentinel while the rest of the herd feed or rest. The faithful ewe takes up a commanding position and never slumbers at her post, though how she is persuaded not to feed or lie down with the rest is one of those mysteries of animal life that we are never likely to solve. Is it done under compulsion, with all manner of pains and penalties for carelessness, or is it a labour of love?

The high places of Asia have their wild ox as well ; the famous yak, which inhabits Tibet at altitudes of fifteen thousand feet or more. Many herds, indeed, rarely descend below that level. It is found in the tame state as well as in the wild; but in Ladak, at any rate, there have been no wild yak since $\mathrm{r} 887$. How, with such miserable fare as is provided by the starved grasses of the mountain-tops, the yak manages to grow so big and strong is a problem, yet there are few wild oxen finer than this massive brute of the mountains, standing nearly six feet high, with its long black horns and hair. The yak has been domesticated for centuries, and among the eccentricities of the pure-bred animal mention may be made of a distaste for corn, which it is never able to overcome. It is less keen-sighted than most animals of the peaks, and, like the sheep and goats of the 
same lofty region, it rarely looks for trouble from above, so that sportsmen often make a long and tiring stalk so as to get above the game and fire down on it. The herd is always on the move, inspired by a restlessness which there is no difficulty in understanding when we remember how scanty Nature's larder must be at those frozen heights.

The lowland cousins of the yak are the gaur (which Anglo-Indians call "bison") and the buffalo. The "bison" likewise clambers into the teak and bamboo forests in the hills, feeding up to a height of six thousand feet. Most people are familiar with the animal, at any rate in the Zoo: a powerful black ox, with a greasylooking hide, small feet and slender whitestockinged legs, neat "breedy" head, and powerful yellow horns tipped with black. The finest of these horns measure over forty inches across. The gaur, as, with all deference to sporting nicknames, I prefer to call it, stands fully six feet at the shoulder, and is perhaps the most massive of all the wild cattle, as a big bull, in good condition, will weigh not far short of a ton. It does not love its neighbour as itself, more particularly when the neighbour is a European, but is one of the first among the wild and timid jungle-folk to desert its old haunts when these are invaded by civilisation, and to seek solitudes still more remote in which 
86 THE WILDERNESS AND JUNGLE

it can hide from the eyes (and bullets) of man. It has a remarkably keen sense of smell, and a solitary old bull will get wind of his pursuer at an almost incredible distance. If unwounded, he will take the opportunity of galloping off out of harm's way, but, if hurt, he will lie in ambush with extraordinary cunning, and for this reason the gaur is one of the most dangerous creatures to follow up in high grass, more than one sportsman having paid with his life for underrating the strength and tactics of the enemy. It even turns hunter, circling round the sportsmen as at times lions do, stalking him, in fact, and then charging with confusing suddenness from an unexpected quarter. It has also, now and then, been known to charge before a single shot is fired, but this is a risk to be feared rather by the silent, bare-footed native than by Europeans, whose substantial tread as they go through the crackling undergrowth generally advertises their approach in time for the wild creatures to make tracks, as, indeed, most of them, given the chance, are only too willing to do. The Indian buffalo, which flourishes in Assam and some neighbouring countries, is a very different looking animal, greyer in colour and almost hairless, with a wider spread of horns. Unlike the gaur, it has no fancy for the jungle, but spends most of its life in the high grass of the plains 
CREATURES OF THE WILDERNESS 87

and is very fond of wallowing in swamps and waterholes, as its splay feet are of wonderful assistance when it wants to get quickly over soft ground. This furnishes a favourite subject for heated argument as to whether the animal gradually developed splay feet because it liked walking in treacherous places, or whether, on the other hand, it took to marshes because it realised that its feet were suited to such conditions. To some extent, no doubt, such discussions show intelligence, but the questioners would show more if they did not always supply the answer according to their own fancy, and as positively as if the matter admitted of no further doubt. It is a pity to be drawn into taking up this cocksure attitude, and is far better to keep an open mind. Someone has remarked that dogmatism is puppyism grown up. Anyway, it is a vice best avoided early, or it soon grows on us. There are so many clever people in the world who know everything, that a few of us can well afford to be ignorant and own up to it. Like most wild oxen, the buffalo has amazing vitality. Unless killed outright by the first or second shot it dies very hard. Major Talbot tells me that on one occasion he saw one of these animals knocked down four times in succession, and each time it scrambled to its feet and charged again. When at length the old warrior was skinned, its body 
was found to contain no fewer than thirteen Paradox bullets, and most of these had " mushroomed" under the skin on the further side. Even experienced sportsmen have been puzzled by the unconcerned way in which some animals receive bullets in vital parts of the body. Indeed, these sometimes seem to take so little effect that beginners, who imagine that they held their rifle straight, are disheartened by the conviction that they must have missed altogether. I recollect the case of an old bull elk in Sweden, which was hit four times, after which he trotted quietly off into the forest. Yet it was afterwards discovered that two of the bullets had gone clean through the animal's brain and two through the shoulder blades!

The remaining horned game of India comprises all manner of deer and antelopes, though it is not the purpose of this book to include a full list. As examples of the deer, we may take the sambur and barasingh, while the most attractive and best known of the Indian antelopes is undoubtedly the blackbuck. The sambur, known to sportsmen in Ceylon as the " elk," is a splendid creature, though its antlers do not show the ten points of our Scotch stags, having, in fact, no more than three. As, however, the sambur's antlers may measure fifty inches, they make a beautiful trophy. The animal does not appear to shed them regularly 
every year like our European deer, but sometimes carries them for two or three seasons. All manner of explanations of this curious habit have been suggested, but no one really knows the reason. It is just guesswork. In colour, the sambur is light brown when young. The hind, indeed, retains the lighter colour throughout life, but the stag grows gradually darker, till old stags are nearly black. When angry or alarmed, this deer has a singular trick of making the hair on its back and neck stand on end, as ours is supposed to do when we see ghosts. The sambur is a child of the jungle, hating the glare of the Indian sun and hiding away all day in the cool bamboo glades. Like many other deer, it feeds up in hilly country, climbing to a height of fully eight thousand feet above sea-level. It is less suspicious than most of its tribe, and often, indeed, offers an easy shot because of the silly curiosity with which, instead of taking to its heels, it will stand and stare at the intruder. It is also less thirsty than other of the jungle-folk, and is found at times some distance from water. The majority of wild animals, on the other hand, are sought by sportsmen in the neighbourhood of river-banks and waterholes, and native hunters in both India and Africa do much damage by sitting up on moonlight nights, close to well-known drinking places, and blazing away at everything that 
90 THE WILDERNESS AND JUNGLE

comes down to the brink, killing few, but wounding many. Some people always raise an outcry whenever anything is said against allowing natives to carry arms, but, as will presently be shown, it is these armed natives who, more particularly in Africa, are chiefly responsible for the disappearance of the very animals that we aim chiefly at protecting, so as to save them from the irrevocable edict of extermination, which has already gone forth against more than one beautiful and interesting wild animal in that continent.

Colonel Williamson, several of whose varied memories of Indian sport I am privileged to relate in these pages, has often seen cases in which the well-known lack of scent in the majority of young animals has been the means of saving their lives. In support of this view, he recalled an experience with a young sambur. Accompanied by half a dozen natives from Ootacamund and their pariahs, which ran in company with his own spaniels, he had been shooting in some of the sholas (evergreen coverts which clothe the lovely ravines of the Nilgiris), and, having beaten one of them, had crossed, with the whole party of men and dogs, an open grassy space in order to try another, when he learnt that a woodcock had just left this second shola and flown across the open land to the one that 
CREATURES OF THE WILDERNESS 9I

had already been beaten. No one willingly lets a woodcock off in India any more than at home, so back they went through the long grass, almost doubling on their own tracks, and there lay a young sambur calf, wideawake, but crouching close to the earth. The hind had doubtless hidden it there and told it in her own fashion to lie still, whatever happened.

The barasingh, or swamp-deer, is a smaller animal, but its antlers carry many more points, and the brow-tines (which may be compared to the lowest branch of a tree) are very large and conspicuous. Its colour is red along the back and sides and white beneath. It does not, like the sambur, keep to the densest portions of the jungle, but is more often to be found in the high grass in open spaces between two woods and nowhere very far from water, which it needs regularly and at short intervals. For this reason, it is one of the worst sufferers by the native practice referred to above. These men are not first-class shots, and their arms and ammunition are primitive. Europeans, with their modern rifles and knowledge of how to use them, are less objectionable, yet even they might occasionally set the natives a better example than they do. At the same time, the worst enemy of the sambur, at any rate, is not man, black or white, but the dhole, or wild dog, with which most people must be familiar 


\section{THE WILDERNESS AND JUNGLE}

in Kipling's stories, a handsome villain that runs down its prey in packs. From the moment these deadly hunters get on his trail, the stag is doomed and knows it, and in such terror do these deer go of wild dogs that they at once desert a district at the first sign of them. Fortunately, the wild dog is not afraid of man, so that there is not as a rule much difficulty in shooting it, an opportunity of doing which should never be missed, as these animals are among the worst poachers in India. Although, as will presently be shown, the wild dogs of Africa utter a note not unlike that of a foxhound, the ordinary cry of these creatures is more like a howl, barking being an accomplishment acquired in the tame state, though there is no record of when or how it was learnt. These dholes occasionally go mad, like elephants in must, and in that condition they sometimes run amok in the villages, biting men and goats and even, in lonely districts, attacking and killing coolies. They are not carrioneaters, like the jackal, but kill their own food.

To return, after this digression, to the barasingh, it is also known as the Kashmir stag and is regularly shot by sportsmen in October, when its horns are in good condition and the herds are migrating eastwards through the passes and nullahs of the Himalaya. The hinds and fawns, realising perhaps 
that they have nothing to fear, feed close to the villages of the hillmen, but the old stags show great caution and remain on higher ground, where they are among the most difficult of all animals to stalk.

Of Indian antelopes, the handsomest and best known is the blackbuck. By the way, only the old bucks are actually black. Young males and does of all ages are yellow, but as the buck alone is shot for the sake of its black, corkscrew-shaped horns, which measure about twenty inches in a good head, the distinction of colour is not widely appreciated. Though this antelope is a dweller in the plains, occurring almost all over India, from the foot of the Himalaya to the sea coast, it is also found in forest country in the Central Provinces, and it is here, in fact, that the finest trophies are bagged, those from the Madras Presidency being much poorer. The blackbuck is regarded as a very difficult animal to stalk, which is remarkable, considering how it makes itself at home among the crops and in the midst of the native population. It may be that, in this case, the neighbourhood of man has taught it caution. This is the antelope which the rajahs and nabobs used to hunt with tame "cheetahs," or hunting-leopards, and some of them used lynxes for the same sport, but these are no longer employed, and even the hunting-leopard 
94 THE WILDERNESS AND JUNGLE

has gone out of fashion in most parts of India. The cheetah was blindfolded and taken in a cart until within sight of a herd of buck. Then its eyes were uncovered and it was launched on the herd, from which it at once singled out a victim, hurling itself in its direction at so tremendous a pace as often to overtake it at the first onslaught. If it failed, the performance was over, for the cheetah is not one of the persistent try-try-try-again order of animals, but sulks if baulked of its prey and does not dream of making another effort to catch it. It must be admitted that it shows wisdom in this, for, with such a start, the fleet-footed blackbuck would never allow itself to be caught. The hunting-leopard is nowhere very plentiful nowadays, though one well-known sportsman mentions having encountered no fewer than five of these animals in a district in which he was after bison.

\section{LION, TIGER, AND LEOPARD}

Coming now to the carnivorous animals of India, passing mention must be made of the Indian lion. Not everyone seems to realise, indeed, that there are lions anywhere out of Africa. The American puma, it is true, is known by that name in its own country, but it is no more a true lion than its neighbour, the 
jaguar, is a tiger, though known as such. But there are real lions in India, or at any rate in the forest of Gir, in Kathiawar. They are small but very fierce, and have yellow manes. The Nawab of Joonagur strictly preserves these interesting animals, though occasionally allowing distinguished visitors to shoot them. Thus, Ranjitsinhji, now Jam of Nawanagar, was lucky enough to bag one in 1904. Another hunt was planned for the Governor of Bombay a few years ago, and on this occasion one of the party, Major Carnegy, was killed. It is usual to speak of Kathiawar as the last Indian stronghold of this lion of Asia, which is much more plentiful in the neighbouring countries of Persia and Mesopotamia, but as a matter of fact there is no evidence to show that it was ever very widely distributed in India proper, where, indeed, the steaming swamps and gloomy jungle are quite unsuited to the needs of an animal that, if we may judge by the haunts of its African relative, loves sunshine and dry soil. It is a curious fact that tigers are all but unknown in the district inhabited by lions, which makes it impossible to say which of the rival monarchs would be the victor in a fight under natural conditions, although in menageries the tiger has generally proved the better of the two. The lions of India need not further detain us. They do no damage outside of the preserve in 


\section{THE WILDERNESS AND JUNGLE}

which they are left in peace, and they are interesting chiefly as the probable descendants of the lions of Bible story in the lives of Samson and Daniel.

The great cat of India is the tiger, commonly acclaimed Lord of the Jungle. His lordship is not, however, undisputed. I remember reading a story in the Rangoon Gazette of a tame elephant pluckily rescuing its mahout from a tiger. Considering how mahouts often treat their beasts, it was an act of touching devotion. The man had washed the elephant as usual and was driving it to its feeding-ground, the animal walking a little in advance, when, all of a sudden, a tiger charged out of the jungle and knocked him over. The tiger then began to bite, and the man screamed for help. Back came the elephant in no end of a hurry, kicking the tiger into the air with such force that, on reaching the ground again, it fled for dear life, coughing up blood as it ran. Yet, in the great open-air menagerie which we call the jungle, even the elephant is not always master, but goes in deadly fear of the rhinoceros, which, as Dr. Longstaff reminds me, fights differently from its African cousin. The African charges head down and tosses a man or a horse on its horn without difficulty. The Indian rhinoceros, on the contrary, charges head up and inflicts such fearful bites with the sharp teeth of the 


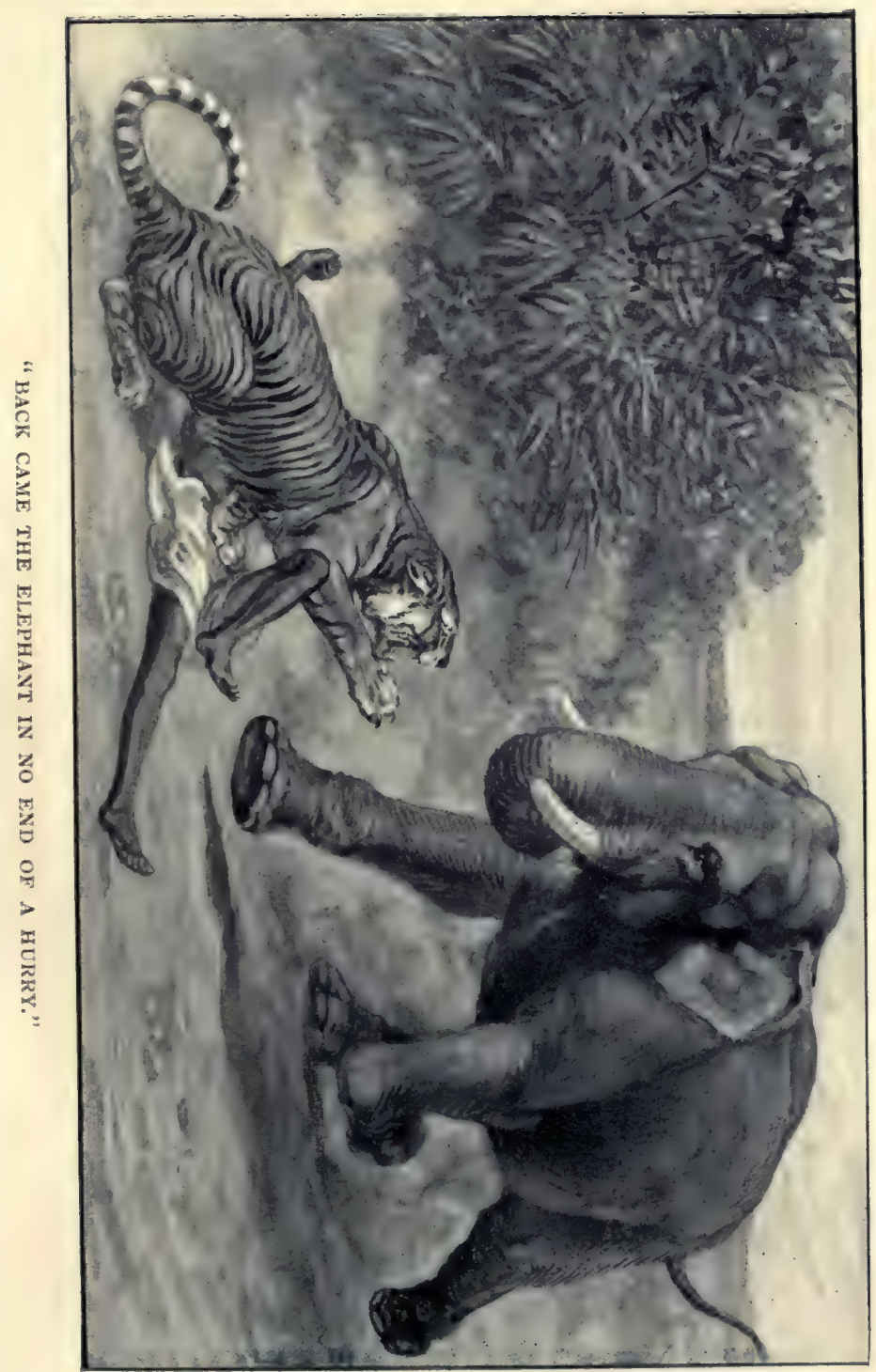



lower jaw as to lame even an elephant in a few moments.

The tiger may be less courageous than the lion. Several anecdotes in illustration of cowardice in both animals will be told in these pages, and, on the whole, the reputation for greater bravery remains with the lion. The tiger may even, in some districts, be less dreaded by the natives than its tree-climbing cousin, the leopard. Yet it remains, all the same, the most terrible creature in Asia. The natives of India hold it, as a rule, in such reverence that they rarely allow themselves to mention its name, even in a whisper. The jackal, in its master's presence, utters a terror-stricken note utterly different from its usual howl. Even Europeans, armed with the latest rifle and ammunition, treat "Stripes" with respect, and those who know him best take fewest liberties when he is prowling around. He is the yellow peril of the jungle, and when he comes gliding sinuously through the undergrowth there is great commotion among the lesser brethren. Squirrels scritch and monkeys chatter with terror, peacocks and jungle-fowl scream, small deer fly panic-stricken out of harm's way. I have seen it suggested that the dislike which many otherwise courageous people have for cats is to be regarded as a survival of the dread in which their monkey ancestors held tigers! 


\section{THE WILDERNESS AND JUNGLE}

This curious fear which many people have of comparatively harmless animals, though quite indifferent to others larger and more dangerous, seems to call for explanation. Earl Roberts, hero of a hundred fights, is often described as being afraid of a cat; and I recollect a case of a lady lion-tamer, who played with bears and lions as if they had been so many kittens, confessing that she ran in terror from a blackbeetle! This only shows how difficult it is to call anyone either brave or cowardly without closer inquiry. Fancy anyone who happened to see the hero of Kandahar shrink from a cat calling him a coward! (As a matter of fact-I have his own authority for the correction-Lord Roberts is not afraid of cats, but merely has an intense dislike of them.) Fancy, even, making the same mistake about a lady who toyed with lions, merely because you happened to see her in full flight before a cockroach !

It is not often that one comes across a story in which the tiger is written of with sympathy, as a fellow-creature and not as vermin, but I am able to include one such view, for which I have to thank Mr. Edwin Arnold.

"Sometimes," writes Mr. Arnold, "I fancy the wild animals know more about human nature than we know of theirs. All the wild 
creatures' instincts and perceptions are in their native freshness, whereas ours are dulled by centuries of artificial surroundings. At any rate, I am convinced that they possess an acute power of recognising sympathy, on the few occasions when man shows any for them, and that they entertain a profound, childlike belief in his power to give and to take, to help, or to destroy, as he pleases. We must, in fact, seem to the beasts of the field something like those implacable spirits, always dreadful, always to be propitiated when possible, with which our own far-off ancestors peopled their woods and hills. Whenever the man-spirit deigns to come down from his pedestal, forgetting his superiority for a little while, and approaching the humbler creation with that mesmeric and infectious goodwill that the animals are so quick to recognise, he finds himself arriving at an understanding of animals' ways and thoughts that he would before have deemed impossible. There is no need for him to be a sentimentalist. Hiawatha, who knew the heart of every wild thing, alternately caressed and used his bow. I have gone many a time into the jungle with my gun and, on coming up with my intended victims, have forgotten my errand, sitting openly among them, delighting in their gambols and piecing together such fragments of their conversation as seemed intelligible. It is true that I returned home empty-handed, but I was well content that it should be so.

"In the man with an inborn gift of sym- 


\section{IOO THE WILDERNESS AND JUNGLE}

pathy, the animals do not resent bloodthirstiness, for that, they know, is part of all Nature. Even though they still dread his power, they no more think of rejecting his friendship than a child would think of refusing the love of a parent who has both the will and the ability to chastise. It is not to be denied that there are occasions on which their belief in your puissance may be embarrassing and their craving for your sympathy inopportune. The following experience will, I think, illustrate a case in point.

"I was walking home through the Indian jungle in the gathering dusk of evening and, when still several miles from any human habitation, I became suddenly aware of a gentle, measured footstep keeping pace with mine about a dozen yards away in the undergrowth. I had no weapon with me more formidable than a white umbrella and so proceeded quietly, wondering as to my companion's identity. It was dark now, and a plaintive mewing suddenly removed all doubt. It was a full-grown tigress. This I knew, of course, from the voice, as the tiger speaks from further down in his throat, with a wholly different effect on the practised ear. To run, even had I been so minded, would have been absurd; to climb a tree, equally futile. There was nothing therefore to be done but to walk quietly on, and I did it. Step by step, following each winding of the little path, absolutely invisible in the shadows, the great beast accompanied me through the forest, every now 
and again giving one of those piteous, longdrawn mews so impressive in the silence. Just at first, I was a little nervous. I remembered having seen the half-eaten remains of brown men and women in that jungle, killed and left by tigers, and it was not by such a process that I wanted to go into eternity. In a few minutes, however, my nerves troubled me no longer. As I walked more slowly and listened to her voice, I became convinced that my invisible friend was in trouble of some sort, and that she was telling me all about it and asking my aid. Indeed, I felt quite certain of this by the time we had gone half a mile, and, as if in response to my silent sympathy, she came a yard or two nearer. It may have been that her cub had got into difficulties-fallen in some waterhole, from which she could not rescue it, or starving in some cleft in the rocks of yonder peak, the inky outline of which, showing dimly through the tree-tops, made a barren space in the starlit sky.

"For all the rest of that long, lonely tramp, I was aching to help her, but that was clearly impossible. I could obviously not wander about a jungle all through the night and at the tail of a disconsolate mother, whose sorrow was possibly vague and uncalled for. Mewing gently every few moments, the tigress accompanied me on my homeward way, up the slopes and down into the hollows, her great velvet paws now and then cracking a twig, and over the rivulets, where she would pause to drink, never giving me a glimpse of her, but ever 


\section{IO2 THE WILDERNESS AND JUNGLE}

asking my help in that strange and melancholy voice. At last the lights of my camp-fires showed in the next dip. I walked on some fifty yards, to where the forest ended in a clearing, and then I stopped and listened. The mewing and footfalls had died away, and I knew, as well as if I could see her, that the tigress was sitting on her haunches in the last clump of bushes, sorrowfully watching me pass out of reach of her appeals. Poor creature! My heart went out to her in her nameless grief. It seemed as if she might be saying- ‘You take; you to whom nothing is impossible, who know my harmlessness and have recognised my grief; you who perhaps have cubs of your own, and yet will not come with me a little way-it is such a very little way-to do that which you could do so easily! You sympathetic? You to call yourself half-friend of the things that run and fly? Bah! I might as well have asked help from the cobra under that stone, or from the monkey coughing in the big fir-tree! See! My mood changes; my tail twitches; come back out of the moonlight into the shadows, and, lord though you be of the red fires there in the hollow, and of the thing that sends death over the hill-sides and nullahs, I will give you a tiger's thanks for your discourtesy!

"Poor tigress! I could do nothing for her, so I went sadly back to camp, but her troubles spoilt my evening, and I lay awake at a late 
CREATURES OF THE WILDERNESS IO3

hour wondering what help she had wanted and despising myself for having failed her."

The tiger is found in most parts of India, but it is absent from the extreme north-west of the peninsula, and is also unknown in Afghanistan and Ceylon. In appearance, it is utterly different from the lion, though both are members of the cat family. It has black stripes, not unlike those of zebras, on its orange coat, and the orange grows paler with age. The tail has no tuft at the end, like that of the lion, and the tiger is also without the lion's mane, though the male wears a handsome ruff on his neck. A fullgrown tiger may measure close on eleven feet from the tip of its snout to the tip of its tail, and, though there has been much talk of tigers measuring twelve feet, none has, so far, been recorded.

The tiger's larder is very varied. Large deer and small antelopes, tame cattle, jungle-fowl, peacocks, and even crocodiles' eggs all figure in his bill of fare. His natural food is wild game, and with that he was doubtless satisfied in olden time before men and their cattle came on the scene to teach him other tastes. Nowadays, however, tigers are divided by Anglo-Indians under three heads-game-eaters, cattle-eaters, and man-eaters. As a matter of fact, not even 


\section{THE WILDERNESS AND JUNGLE}

the foregoing list by any means exhausts the tiger's choice of food, for it is known to prey on bears, leopards, and even other tigers, as well as on buffalo, young elephants, and tapirs, the last being, perhaps, its favourite food in the Malay jungle.

The education of the cattle-eating and man-eating tiger suggests problems not unlike that of the "rogue" elephant, already noticed, but the process is less wrapped in mystery. Antelopes are hard to catch, and young elephants have big mothers to defend them. What, as Americans would say, was wrong with a tender heifer from a tame flock? Enterprising tigers tried the experiment with the most satisfactory results. It must have been so easy to creep silently up to the herd, or, better still, to lie in ambush beside some rock commanding the road along which the native herdsman drove his charges every evening at sundown. To pick out a victim, spring at its head, grip it by the throat and break its neck, must have been child's play to a tiger. Then, when the rest of the herd stampeded, and the panic-stricken native was probably half way up a tree, the dead beast would be dragged away to the jungle and there gradually devoured, the tiger returning to the kill more than once and scattering the jackals and vultures that ravened in his absence. So hearty a meal, 


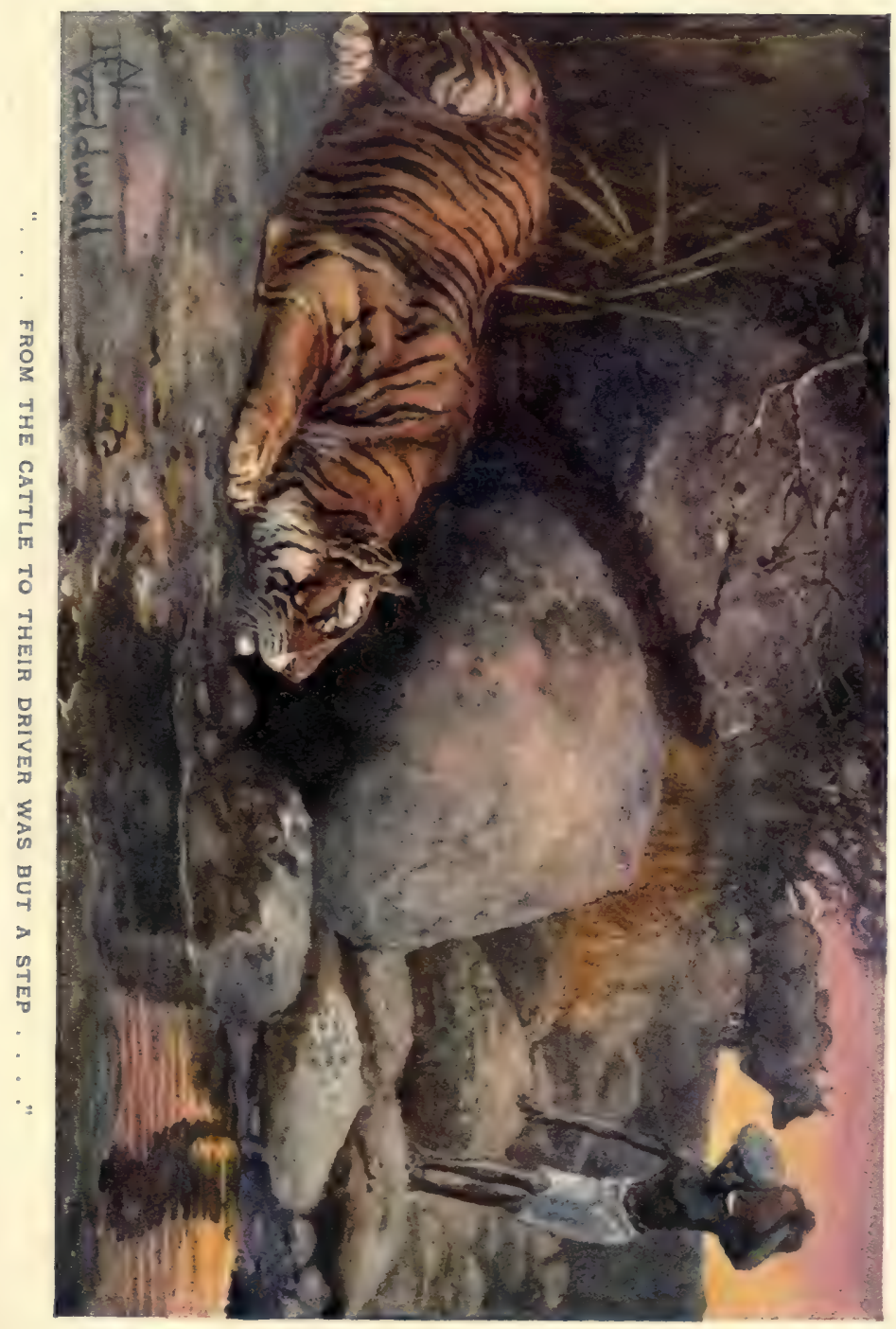


without the fatigue of a chase or the risk of a fight, must have been acclaimed a vast improvement on the old-fashioned way of doing things, and from that day forth the tiger would be a confirmed cattle-eater, never more troubling about other food that could be procured only by means less simple. There is therefore no difficulty whatever in understanding how tigers came to be educated to a taste for beef, and the evolution of the man-eater is as evident, since from the cattle to their driver was but a step, and the first man-eater may have killed his human victim accidentally when springing on one of the herd. Yet, in spite of this easy explanation of the man-eater as he is to-day, all sorts of theories have been suggested to account for him. The least fantastic of these is that man-eaters are aged animals, too slow and too feeble to hunt swifter or stronger game, no longer able to catch blackbuck or to pull down a sambur, and therefore, in their hunger and extremity, forced to prey on the unarmed ryots and woodmen of the jungle. There is no doubt that, with wild animals as with tame (man included), opportunity sometimes makes the thief, and the sight of these inoffensive peasants passing and repassing his lair might, we may easily imagine, put the idea of eating one into a hungry tiger's head. There are, however, one or two 


\section{I06 THE WILDERNESS AND JUNGLE}

undeniable facts which do not, as we shall see, bear out this theory of the man-eating habit. The first of these is that the majority of maneaters are females the recognised offender is, in nine cases out of every ten, a tigress. Another fact, even more hostile to this view, is that man-eaters, when at length they meet the doom they so richly deserve, are by no means always old or infirm animals, but may, on the contrary, be in the prime of life and in splendid condition. Abundance of human food might, to some extent, account for their condition, but even such fare could hardly make an old tiger young again, and the man-eater does not, there is good reason to suppose, eat a great many men in the course of each year. A third objection to the old-age theory is the fact of man-eaters being practically unknown in the Nilgiris and in some other parts of India. Yet we must surely assume that tigers grow old in these districts as well as in those infested by man-eaters, even though they do without human food to the end of their lives. It might possibly be shown that the natives of the Nilgiris are more courageous than those elsewhere, or that they do not go about their work unarmed. I have no further information on the subject, but such an explanation would be of great interest. In its absence, we must certainly find the foregoing theory unsatisfactory. 


\section{CREATURES OF THE WILDERNESS 107}

Not every tiger, or lion, that eats a man is a man-eater by habit. The true man-eater stalks and kills its victims without provocation. If a wounded tiger should charge and kill a man and then devour him, the animal was not necessarily a man-eater before, though such an experience might make one of it henceforth. It is somewhat remarkable that the natives of Africa also regard man-eating lions as old and worn out, and Livingstone quotes them as saying of an old lion, "His teeth are worn; he will soon kill men." As a matter of fact, lions take to man-eating less often than tigers, and leopards more rarely still. The man-eating lions, with which, as told in that extraordinary book of his, The Man-eaters of Tsavo, Colonel Patterson had so much trouble while engaged on railway construction in Africa, took dreadful toll of his coolies, but the leopards destroyed only his sheep and goats, one of them killing a whole flock in a single night. If the leopard, with its facility for climbing trees and lying in wait over the jungle-paths, should take regularly to man-eating, it would indeed be a terrible scourge. It may be that this power of climbing saves man from its appetite, for it is able to catch abundance of monkeys, which, though much appreciated, usually escape the jaws of the tiger. Now and then, it is true, tigers do stalk monkeys, and in some parts of 


\section{I08 THE WILDERNESS AND JUNGLE}

India the natives make use of this taste to get a tiger within shot. In order to do this, the native climbs into the higher branches of a tree close to the tiger's lair and begins to chatter and to break off twigs just as monkeys do. This business is kept up until a stir in the bushes beneath betrays the tiger's presence and interest in the proceedings, and then the native suddenly drops a bundle on the ground and screams. The tiger, thinking that, as sometimes happens, a baby monkey has fallen out of its mother's arms, rushes out into the open, and a rifle, posted in an adjoining tree, covers it before it has time to realise its mistake.

Tigers stalk their prey with extraordinary cunning, but now and again, like all animals, they make a mistake which may, if turned to account, cost them dear. An instance of such an error was reported some time ago in The Field. A sportsman was sitting one moonlight night in his machan, which is a platform erected in a tree, from which sportsmen shoot tigers and other game at night, and he was able to watch, himself unseen, the novel and interesting sight of a tiger stalking a sambur hind. He could not get a shot for a long time, for the simple but sufficient reason that the tiger kept in deep shadow. Then, quite unexpectedly, it made the last mistake of its life, for it came out into the bright moonlight. 
Off went the sambur, and crack went the rifle, so that the tiger lost its meal and its life at the same moment. It is always desirable to take note of these mistakes made by the jungle-folk. They should increase our admiration for them instead of lessening it. Some people pretend to believe that the lower animals never make mistakes. They are so used to saying that "to err is human" that they come to regard man as the only creature capable of miscalculation. Yet animals, both wild and tame, are by no means infallible. Professor Lloyd Morgan, who has made a lifelong study of the mind of animals, calls my attention to the interesting case of some pheasant chicks crossing an open road near a wall. Suddenly, they stood as if struck motionless. At the same moment, a sparrow-hawk dashed over the top of the wall and easily secured one of the brood. Someone asked the Professor why the little creatures did apparently just the wrong thing in the circumstances. His answer was that the chicks had learnt to keep quite still on hearing a warning note from their mother and that, under ordinary circumstances, that would be the very best thing to do in presence of an enemy, as to run about would only betray their presence by the disturbance of the grass. In the open road, where, even keeping still, they were very conspicuous, running away into the 


\section{Io THE WILDERNESS AND JUNGLE}

grass was, on the other hand, their only chance of escape, but they could not know this, their instinct not taking the altered circumstances of the case into account. This may be compared with Colonel Williamson's story of the young sambur in long grass, though Professor Lloyd Morgan does not offer the same suggestion of defective scent as an aid to self-preservation. Then, again, we have the well-known case of tame dogs hunting in India, which, though they ought to learn better, never miss a chance of attacking cobras and other dangerous snakes. The manner in which leopards pursue monkeys in trees has been referred to. If the monkeys would take the simple precaution of roosting only in trees with near neighbours, so that, in case of attack, they could jump from one tree to the next, they would seldom be caught by leopards. But they are foolish enough to go to sleep in solitary trees, with the result that escape is impossible, particularly as a couple of panthers sometimes hunt in company, one of them climbing into the tree and scaring the monkeys so that they presently lose their heads and jump to the ground, only to be caught by the ally in waiting at the foot of the tree. Major F. G. Talbot, D.s.o., told me a similar story, in which the fact of a tree standing alone prevented an Indian squirrel from getting away 
from a most aggressive rook, which attacked the little animal vigorously. Realising that escape was out of the question, the squirrel kept up the fight for an hour, when an unlooked-for interruption came in the arrival of two doves, which immediately drove the rook off and sent it in headlong flight. It is not easy to understand why the doves took the squirrel's part, unless, of course, they had a nest in that tree, though even so the squirrel would have been as likely a poacher as the rook. It may, of course, have been dictated by a chivalrous impulse to protect the weaker side, or it may, again, have been just love of a fight for fighting's sake, though that is not a taste we usually associate with doves.

Reference was made above to the machan, and the success of shooting from these platforms, such as it is, is due to another error of instinct. The tiger, though one of the most careful and suspicious of wild beasts, rarely looks up to see if there is danger overhead. The majority of wild beasts have the same peculiarity, and as, in the natural state, they have nothing to apprehend in that quarter, they never seem to learn to be on the look out for it, though the leopard, itself a climber, generally scans the trees for any sign of an enemy. From repeated reference to leopards climbing trees, the impression might be given that tigers 


\section{2 THE WILDERNESS AND JUNGLE}

are in all cases unable to do so, but this is not the case. Some tigers undoubtedly climb trees, but it cannot be regarded as a common habit with them as with the leopard. The climbers may, of course, be particularly active tigers. This is where so many of us are apt to go wrong in our ideas of wild animals. We do not make allowance for differences in individuals. We speak of a tiger being able to do this, or of an elephant as unable to do that, as if the physical and mental powers of every tiger or every elephant in existence were precisely the same. Why no individuality? Surely no one would dream of describing a boy as a two-legged animal able to turn head over heels or sing in tune, for, as we know, there have been millions of boys unable to do either. Why, then, ignore the same difference in fourfooted animals? To do so in the case of dangerous creatures like tigers may have disastrous results. Some tigers, for instance, whether actually able to climb trees or not, seem able, when standing erect on their hind legs against the trunk of a tree, to reach much higher than others of apparently the same stature. When building a machan, it is of the utmost importance to ensure the sportsman's safety by realising the height to which a tiger can reach, for, though twelve or thirteen feet would be more than the height of the average 
tiger in that position, the machan should be fully twenty feet from the ground, so that its occupant may take no chances.

Passing mention has been made of the curious note of the jackal in presence of a tiger. It is very peculiar and is quite different from the ordinary serenade of jackals in their own company. Europeans look upon it as a note of kindly warning to the forest animals that the monarch is approaching and that they had best clear out of his way while there is yet time for escape. The jungle-men know better. They know that, whatever may be the jackal's virtues, kindness of heart is not one of them. It is clearly to the advantage of this humble hanger-on that the tiger should not be baulked of his prey, for when he is gorged the jackal has some chance of feeding on crumbs from the royal table. Yet we are asked to believe that the unselfish, tender-hearted jackal deliberately does itself out of a meal by warning the small deer that their enemy is near. No ; the "tiger-cry" of the jackal is probably a howl of uneasy terror, which it cannot help any more than tame dogs can help howling when frightened by anything uncanny. It is, indeed, only in moments of fear or pain that our domestic dogs forget their civilised trick of barking and revert to the dismal howl of their wild ancestors. 


\section{THE WILDERNESS AND JUNGLE}

As a matter of fact, experienced sportsmen are able to tell at once whether their spaniels or pointers are barking at dangerous game, such as tiger or leopard, or at monkeys, deer, or jungle fowl. The note in the case of the former is much sharper and more suggestive of mingled excitement and fierceness. It is not therefore surprising that a similar difference of note should be remarked in a wild cousin of the dog like the jackal.

Time was when the jackal was regarded as the provider of the meal for lions, tigers, and other royal patrons, but we know now that he follows instead of showing the way. With reference to what was said above of the manner in which the jackal is supposed to warn the weak creatures of the wilderness, I am aware that cattle-birds may, from one point of view, be regarded as betraying to the hunter the whereabouts of hidden buffalo; but it must be remembered that they likewise warn the buffalo of the presence of the hunter, and that, after all, is their natural purpose.

The tiger is a fine swimmer and always keeps in the neighbourhood of water. The leopard, on the other hand, is not a very thirsty animal and, being but a poor swimmer, rarely, even when pursued, takes to deep or swift water. In Northern India tigers are mostly shot from the back of an elephant, as 
sport from a howdah affords most of the excitement, with very little of the risk, the worst that may happen (and it is quite bad enough) being that the elephant should take fright and stampede into the jungle, brushing its occupant off its back and tumbling him on the ground, with an infuriated tiger somewhere handy. This, however, is of fortunately rare occurrence. It is remarkable how easily two or three men on an elephant seem time after time to escape the notice of tigers and other wild animals on the ground. This, no doubt, is partly due to the tiger's failure to look for danger from overhead, an omission already alluded to, but it is also, we may assume, the result of his mistaking a single elephant for a wild one, and therefore taking very little notice of it. When a number of elephants are used in beating up tigers, the latter are fully aware of the danger that threatens them, but a single one does not seem to excite their suspicion until the first shot is fired.

Though a terrible fellow to come across at close quarters when wounded, the tiger is, under ordinary circumstances, an arrant coward. Give him a chance to slink away and he will do so. (Do not give a lion the same chance, for, though he does not always do so, he is quite likely to slink in your direction, which is a very different matter.) Unless 


\section{I16 THE WILDERNESS AND JUNGLE}

provoked, the tiger takes good care to keep out of the way of Europeans ; and, hard as it is to make the "Griffin" (i.e. the new-comer) believe it, he is probably, unless a cool shot, far safer in the forest without a rifle than with one, and all the protection he needs is a pair of leggings and a good stick for the snakes. In point of fact the jungle is in reality a much less terrible place than our stay-at-home friends picture it. Half its dangers are the result of imagination, and most of the other half are the result of lying on the part of those who cannot bear to return home without having enjoyed, on paper at any rate, their share of wild adventure. The method of shooting tigers from a machan has been mentioned. This entails tying up a goat or some other animal for bait, and also sitting up all night. The sounds and sights of the jungle on a warm Indian night are not without their attraction, but the results are not as a rule very satisfactory, as some little mistake may warn the tiger to stay away, or, when it comes in sight, the darkness may be so intense that it is impossible to take aim. There are even intrepid sportsmen who shoot tigers on foot, which is not a recreation for anyone with "nerves"; and in the winding waterways of the Sunderbunds it is occasionally possible to get a shot at one from a boat. Now and again, 
indeed, these terrible animals have been killed with simpler weapons. Sir James Outram slew one with a spear, and Colonel Duff was equally successful with a dagger.

We are even assured that it is possible for anyone who may suddenly come unarmed on a tiger to quell the brute by staring at it. This is one of the thrilling experiences I prefer reading about. It suggests memories of the redoubtable Major Corker in "Aliph Cheem's" amusing Lays of Ind, in which, as you may remember, the Major says :

"I laid my Purdey down, to my shikaree's great surprise, And crossed my arms and calmly stared the tiger in the eyes ..."

a treatment which the valiant warrior repeated till the tiger lay dead in its den. Mesmeric powers of this order are sometimes claimed by vain and foolish natives, invariably with unpleasant results. Thus, a Sepoy of the $33 \mathrm{rd}$ Sikhs made the experiment at the Calcutta Zoo not long ago, and lost most of his face for his trouble; and a Hindu of Bangalore was badly mauled on another occasion, when several villagers, interested spectators of the great man's demonstration of his occult powers, suffered even more serious injuries than he did himself. In these days of long-range rifles, hunter and hunted rarely come face to face at 


\section{THE WILDERNESS AND JUNGLE}

sufficiently close quarters to allow of these hypnotic attempts, yet one or two have been brought to my notice. A case of the sort, reported in The Field, actually occurred as recently as 1910. A sportsman was out with his shikari (native gillie) in the Himalaya, and the man was walking about ten paces ahead, carrying his master's 450 rifle. They were proceeding slowly through a thick forest of cedars when, of a sudden and without warning, the man stopped dead. The Englishman stopped also, and observed that the man, without turning his head, was beckoning him and holding out the rifle. On going up to the shikari, he saw a great panther sprawling on a rock some thirty feet below them. The panther was gazing intently at the native, who never once took his eyes off it, and the animal certainly seemed either unable or unwilling to move. The suspense seemed to last for several minutes, but was in reality a matter only of seconds, though time enough to enable the sportsman to slip in his cartridges, take careful aim and shoot the panther dead, with a bullet between the shoulders. He did not feel it a particularly creditable achievement to shoot an animal apparently mesmerised, but the panther in question had achieved an unenviable notoriety in the district as a cattle-thief, so it was better dead than alive. What he puzzled over 
afterwards was as to what would have happened if he had not had his rifle handy. Would the panther have slunk off, or would it have looked away, so as to break the spell, and then charged the native? The question is such an interesting one that it was almost a pity it had to remain unanswered. But in all probability the native preferred his employer's solution to any other. One or two lion stories, bearing on this same influence of the human eye, will be told in their proper place. How far such power may be effectual in the wilderness remains an open question, but it may, in passing, be remarked that its failure in menageries is no criterion whatever, since captive lions and tigers have, for obvious reasons, become so familiar with human beings as to have lost that fear of them which may, for aught we know, inspire those in the wild state that are rarely brought face to face with man.

For an unarmed native to kill a tiger in its cave must be an unusual occurrence, but a case was communicated to The Field in which this actually happened, and it was certainly turning the tables with a vengeance. The natives in some parts of India have a great liking for roast porcupine, and, speaking from experience, I can say that they might do worse. When, therefore, they come to one of the small caves in which porcupines commonly lie up during 


\section{I20 THE WILDERNESS AND JUNGLE}

the day they sometimes light a fire at the mouth of it and watch for a drowsy, half-suffocated porcupine to emerge. A native, with this object in view, once set fire to a great heap of brushwood piled in front of a likely looking cave and took up a position from which he could see what happened. Nothing did happen, and, although the natives of India are patient beyond most men, he gave up his vigil at last, and tramped home disappointed with his bad luck. Next day he passed the cave again, out of curiosity, and was amazed to find, lying just inside the entrance, a young tigress suffocated to death. She dared not make a dash for liberty through the smoke, not only because she was probably afraid of the flames, but for the still sounder reason that she knew that her charge must inevitably have carried her over the edge of the rock to a drop of at least fifty feet into a deep waterhole below.

Now and again tiger-cubs are captured after the death of the mother, and I am indebted to a correspondent for an account of two such occasions, on the second of which, as will be seen, the smoking-out method was also applied, though far more scientifically than in the case recorded above. It played no part, however, in the capture of a brace of cubs during a Christmas shoot in 1905, in H.H. the Maharajah's reserve at Sacribail, 
Mysore. My informant was walking along a jungle-path a couple of hours before daylight hoping to get a shot at sambur stags at dawn, when he and his two shikaris were suddenly arrested by the sound of animals moving in the dry bamboo leaves close by. They crouched down on the chance of getting a shot at the animals, whatever they might be, as they crossed a small open space immediately ahead. Suddenly they saw a tiger circling the party, with the object of getting behind and above for a spring. The Englishman immediately put up his 500 express and fired at the tiger's right shoulder, whereupon it vanished down a deep nullah. Just before daylight, a cub showed up in the tiger's tracks and then retired again. Then the day came, and they set about following the tiger up. They were not long in coming on the animal, which proved to be a tigress. She had gone only a hundred yards and had then died, sitting up for all the world like one of the lions in Trafalgar Square and holding in her mouth a huge bunch of grass that she had seized in her rage. She must, indeed, have been in the act of springing when fired at, for the bullet, instead of penetrating behind the shoulder, had entered the centre of the chest, raked the heart and come out behind the ribs.

It now remained to secure the cubs, and 


\section{THE WILDERNESS AND JUNGLE}

that afternoon they got some nets and drove the valley into them, capturing a fine pair of cubs the size of mastiffs. As soon as the nets were over them the villagers placed the ends of long bamboo poles on the cubs and sat on the ends of the poles so as to hinder them from struggling, while men went close up and secured them with ropes. The cubs were eventually presented to His Highness and found their way to the fine Zoological Gardens at Mysore.

Within the year, two more cubs were captured by the clever tactics of Dafadar Taman Sing and four other members of Gordon's Horse during a shoot in the Kinwet Reserve, Central Provinces, under the following circumstances. An officer in that regiment had shot and mortally wounded a tigress that was sunning herself, half asleep, in the mouth of a cave. She managed, however, to dash out for a hundred yards, along the edge of a steep declivity, before a second shot rolled her over, dead, on the rocks forty feet below. At the same moment a well-grown cub was seen to leave the cave and to go back into it, and arrangements were accordingly made to build up the exit, and, if possible, to get the cub next day. Further investigation revealed no fewer than eight caverns, each of which possibly communicated with the rest, and there 
CREATURES OF THE WILDERNESS 123

were numerous tracks of tiger, bear, and hyena.

Taking all necessary precaution against a sudden charge, the party built up the eight entrances securely with rocks and timber. Next morning the entrance in which the cub had been seen overnight was carefully opened, and it was found necessary, after making a chevaux de frise of hog-spears, to enlarge this entrance by excavating the floor to a depth of more than a foot. It was then found, on probing the interior of the cavern, that there was an outer chamber, about fifteen feet in diameter, from which an entrance two feet square led to an inner chamber of considerable depth so far as could be judged. In the course of these operations, a deep growl from the interior announced that a tiger was at home, but whether it was the full-grown male or merely a cub could not at once be determined. Two of the regimental shikaris, Naik Athman Sing and Sowar Jeimal Sing, now entered the outer chamber armed with hogspears and made certain that there were no other exits. A number of bundles of dry grass were now cut and pushed, with the aid of a twenty-foot bamboo, into the inner chamber, and a torch was next lit and thrust in on the bamboo, while the mouth of the cavern was completely covered with blankets held in place 


\section{I24 THE WILDERNESS AND JUNGLE}

by the cavalry sowars. Smoke soon began to issue through the crevices and the cave was soon full of it. A tiger's nose now rubbed against the blanket held by Athman Sing, and, thinking it must be a full-grown one, he quietly lowered a corner of the blanket to enable the officer, who was standing ready, to shoot it dead. On seeing, however, that it was only a cub, the shikaris fell on it with their blankets and, after a short struggle, succeeded in securing it and in tying up its feet and jaws. A second cub now came to the mouth of the cave, but turned again and fell, stupefied, by the smoke. It was pulled out by the tail, tied up, and revived by fanning and sprinkling its face with water. This was the fourth occasion, by the way, on which the shikaris of Gordon's Horse had robbed a tiger's den.

In a subsequent chapter will be found one or two stories in which tigers took terrible vengeance on those who molested them. Few wild animals, indeed, are more dangerous when wounded, in good covert, such as long grass, and when a man has shot thirty-six of them on foot, and in no other way, he needs to have had occasional luck even if he was one of the best rifle shots in India in his day. Colonel Williamson had one or two lucky chances of this kind, and one 
he tells me of will serve to show how fortune sometimes smiles on the sportsman. He was out one evening after deer, and he thought that he saw a deer of some sort standing in a patch of thick covert. There was the tawny hide and the animal seemed about the right height, when, suddenly, he saw that it was striped. It was only a few yards distant, but he at once fired, aiming as well as he could for the shoulder-blade. Then, backing cautiously from the covert, and never taking his eyes off what was behind it, he slipped in another cartridge and waited. There was neither sound nor movement, and his suspense was not lessened by the fact that he had sent a none too intelligent native for water and, for aught he knew, the man, who was no shikari, might come blundering right on the wounded brute. Fortunately, the native caught sight of him and gathered from his attitude that there was something afoot. The Colonel had noticed, just before he saw the tiger, that there was an open space through the branches and that the covert was of no great extent, so he now made a circle, always with his eyes on the spot where he knew the tiger to be, in order to come up to the spot from the other side, where it was fairly open. What actually had happened, as he realised next moment to his surprise, was that the tiger lay on the 


\section{THE WILDERNESS AND JUNGLE}

ground, stretched out at full length, dead, the shot having taken instant effect.

Another very remarkable piece of luck befell a Malay, who had the probably unique experience of shooting two tigers dead with an old muzzle-loader charged with a bullet and four buckshot. The man saw a tiger in the jungle about twenty yards away, and fired at it. It was a reckless thing to do, but the brute fell. When he crept cautiously up to where it lay, what was his surprise to find not one dead animal but two, a male and female, side by side! This extraordinary adventure was, as might be expected, soon common knowledge in the district, and an official of the Selangor Museum made a careful examination of the dead beasts, finding that in each case a single shot, no larger than a pea, had gone clean through the heart. Such luck is all but incredible, and is like that of little boys who so often catch the best fish in the river with the cheapest of tackle, while strangers to the water are unable to make a basket with the most costly outfit procurable.

Of the Indian leopard something has incidentally been said in the foregoing account of the tiger. When the sportsman arrives in India he is told that there are several kinds of 
leopard in that country, and is cautioned to distinguish between the panther, the leopard, and the black leopard. As a matter of fact, leaving aside the distinct "hunting-leopard," already referred to, and the snow-leopard of the mountains, there is, in the whole of India, only one kind of leopard, though there is a large race and a small race, and ordinary leopards sometimes have a black cub in the same litter as others of lighter colour. The biggest leopard would probably not measure much more than eight feet from snout to tail, and the smaller type would fall a little short of six feet. Its spotted skin is as familiar as the tiger's stripes.

Of the snow-leopard, or ounce, one of the most beautiful of mountain carnivora, we know less than of its cousins in the plains. Its food must consist of the lambs of mountain sheep, though the watchfulness of the argali must be a source of trouble when a hungry ounce is prowling after a meal, and the animal must often have to content itself with marmots and such insignificant prey.

The leopard is less frightened of man than the tiger, and this, with the animal's habit of lying in trees, makes it an object of constant fear to the natives of the jungle. Attention has been drawn to the comparative scarcity of maneating leopards, but these pests are by no 


\section{THE WILDERNESS AND JUNGLE}

means unknown, and, in fact, two were shot in the Central Provinces during the year I9II. As an instance of the contempt in which these brutes hold the native, it was also in I9I I that one broke, according to the Pioneer Mail, into the Small Arms Factory at Kirkee, one morning at an hour when all hands were at work and managed to maul a native before some of the Europeans could shoot it, which they subsequently did. The favourite meal of the leopard is a dog, and it is bold enough, when hungry, to snatch one from under its owner's nose. Tigers are much less given to stealing dogs in India than leopards, but in Burma they often do so. The largest leopards kill deer and antelopes, but the smaller prey on hares, monkeys, and jungle-fowl. So bitter is the feud between leopards and dogs, that not only is the leopard commonly attacked by wild dogs, but even a small pack of tame ones will, without difficulty, bring one to bay in a tree. It is more active during the day than the tiger, and is found in the mountains up to an elevation of eight thousand feet, which would be about the lowest limit of the snow-leopard, or ounce, a magnificent animal with a long, furry skin, which is thought to live as high as twenty thousand feet. Though both are large cats, the leopard and tiger differ in their manner of feeding, for whereas the tiger begins with the 
head and fore-quarters of its kill, the leopard invariably eats the hind-quarters first, nor does it return to the same meal as regularly as the tiger. It is probably the most destructive animal in India, and does much more damage to farm stock than its more powerful cousin. One that was eventually shot, but that, never having been fired at previously, displayed amazing boldness in its raids, was known to have accounted in a single year for no fewer than three ponies and fourteen calves and buffaloes, to say nothing of such smaller items in the bill as dogs, fowls, and goats! Like the tiger, the leopard is occasionally known to eat its own kind, and one has actually been seen to attack another leopard that had been wounded, first killing it and then eating part of its carcase.

Panthers and hyenas are known to share the same caves, using one entrance, but different compartments within. The explanation of this curious partnership is probably that the panther takes refuge in the first instance in the hyena's den to bring up her family. This association of hyenas with panthers lends point to a very interesting experience that an acquaintance of mine had some years ago at a jungle hamlet in the Bhegum of Bhopal's Reserves. It was a little before midnight in June, and some hyenas were observed feeding 


\section{THE WILDERNESS AND JUNGLE}

on a panther's kill. Some sloth bears shambled up to drink at a pool close by, but the hyenas frightened them off by imitating the growling of panthers. By way of retribution, the panther itself actually turned up a little later, and the hyenas in their turn decamped.

When desperate with hunger, leopards are among the most daring of wild animals. A correspondent tells me of one that one night entered the hamlet of Jauli and was pursued by the natives and their dogs, running across an open space in the moonlight for about five hundred yards and then being brought to bay in a clump of bushes surrounding a solitary tree, where the animal was kept until two sportsmen arrived and shot it dead.

Yet the most extraordinary instance of daring on the part of one of these creatures is one, for the story of which I am indebted to the same gentleman. It was in the summer of 1907 that he and a friend arrived after a long march at the Behreye Bungalow, in the midst of a jungle noted for man-eaters, and a native travelling circus, one of the entertainments most appreciated in India, had also halted at the bungalow. The proprietor made his obeisance to the sahibs and informed them that the chief rooms would at once be placed at their disposal. The most popular "turn" of the show was a combined performance of dogs and panthers. Two tame 
panthers, whose claws had been cut and molars removed as a precautionary measure, were caged on a cart and the dogs roamed about the circus encampment. The panthers, realising perhaps that there must be some of their friends in the neighbouring jungle, never ceased uttering the peculiar coughing grunt of their kind, and a fine wild panther actually did enter the camp and, standing (as his tracks subsequently proved) on his hind legs, carry on a lengthy conversation with his imprisoned relatives. Then, no doubt, he thought that refreshments should be forthcoming to celebrate the gathering of the clan. He had not far to go. At this moment, we may surmise, Fido (described by its proud owner as "the most marvellous intelligent performing dog in the world ") came on the scene and, mistaking the hungry visitor for one of the toothless brigade, dashed forward with a view to practising the "side-splitting clown act." Alas, for mental culture! The sahibs, dining at their table less than thirty yards away, heard a yelp, but it was too late, for the harlequin intruder had gone out into the darkness with the "funniest clown dog ever seen" in his jaws. It is interesting to remember that Behreye Bungalow is in the jungle called Seoni Chappàra, the Seoni of Kipling's Jungle Book.

Leopards are plentiful in Ceylon, where, as 


\section{THE WILDERNESS AND JUNGLE}

there are no tigers, they are the most dangerous beasts of prey in the island. Dr. Longstaff tells me of a curious mistake made by a male panther, which, though the female had just been shot in its presence from a machan, came round her five minutes later, instead of making off into the jungle, and was shot as well.

People have made pets of both tigers and leopards, in both cases as cubs, and Colonel Williamson, who had experience of both, is inclined to regard the tiger as of the two the more reliable. He once made a great pet of a young tiger in India, but, as it made a good deal of noise, besides alarming some of the neighbours, he was eventually obliged to find another home for the animal and gave it to the people's park in Madras. Then, being transferred to another district, he saw no more of it for quite three years, when he again had an opportunity of seeing how it was getting on. At the first sound of his voice, the tiger, now considerably larger than when they had parted, came to the front of its cage and rubbed itself backwards and forwards against the bars, as cats, large as well as small, always do when pleased.

He also, at another time, had a favourite leopard cub which at first had to be fed with a rag dipped in milk and water, which it swallowed in course of worrying the rag. It 
was a playful little creature and made great friends with another pet of that period, a little muntjac, or barking deer. The muntjac is armed with two very long canine teeth and is able, when full-grown, to use them to good purpose. Indeed, on one occasion Colonel Williamson thought he had lost a valuable spaniel (the breed that, more than all others, keeps its scent in the hottest parts of India) that had been ripped by one of these deer. First aid was, however, promptly available and the spaniel was on the warpath again next day. It bit through the rope and tracked its master up for miles, and he heard its voice among the others hunting a shola. The pet muntjac and the leopard were constant playmates, and when tiffin was served the muntjac would alight with one bound on the table and inspect the food, often followed by the leopard.

The latter, though it had never tasted anything stronger than milk and cooked meat, fed by hand, soon displayed its natural instincts, and when, of an evening, its owner sat reading, it would stalk him, creeping silently across the floor of the bungalow and suddenly springing on the back of his chair and pretending to bite the top of his head. Pretence was harmless and, as the Colonel says, his skull was hard enough to withstand such pleasantries, but the playfulness of the 


\section{THE WILDERNESS AND JUNGLE}

leopard nearly led to trouble. It was on the best of terms with all the household and quite friendly with the neighbours, so that it was allowed to roam at large without fear of accident. One day, however, in famine time, a party of natives went past the door talking over the high price of rice in the market, and a little way behind the rest trudged a woman with a baby in her arms. This was too good an opportunity to lose, and the playful leopard proceeded to stalk the woman, getting close up before she turned her head and caught sight of it in the act of springing. With a yell, the devoted mother flung her baby on the ground and took to her heels, and the leopard alighted beside the child and proceeded, using no more strength than it had previously exercised unrebuked on its owner's scalp, to bite its nose. The effect was, as may be imagined, somewhat different from that to which the leopard was accustomed, for back came the distraught mother, who had forgotten to carry her child out of danger, calling on all her gods and vowing that the baby would die. Fortunately Colonel Williamson was at home, and he at once set about bathing the infant's face and soothing it into silence, which was more than he could do with the mother, who was now screaming herself into hysterics. However, a present of a couple of rupees 
proved helpful, and another rupee or two changed hands when she returned, more than once, to tell the sahib that he was right and that the child was none the worse for its fright. The reason why the infant got off without any risk of blood poisoning was that the teeth and claws of the tame leopard, which had never tasted carrion, were perfectly clean. In the wild state, on the other hand, the claws more particularly, which are grooved, get very dirty, and it is to clean the remains of food out of the grooves that tigers, leopards, and all retractile-clawed cats are so fond of digging their claws into the bark of trees and tearing them through the bark, just like the cat does with the chair legs.

\section{BEARS}

India has three bears, which differ considerably in their habits and appearance. The most familiar of the trio is the black bear, also called sloth bear, at any rate by those people who have never been chased by one. After such an experience they call it the black bear, for once they have seen the animal come rolling and tumbling downhill at terrific pace, and then bite off most of a native's head almost before he has realised his danger, they realise that the other name is not appropriate. The animal has a black and shaggy coat, with 


\section{I36 THE WILDERNESS AND JUNGLE}

short fur, a yellow-white horseshoe patch on its chest, thick lips, long tongue, and terrible white claws. Like the majority of bears in both hemispheres, it is a peaceful creature when let alone, its favourite food consisting of "white ants," honey, and wild mulberries. The teeth and jaws can do terrific execution, though the formidable claws are also used in battle. As it is a cleaner feeder than the tiger or leopard, neither teeth nor claws inflict the same festering wounds as theirs do. It spends a considerable portion of its life in caves and rocks, and sportsmen sometimes manage to get a shot at one by laying in wait at daybreak near the mouth of one of these dens, and watching for the animal to return from its feeding-grounds. Taken young, the black bear may even be made a pet, and a couple were kept in this way at a country house not far from Abergavenny. The temper of these animals is, however, rather uncertain, and caution is required in handling them.

The true black bear is found in Kashmir and elsewhere in the Himalaya. Like the last species, it has a white collar, but the rest of the fur is black. This bear has been known to measure over six feet, without the short tail, so that it is larger than the sloth bear. It eats carrion or fruit and kills cattle, and the hillmen fear it more than the red bear. 
The brown, or red, bear of Kashmir, though more given than the others to killing cattle, is far less dreaded by the natives. Whereas the sloth bear is active all the year round, the brown one goes into winter quarters a little before Christmas, coming out of hiding towards the end of March. Like most bears, and many other wild animals, it has not very good eyesight or hearing, but its scent is keen. In the summer it retires to the higher jungle, but later in the year it comes down to the cultivated area in search of grain, and is even found in the valleys. Nearly all bears are fond of decaying food, and they often bury the animals they kill so that the meat may acquire a flavour strong enough for their palate.

Though quiet enough if not molested, the red bear can be very savage when wounded, and on one occasion Captain Arbuthnot and his shikari, following up a wounded bear in Kashmir, were both knocked flat by its charge. Fortunately it rushed headlong, and did not turn in its flight.

\section{JACKALS}

Jackals, though they are doubtless cowardly animals under ordinary circumstances, similar in their behaviour to the coyote of the American prairies, are capable of showing bravery in 


\section{${ }_{3} 8$ THE WILDERNESS AND JUNGLE}

defence of their young. A spaniel belonging to Colonel Williamson one day came running back to its master, with a jackal in hot pursuit, and with her were several little cubs snarling at the intruder with a fine show of courage. As a case of extraordinary and inexplicable behaviour on the part of a jackal, the following episode is of interest, even though its causes must be left to the reader's imagination. One of these animals suddenly started careering round a sportsman, coming closer and closer until it passed within reach. He and his shikari were at a loss to account for its conduct, never having seen any incident of the kind before, and the only opinion expressed on the occasion was that the animal might perhaps have been bitten by a snake. Nearer and nearer it came in its circuit until, wishing rather to drive it off than to hurt it, the shikari actually hit it over the head with the back of his knife, when the jackal started circling in the opposite direction and then trotted off as if cured of its foolishness. I distinctly recollect reading somewhere a similar story of an English fox, and the suggested explanation, unless I am mistaken, was that it might have been a tame animal escaped from captivity, but this would not apply in the case of the jackal. 


\section{SNAKES AND CROCODILES}

This short list of animals, which the sportsman is likely to meet in India, while in no way intended to be complete, must be brought to a conclusion with a few words on two orders of reptiles, with both of which he is certain to come in contact sooner or later-snakes and crocodiles. The krait and cobra are deadly reptiles, and their bite is the cause of thousands of human lives being lost every year, for nothing will cure the natives of going barefoot through the jungle. This habit is doubly fatal, since not only does it leave their feet and ankles unprotected against the venomous fangs, but it also means that they are continually, with their silent tread, coming suddenly on some basking snake, which, given no opportunity of escaping, is sure to strike. When, on the contrary, Europeans come crashing through the forest, the cobra, like the tiger, always prefers to quit. The cobra is a familiar snake in books and menageries, with the curious hood, decorated with a pattern like a pair of spectacles, which it spreads when angry. The natural history books of other days used to tell us that the cobra spread its hood in order to scare its enemies. Such a result would be interesting, only, unfortunately, it happens only in books, for no one ever yet saw a dog 


\section{I4O THE WILDERNESS AND JUNGLE}

or mongoose scared by the sight of a cobra's hood. Nor, so far as we can see, is the snake's venom (which is wrongly called "poison") of much use to it. It may, no doubt, cause the death of a buffalo or boar, but it does not take effect at once, and the dying animal has ample time in which to kill the snake before its own hour comes. The mongoose-most of us can remember Rikki-tikkiis a sworn foe of all the snake tribe, and particularly of the cobra. Many remarkable stories are told of the plucky little creature and its deadly combats with cobras. Some say that its skin is proof against the reptile's fangs; others declare that, on being bitten, it rushes off to the jungle and devours a particular herb that it knows to be an efficient antidote. These little efforts of the imagination are not without interest, but Nature is quite wonderful enough without embroidery of this sort. The secret of success with the mongoose is far simpler. It consists in not being bitten at all. Prevention is better than cure, and by snapping at its wriggling enemy, and jumping out of reach before the other can strike back, it gradually wears it out until, at the last, it is able to give one last bite and finish it off. I have seen snake-charmers show wonderful indifference when handling deadly snakes, but some of their courage was after- 
wards discounted when it was discovered that the snakes had been rendered perfectly harmless by the simple process of drawing or filing their fangs. It happens now and again, however, that a snake-charmer, performing with the genuine article, is bitten, and then he just dies like any other mortal. The question of the extent to which even the most dangerous snakes will attack a man without provocation is a matter of opinion, and travellers are by no means agreed on the subject. As was said above, it is the silent, bare-footed natives who run the greatest risk, and the cobra bites (it bites, and does not sting) less from any desire to kill than for fear of having its escape cut off. At the same time, Major Talbot writes that he once saw a hamadryad, a large Indian cobra that feeds only on other snakes, chase a man, who had done nothing to provoke its anger, and follow him for some distance. Why, unless, perhaps, it had its young ones to defend, a snake of such tastes should want to hunt a man is a mystery.

Crocodiles are plentiful in most parts of India, and in some districts they are held sacred by the natives. One kind, known as the gharial, has a long and slender beak, and it is generally described in print as feeding only on fish, and being incapable of eating a human being. This sort of general descrip- 
142 THE WILDERNESS AND JUNGLE

tion of a creature's habits from its appearance was at one time very popular in books, but it may have its drawbacks when taken too literally, for, as a matter of fact, gharials have been actually seen to carry off both men and cattle. Practice in such cases is better than theory, and it is best to give these so-called fish-eaters a wide berth, since there can be very little satisfaction to remember, at the moment of being seized, that, with a beak of that shape, the naughty gharial ought to have been content with fish. In the same way it is usual to insist in print that the heloderm of Arizona and neighbouring states is the only venomous lizard in the wide world. It may be, though, curiously enough, grave doubts have recently been thrown on the danger of its bite. The fact, however, remains that there is a strong feeling among the natives of India that a lizard, known as the goisamp, also gives a deadly bite. As the natives are not always misinformed in matters of natural history, it may at any rate be worth while to give the goisamp the benefit of the doubt!

There seems to be an idea that male crocodiles are much less numerous in the East than females, but this rests on a wrong interpretation of the fact that, whereas the males remain out in deep water, it is the females only that get trapped or shot when coming ashore to 
deposit their eggs in the mud. It thus happens that three or four females are killed to every male, so people come to the hasty conclusion that the females are much more plentiful. The probability is, on the contrary, that, by remaining out of reach, the males survive in greater numbers than their mates. Some of the big tank crocodiles are very vicious, and, though human beings mostly keep out of their way, many a dog goes into their jaws. I remember being told of one case, though, in Ceylon, in which a crocodile grabbed a terrier in its teeth and sailed away with it. Fortunately the dog's owner was on the bank, and he immediately put a bullet in the crocodile's head, with the result that it at once dropped its prey. The terrier swam ashore with all its might, and the crocodile gave chase, but the brute was kept off by repeated shots fired just behind the dog. The terrier was badly bitten, but its wounds soon healed. Curiously enough, it learnt no lesson from its accident, but had to be forcibly prevented from jumping into the same tank again shortly afterwards. It may, of course, have been an uncommonly foolish terrier. I do not know its history. Yet this kind of story always occurs to me whenever I hear some particularly devoted admirer of dogs holding forth about their superiority to ourselves. It is difficult to imagine any man, not an idiot, 


\section{I44 THE WILDERNESS AND JUNGLE}

ever again so much as putting his toe in a tank where he had been served in such fashion, yet with the terrier, at any rate, there was no question of once bit, twice shy. Crocodiles do not, as some writers seem to imagine, object to salt water, for they are at times only too common on the coast of Penang, and have more than once seized bathers in the sea.

Crocodiles and alligators show extraordinary boldness in many Indian tanks and rivers, probably because, being held sacred, they get a very poor idea of human beings. Now, sharks, on the other hand, rarely, if ever, attack a party of swimmers bathing and splashing together. It is the solitary swimmer only who runs serious risk from these monsters. In more than one tropical sea I have bathed in company, with the fins of large sharks cleaving the surface just outside the reef. I do not pretend that I liked it, but none of the others seemed to mind, and it was no good making a fuss. Moreover, the weather was hot, and the water was cool, so there were temptations. Such liberties must not, however, be taken with alligators. Not very long ago, the native crew of a liner anchored in the Hooghly were swimming round the ship, when suddenly an officer on deck noticed a huge mugger paddling silently up to them, its long snout showing just above the surface. Next instant the brute shot 
among the bathers with a terrific commotion, and pandemonium reigned while the lascars squealed and scrambled for the ladder, up which the last of them only just managed to clamber as the alligator snapped its jaws just clear of his feet. Meanwhile the officer was busy emptying the chambers of his revolver all round the brute, which evidently realized that it had been defrauded of its meal, since it lashed the water furiously with its great tail, showing every sign of disappointed rage. 
I46 THE WILDERNESS AND JUNGLE

\section{AFRICA}

If we still call Africa the "Dark Continent," it is from force of habit, for this is no longer anything but a courtesy title that has survived from the days of Livingstone and Mungo Park. Africa has long since been brought within reach of the tourist. Ladies even travel alone beyond rail-head in machillas, i.e. litters carried by native bearers. The Uganda Railway affords intimate glimpses of the Great Rift Valley and its big game, and it will not be long, at the present rate of development, before we have the Sleeping Car Company running week-end trips to Timbuctoo. Busy cities, with telephone and electric light, stand to-day where, fifty years ago, pioneers camped in the wilderness and heard the lion roaring for his prey. All this opening up of Africa by those who dig for gold or diamonds has not been without its effect on the wild life, which has been driven back, little by little, until, even within the memory of Selous and other living sportsmen, the buffalo and antelopes have forsaken haunts in which, not many years back, they still abounded. Nevertheless, in spite of the inexorable march of civilisation, which, in the New World, swept the buffalo and Red Man off the prairie in order that Americans might grow wheat to cram the elevators on the 
lake shores, Africa is still a marvellous museum of living specimens. It is not many years since its forests yielded the okapi, a large beast, suggestive of zebra and giraffe in one, hitherto unknown to Europeans and a mystery even to the natives. Many African animals, including the hippopotamus, zebra and giraffe, are found nowhere outside of the continent.

The spell of the African forest is distinct from that of the jungle in India. The equatorial region is more mysterious and further from civilisation. India has been under European rule for more than a century. Its jungle supports a dense human population, and the natives, though superstitious as all Eastern races are, know a good deal of the wild creatures and their ways. Railways penetrate in all directions, even high into the hills. There is a little insect in Africa known as the tsetse-flythere are several kinds, but I refer to the one associated with the terrible disease known as sleeping sickness-which must always, so far as we can see at present, exclude Europeans from thousands of square miles, but there is no such scourge in India.

Even where this poisonous carrier of infection is unknown, the climate of Africa is, in many parts, almost intolerable. It is less a question of darkness than of glare. Then, again, the natives are in every respect, save 


\section{I48 THE WILDERNESS AND JUNGLE}

that of colour, different from the Indians. Most of them are negroes. Their knowledge of natural history amounts to very little. A few make brave and skilful trackers of elephant or lion, but of the habits of wild animals the vast majority know little and care less. They would rather have them dead than living, for they eat every bird, beast, and reptile in the land, and the traps in which they capture them, from the great hippopotamus down to the smallest gazelle, are primitive and cruel. Of the arts of taming wild creatures and making them perform useful work they have no notion. Cattle, sheep, and goats they keep, of course, and occasionally one hears of a wild dog being trained for the chase; but as for training an elephant to haul timber, or a cormorant to catch fish, they would scoff at the idea. Elephant and cormorant alike go into the pot.

Different as are the wild animals of the two regions, they have also some features in common. Each has its lion, leopard, rhinoceros, buffalo, wild boar, and monkeys. On the other hand, India has no giraffe, and Africa no deer. India has no zebra, and Africa no bear. India is poor in antelopes, but rich in wild sheep. Africa has but one wild sheep (of no great account), but a grander assemblage of antelopes than all the other continents put together.

But that this book aims at giving most of its 


\section{CREATURES OF THE WILDERNESS 149}

space to those creatures which, for purposes of sport, we call Big Game, first place in any account of African animals should belong by right to the great manlike apes, the gorilla and chimpanzee, the long-armed gibbons and dogfaced baboons. These "wild men of the woods" are, with the red-haired orang-outang of Borneo, the most human of all the lower animals. They are consequently of supreme interest to every naturalist who recalls the poet's injunction that "the proper study of mankind is man." In one respect, indeed, the apes even have the advantage. They are not four-footed, but four-handed, a boon which is best appreciated at moments when, with both hands full, we find ourselves seriously handicapped for want of a third. Christmas shopping may be suggested as one of the occasions on which two or three more hands would be welcome. The apes do not go shopping, but they are able, at any rate, to move at great speed in the tree-tops, swinging from bough to bough with a grace and agility that must be seen to be believed.

The most familiar monkeys in South Africa are the baboons, terribly destructive brutes, killing sheep, goats, and poultry wholesale, and damaging standing crops beyond all hope of recovery. So costly are their depredations that every now and then the farmers are com- 


\section{THE WILDERNESS AND JUNGLE}

pelled to muster and to slaughter all the baboons they can find, just as the farmers of Devonshire organise shooting parties in the spring to slaughter the woodpigeons that eat their young clover. An old male baboon is a savage customer absolutely devoid of fear. One of these animals has been known to enter a lonely farm building in broad daylight, and when a fierce mastiff was sent to tackle the intruder, it was the dog that got the worst of the encounter. No one will blame the farmer for destroying these greedy and dangerous neighbours of theirs, but even though not sacred as in India, monkeys should never be shot for sport. They are, above the majority of small animals, interesting to watch, and there is, or should be, something sympathetic about a monkey, whether in its native tree-tops or on a hand-organ. Moreover, these alert and nervous little creatures are at times of service to the sportsman, for, ever on the look out for danger, they are quick to notice the least movement of a leopard or other dangerous animal in the undergrowth, and their frightened chatter frequently betrays the whereabouts of big game that might otherwise escape notice.

\section{THE LION AND LEOPARD}

The grandest animal in all Africa, indeed the acknowledged king of beasts, is the lion. 
CREATURES OF THE WILDERNESS I5I

Its black mane (there are maneless lions as well) and splendid head give it a noble appearance, which has perhaps inspired poetical notions of its character; but a full-grown lion, measuring, it may be, nearly six feet along the body, with another three feet of tail, is, to my mind, a more imposing sight than a tiger. Yet comparisons between the two are perhaps unnecessary. There is room in the world for both, and it is only in Persia that the two meet on common ground. Those who prefer to regard the Bengal tiger as the more royal beast of the two are free to do so, and the impression of its sovereignty owes much to the superstitious reverence in which it is held by the natives of India. The negro has his debil-debil and his voodoo, but he has no such veneration for Nature as we find in the more sensitive and intelligent people of India. He will run from a lion as fast as his legs will carry him, but veneration is no part of his character.

The cowardly behaviour of the tiger, which is rarely known to give battle without provocation, is too generally admitted to need further evidence. It seems to be less widely known that the lion is also capable of showing the white feather at times, and it may be of interest to give one or two stories in which the king of beasts has shown himself anything but a king. 


\section{THE WILDERNESS AND JUNGLE}

Colonel D. F. Lewis, C.B., tells me that he was travelling in the Sudan one night in February, 1903, with a small caravan, consisting of twelve donkeys, eight mules, two or three armed Sudanese, and half a dozen transport servants. Suddenly, at about eleven p.m., when the moon was rising over the scene, a lion crossed in front of the caravan, not more than forty yards away, and stood gazing at it. Colonel Lewis halted the caravan, but being unable in the dim light to see the foresight of his carbine, he would not fire for fear of merely wounding the animal and endangering the life of his followers. The lion, having satisfied its curiosity, walked quietly off into the forest. Yet, after all, this experience does not show the lion to be a greater coward than its Indian cousin, for the average tiger would not have come out of hiding at all until the caravan had passed. Not the most desperate and famished man-eater in the Indian jungle has ever been known to display the same cunning and audacity as the famous lions of Tsavo, one of which actually dragged a sleeping man through the window of a railway carriage. Both lions and tigers doubtless differ in courage, and one may be more careless of danger than another. There are, however, occasions on which even lions seem to recognise man as their master. A sports- 
man suddenly found himself face to face with four full-grown lions. He dared not fire, for at most he might have killed one of the party, and, for aught he knew to the contrary, the others might have set upon him to avenge their comrade. So, with extraordinary presence of mind, he unstrapped his field-glasses, rushed at the lions with a loud yell, and flung the glasses at them. So terrified were the brutes by his extraordinary behaviour that all four turned tail and bolted into the bush. It must have needed remarkable nerve to run towards four lions in this way, and anyone less brave would have fired wildly at the lions or run away from them, either of which mistakes might have cost him his life.

Another adventure of the kind, still more desperate in some ways, befell Mr. Percy Reid. He had fired at a lioness and wounded her, having mistaken her, in the long grass, for an antelope of some kind. Next moment, to his horror, out came the wounded lioness, with two others and a lion. Here, indeed, was a pleasant moment, the kind of moment in which a man sees all his past. The wounded beast charged, but for some reason she swerved to one side and missed him, looking over her shoulder and growling savagely as she went by. Then the others moved away. Mr. Reid asked Selous what he would have done in the 


\section{I54 THE WILDERNESS AND JUNGLE}

circumstances, and that mighty hunter gave it as his opinion, from long and unique experience of these animals, that if he had managed to shoot one of the animals dead, the rest would in all probability have bolted, but that if he had only wounded it badly, they would have been just as likely to charge.

Perhaps the most convincing case of cowardice in lions is one for the story of which I am indebted to Mr. H. C. de la Poer (of the Warwickshire Regiment), and which may be told in his own words :-

"One morning, about eleven, when shooting in the Northern Territories of the Gold Coast, I climbed a steep, rocky hill to get a better view of the bush-covered plain below, and on reaching the summit, moving silently over the rock in felt-soled boots, I blundered right into a small party of lions asleep. The lion, with one lioness, jumped up and trotted behind some boulders about ten yards further on. As my gun-bearers were some distance behind, with both my rifles, I could do nothing but stand there and gape; and while I was thus occupied, a second lioness rose, literally at my feet, stretched herself, gave me a long stare, and finally walked slowly in the direction taken by her companions. When she had gone a few yards, however, she stopped, turned broadside to me, and stared again. By wagging my hands furiously behind my 
back, I managed to bring up one of the men with a rifle, a single-barrelled weapon which, in view of the presence of other lions, I preferred not to use first. My soldier orderly had to make a second trip to get the other, a double 450 , for the other gun-bearer was too scared to bring it himself. All this time the lioness kept her position, showing no sign of uneasiness, and not even stirring when I took a step forward and sat down on a stone so as to take steady aim. The shot knocked her, dying, down the hillside, and at this the other two began growling and 'wuffing,' but, to my disappointment, they did not show up. I gave them a few moments' grace, and then went very cautiously in their direction. Coming round a huge boulder, I came suddenly on the lioness, but could see only her tail, the rest of her being hidden behind the rock. The tail was nearest to me, but just as I caught sight of it it gave such a swing that I feared the lioness must have turned and might be waiting to strike me down as I passed. In order to avoid this, I turned back and climbed the boulder quickly in the hope of seeing her below me, but, alas, I never saw her again. Almost immediately, however, we had a view of the lion trotting away in the plain below, some two hundred yards away, but the bush was so thick that a shot was out of the question. I saw him once again, some three or four hundred yards away, and, marking him as best I could by the trees, I left the hill and ran after him, but the grass was very 


\section{THE WILDERNESS AND JUNGLE}

high, and I saw no more of him until, a long way off, I saw him bounding along clean through a herd of hartebeest, which made way for him, but faced him, heads lowered."

This curious and interesting experience shows that some lions at any rate think discretion the better part of valour. Well, other kings have done the same before now!

Just as a cow-elephant is more likely to make an unprovoked attack on man than a bull, so a lioness is far more likely to fight for her consort than her consort for her. Acting on this wellknown fact, Sir Henry Seton-Karr recommends anyone coming on a lion and lioness together to shoot the latter first. If the lion be killed, the widow usually charges at once; but the death of the lioness is not always resented in such violent fashion by the survivor.

I have to thank Mr. Percy Reid for two other stories, of which the first, at any rate, shows the lion in a character anything but heroic. Still, this may have been a cowardly lion, and anyone who should emulate the recklessness of $\mathrm{Mr}$. Reid and his companion might, with a braver individual to encounter, pay for his temerity with his life. Mr. Reid was out one morning along the banks of the Majdi River and presently he saw, silhouetted on the horizon, what at first glance he took to 


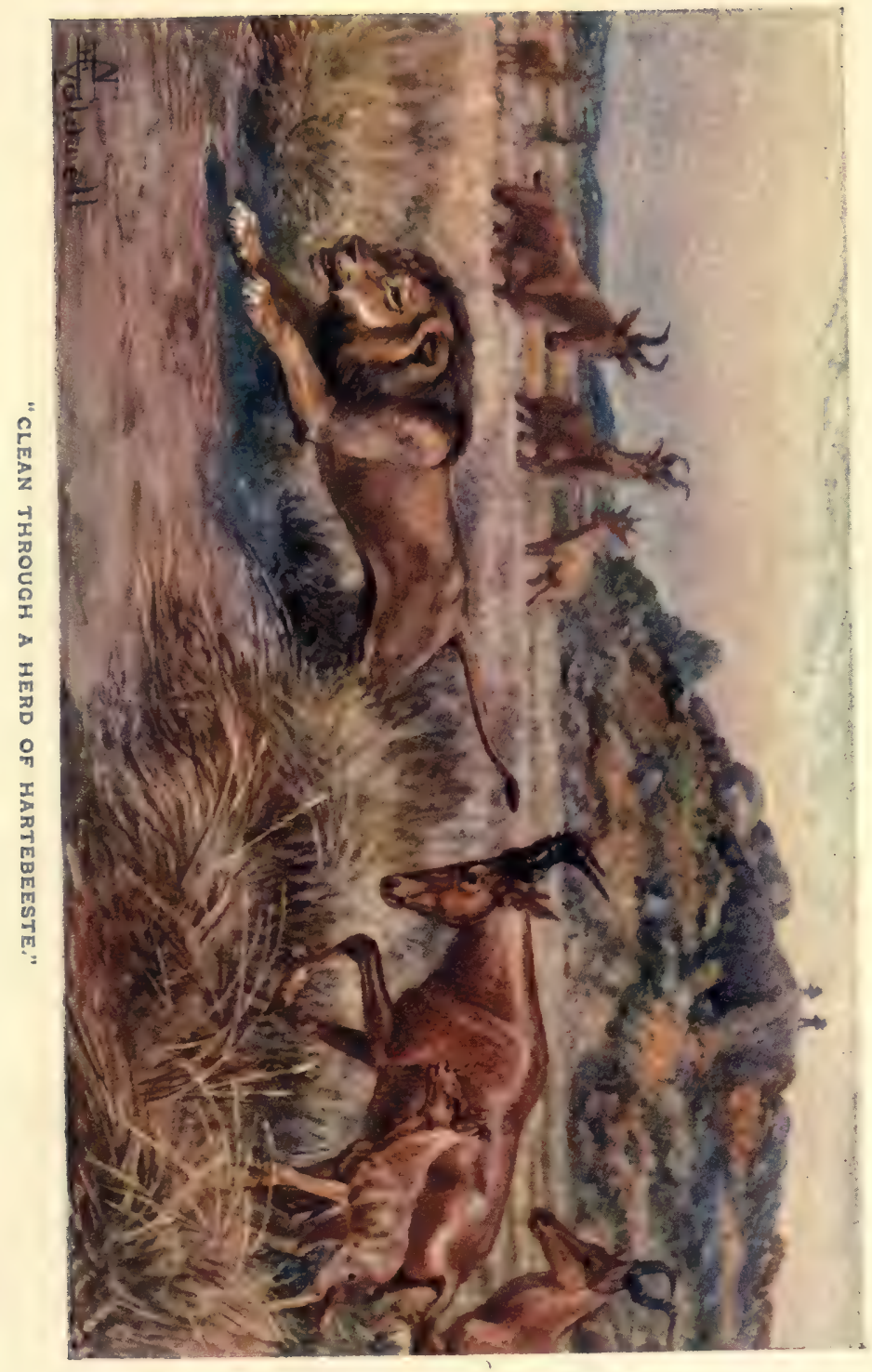





\section{CREATURES OF THE WILDERNESS I57}

be a fine wildebeest, as it had the curious appearance of being all neck and shoulders familiar in that eccentric-looking antelope. On looking more carefully, however, Mr. Reid saw that what he had taken for a wildebeest was in reality a magnificent lion, evidently returning from its night's hunting to lie up in one of the reed-beds at the river-side. He ran along with the object of cutting off the lion's retreat, but it was too quick for him, and he had only time for a hurried shot at about I 20 yards range, at the moment when it reached shelter. He distinctly heard the thud of the bullet, and the wounded lion sprang into the reeds with a loud grunt. It was obviously useless to follow it alone into its hiding-place, so he went back to camp and, with a friend, turned out the dogs and native boys, the latter numbering about forty and being armed with knives and assegais. The sportsmen had their rifles, and the whole company set out to beard the lion in his den. Mr. Reid reminds me that all this happened many years ago, when he was young and hasty, and I am bound to confess that he and his friend seem to have behaved on this occasion with a want of caution which, with the average wounded lion at bay, would have given them a poor chance of escaping with their lives. The reed-bed was an isolated patch covering rather more than an 


\section{I58 THE WILDERNESS AND JUNGLE}

acre, and the stems stood ten or twelve feet high. The first proceeding was to guard every likely exit through which the lion might break and to send the dogs in after it. The fun soon began; lion roaring, dogs baying, and every moment the men posted outside expecting the furious animal to charge. But something quite different happened. A sharp yell of pain came from one of the dogs, and out came the pack with their tails between their legs. They had had enough of it. Only one, the best hound of them all, stuck to the enemy, and he, poor brute, presently limped in view with his back broken. It is not surprising that, after such an experience, nothing would induce the dogs to face the lion again, so Mr. Reid and his friend decided that there was nothing for it but to go in after the lion themselves. A start was made, and the plan determined on was to cut two main paths at right-angles and then to beat each quarter of the covert in turn. Cutting down those tough reeds, each the thickness of a man's wrist, was laborious work, but half a dozen of the boys went at it with a will, the two Englishmen following at their heels, rifles cocked and senses alert. When the party had got about half way, a terrific roar shook the reeds, and back jumped the boys, all but knocking Mr. Reid and his friend over in their anxiety to get 
away, and flinging their assegais about with so little regard for what they might hit, that there was worse to fear than the lion, which never once showed so much as its nose. They spent the whole day in that reed-bed with the brute, which often made itself heard, but was never seen. Once, indeed, it did break a short way out of covert, but quickly turned in again. And so the sun went down, the party were dead tired, and they had to give it up, hoping that the lion might still be in possession next morning. They were back again at daybreak, but the lion's tracks were now seen leading unmistakably away from the reedbed, and, although they followed the spoor for a mile or more, they never set eyes on the animal again. That particular lion was unquestionably a coward, believing in the policy of living to fight another day, and on this account the more interesting by way of contrast with the many lions that have faced tremendous odds and died fighting.

On the second occasion, Mr. Reid was luckier, though here also he ran great risk of being mauled, if no worse. It was in Barotseland this time, and about the hour of sunset. He was sitting in camp and had, in fact, replaced his boots and gaiters with a pair of slippers, previous to cooking his supper, when one of the camp boys came running up with 
160 THE WILDERNESS AND JUNGLE

the pleasing information that lions were after the donkeys. Snatching up his rifle and cartridge-belt, he ran off, followed, as luck would have it, by three or four of the dogs, which took up the scent of a lion before they had run a couple of hundred yards and dashed off full cry into the bush, with Mr. Reid at their heels. As he proceeded, the bush became thicker and thicker, and at last he had to stoop and crawl under it as best he could. It was so dense, indeed, that he could only push on with the greatest difficulty, though he could hear the dogs baying the lion in the distance. More than once the lion managed to break away from them, only to be brought to bay again a little farther on. The light was failing by now, and Mr. Reid was just thinking of giving up the hunt when he realised, from the sounds of the fray, that he must be getting very near, and suddenly he came on a fine lioness lying facing him, under a bush about ten yards away, with the dogs round her. It was much too dark to see the rifle-sights, so he took the best aim he could and fired. Fortunately, the bullet caught the lioness in the mouth and dropped her dead where she lay, but, with a less lucky shot, the result of the encounter might have been very different.

It might have been thought that the disturbing spectacle of a man on a bicycle would, in 
the old days, at any rate, have been enough to send most wild beasts, even lions, into hiding. If I remember right, a well-known traveller in Morocco, who is now dead, once bicycled right against a wild boar and was charged. Nowadays, no doubt, with the opening up of Africa, even the rare and timid okapi is familiar with the sight of cyclists, but twenty years ago a bicycle must have been an unusual apparition in the African forest, and it was about that time that a cyclist had a very narrow escape indeed between Blantyre and Namazi. The story was as follows : It was late in the evening and darkness was falling swiftly, as it does in Africa, with only the faint illumination of a young moon. The man had dismounted and was pushing his machine uphill, when, suddenly, he heard a heavy animal of some kind moving in the bush close to the road. He thought that, at the worst, it might be a buffalo moved by curiosity to keep step with him, as these animals sometimes will. Still, the sensation of any wild animal of such size so close to him was sufficiently unpleasant to make him hurry as much as was possible on a bad road. When he was about half way up the hill, something prompted him to look round. It was well that he did so, for there, standing broadside across the trail and looking straight at him, was a full-grown lion. Even as he looked back, it 


\section{THE WILDERNESS AND JUNGLE}

charged, growling savagely as it came bounding up the road. He made a frantic attempt to mount his bicycle and failed; then failed a second time, the lion gaining on him all the while; and at last succeeded, though the machine wobbled so from side to side that the distance between man and beast dwindled every minute. After what seemed an interminable delay, he reached the top and flew down the other slope, his machine finally jumping a culvert, on coming to which the lion fortunately gave up the chase. It was, however, a near thing, and the cyclist made up his mind to indulge in no more moonlight rides in that neighbourhood.

Even the motor-cycle has no terror for the lion. A lady and gentleman, riding on these machines in Central Africa, were recently chased by two of these animals over a distance of five miles. The lions showed no fear whatever of the noise made by the engines, but galloped after them with evident intent to kill. The riders outdistanced them and eventually reached home much shaken by so trying an experience.

Like its little cousin, the tame cat, the lion keeps its claws sheathed except in battle, so that its footprints never show the claw-marks. This fact has not always been honoured by artists in their realistic pictures of wild life, but 
they would do well to take note of it so as to escape the reproach of having tracked their lions only in the studio. The lion's roar does not impress everyone alike, since some of us are more sensitive to sound than others. Thus, some folk are curiously disturbed by the scritching of bats, while others do not even hear it. Much of the terror commonly inspired by the voice of the lion depends on the circumstances in which it is heard. Those who hear it in the Zoo, knowing themselves perfectly safe, cannot be troubled by it as were the Christian martyrs waiting for their dreadful death in the Roman amphitheatre. Heard at night in the forest, or on the veldt, its vibration shakes the earth, yet some travellers have found it no more terrible than the booming note of the ostrich, and even in the lower animals familiarity with lions may soon breed contempt. The elands and buffaloes that live in the paddocks close to the Lion House in the Zoological Gardens at Regent's Park munch their hay, perfectly indifferent to the terrific roaring close by, paying no more attention to it than they do to the strains of the band, though on their native veldt such music would send them scampering in headlong flight. The lion has several notes, purring on ordinary occasions like the great cat it is, but, when angry or wounded, coughing and "wuff- 


\section{I64 THE WILDERNESS AND JUNGLE}

ing " in much the same way as the tiger. Like other cats, it stalks its prey in silence, creeping and circling till close enough for the final spring. When one lion roars in the night, another often takes up the proud challenge. Then, like rival stags in a Highland glen, they may meet and fight it out. Colonel Andrew Haggard, D.s.o., tells a good story of how, on one occasion, in Abyssinia, this habit of answering the challenge nearly brought about a disaster in his camp. He had with him at that time an Egyptian staff officer, who bragged so continuously of his own bravery, and more particularly of his disdain for lions, which apparently had no terror for him, that the other natives, tired of always having to listen to this self-praise, set a trap for him. It so happened that one of the Colonel's Abyssinian servants was a wonderful mimic, and his repertoire, an extensive one, included a remarkably realistic imitation of a lion's roar. This suggested an opportunity of putting the valiant Egyptian's boasted courage to the test. One night, when the party were seated round the camp fire, a terrific roar suddenly sounded out of the darkness only a few paces away. So real was it, indeed, that even Colonel Haggard, who had been waiting for it, and who had also, by way of precaution against stampede, had the goats and camels tied up, gripped his 
CREATURES OF THE WILDERNESS 165 revolver. As for the Egyptian, he fled into the night, leaving the party convulsed with laughter. So far, all had gone well, and everyone was much pleased with the not unforeseen result of the experiment. Then the laughter suddenly ceased, for another roar. even more terrible than the first, sounded close to the camp. The ventriloquist had been sitting with the rest, but he was now as panic-stricken as they, for this time it was a real lion that had taken up the challenge, and he was the last to appreciate so practical a tribute to his talent for imitation. Fortunately, the brute was driven off before doing any mischief, but the evening's comedy might easily have been turned to tragedy.

Although the lion may ungrudgingly be acclaimed the king of beasts, there is no need to believe all the rubbish written about its nobility of disposition and, in particular, its alleged reluctance to kill an unarmed man. It is neither noble nor magnanimous, nor has its life on the veldt taught it any belief in plain living and high thinking. It is just a cat that hunts zebras, or even an occasional young hippopotamus when it can find one on land without its parents, instead of mice, and it is often a hungry cat-savage, greedy, and cunning.

Lions are partial to a young giraffe, but as 


\section{I66 THE WILDERNESS AND JUNGLE}

the two do not flourish in the same parts of Africa, the giraffe liking dry desert, where water is too scarce for the comfort of lions, they cannot often gratify their taste. Mr. H. A. Bryden tells me that full-grown giraffes, like other heavy game, sometimes manage to dislodge lions that have leapt upon them by brushing them off against the timber, and he saw one giraffe, at any rate, which showed unmistakable signs of such an encounter. The most extraordinary case of escape from lions was that of the giraffe seen by the great hunter of the eighteen-fifties, Andersson. It was attacked by no fewer than five lions at once, but was rescued by his natives, who drove the lions off.

The African leopard has much the same habits and appearance as its Indian namesake, and, unless it be slightly smaller, may be regarded as the same animal. It is, as in India, the most destructive of all big game, and kills sheep and goats for the sheer pleasure of killing, and without any thought of eating its victims. The natives therefore hate it even more than they do the lion. A whole flock of sheep may be found dead at daybreak, each animal with a single bite in its throat and not one of the number devoured, the marauder having just slaked its thirst for blood and gone 
CREATURES OF THE WILDERNESS 167 its way. It is not surprising, then, in view of its habits, that gun, trap, and poison should be employed against it. Yet, although given to slaying farm stock in this way, it will, in the jungle, return to a kill again and again in the same way as the lion and tiger. The only animals which we know to act differently are the hunting-dogs, which, after eating a small portion of each kill, commonly leave the rest to the vultures and go after other prey. The leopard is, as has been said in connection with these animals in India, quite distinct from the cheetah, or hunting-leopard, and the two are, in fact, sworn foes. A fight between them was once witnessed in the Government Game Reserve on the Crocodile River. The cheetah appears to have killed an antelope and was eating it when a leopard came on the scene and killed the cheetah in its turn. The African cheetah seems to be even scarcer than its Indian namesake and is rarely encountered by sportsmen, though one was shot during one of Lord Delamere's trips in Somaliland.

\section{HUNTING-DOGS AND HYENAS}

The hunting-dog, which ranges over Africa from the Sahara to the Cape of Good Hope, is at times even more destructive than the leopard. These animals vary so much in 


\section{I68 THE WILDERNESS AND JUNGLE}

colouring that, in fact, hardly two can be found, even out of the same pack, exactly alike. When on the trail they show the same indifference to the presence of human beings as the Indian dhole, and occasionally they even attack natives. On the other hand, cases have been known in which the negro, as an exception to his curious incapacity for taming wild creatures, has captured a young hunting-dog and trained it (like the Indian cheetah) to course antelopes. These dogs hunt their prey chiefly at night and entirely by scent, but they have also been seen chasing antelopes in broad daylight. They will run down the heaviest roan or sable, hunting mute and snapping at the fugitive's hocks till at last they are able to pull it down. The natives of the Gold Coast credit the huntingdog with great courage and ferocity. Once, they say, a pack gets on the trail it never leaves it until it has killed, and they go so far as to assert that even lions and young elephants are hunted by these brutes. It may be that, owing to the scarcity of hunting-dogs in that region of Africa, they assume the terrors of the unknown in native eyes; but Mr. de la Poer tells me that he knew of one native, at any rate, who had been hunted and treed by them, and he himself had an encounter with a pack which was quite exciting enough for the average taste. He came on about forty 
of them unexpectedly when they were lying down round a roan antelope that they had killed, and the whole pack immediately surrounded him and his orderly, snarling, barking, and making little jumps towards him, but never coming nearer than seven or eight yards. $\mathrm{He}$ was, as he readily admits, thoroughly scared, and no wonder, for, as his second gunbearer had bolted at the first alarm, he had only one weapon - a single 400 - and, as anything short of a Maxim would have been useless against such numbers, it would have been madness to fire. After about ten minutes of what seemed interminable suspense, they drew off, and he bagged one at ninety yards. On his return to camp, the dogs followed and made a ring round the men of about three hundred yards radius, calling to each other incessantly with a note much like a foxhound's. Then, at last, they cleared off. Mr. de la Poer quaintly remarks that, in his opinion, if they had not had their kill, his orderly's invocations to Allah might not have been heard in time.

Of hyenas Africa has three kinds-spotted, striped, and brown-all of them less attractive even than the hunting-dogs, since they are cowardly brutes, terrified of man, though bold enough to kill a sleeping native. Like the kea of New Zealand, hyenas have learnt their 


\section{7o THE WILDERNESS AND JUNGLE}

taste for mutton from opportunity, for before such food was to be had on the veldt they must have been content with carrion. These hideous ghouls always gather in the wake of retreating armies. Large numbers appeared along the line of march when the forces of the Mad Mullah were retiring before our caravans, and when the bloodthirsty Zulu chief, Chaha, had in the course of his depredations, laid waste vast areas of South Africa, hyenas simply swarmed over the battlefields and feasted on the naked dead. In the ordinary way, hyenas are creatures of darkness, but they are sometimes seen abroad during the day. Major Kennard once witnessed a terrific battle between two striped hyenas in India, in a nullah not far from Muttra. So occupied were the combatants with each other that they took no notice whatever of him, so he shot one of them dead. Then the other began to worry it, and he shot that as well. This curious failure of instinct is very common in wild animals that fight in presence of man and allow themselves to be shot rather than take the more sensible course of forgetting their quarrel for the moment and escaping from the common danger so as to fight it out in safety another day. The case of duelling stags is a familiar one, and many a fight to the death has been witnessed by keepers in the High- 


\section{CREATURES OF THE WILDERNESS I7I}

lands. Where hyenas feed, there also gather the vultures. I have seen them come round a carcase in the most astonishing fashion, dropping out of the blue sky in a few minutes, though there was no sign of one before. Either the eyesight of these scavenging birds must be something quite beyond our conception, or else they are gifted with some sixth sense of which we know nothing. The fact remains that unless a newly killed animal is instantly and effectually concealed under branches, the vultures are certain to mark it for their own long before it is cold.

\section{THE AFRICAN ELEPHANT}

In considering the appearance and habits of the African elephant, it will not be possible to treat the subject at the same length or from the same point of view as in the case of its Indian cousin, for, unfortunately, our attitude in respect of the two is quite different. The Indian elephant has long been the faithful servant of man, and, from close association with its mahout, much of its life is an open book. In consequence, there are numerous interesting and authentic stories of its memory and sagacity, such as those related on an earlier page by Sir William Lee-Warner. The African elephant does not come before our eyes in the same intimate fashion. It has, unhappily, 


\section{THE WILDERNESS AND JUNGLE}

been regarded by mankind chiefly as the source of ivory, and has been killed first and studied afterwards, so that, while we know something of its body, its mind is shrouded in mystery, and whether it be more or less intelligent than the Indian kind none can say from experience.

Reference has already been made to the fact that, in spite of the word maximus being the approved scientific distinction of the Indian species, it should by right belong to the African, which is much larger. Thus, the worldrenowned "Jumbo" stood I I feet high and weighed $6 \frac{1}{2}$ tons, and wild elephants standing I $1 \frac{1}{2}$ feet have been recorded from Abyssinia. More attention has been given to the length and weight of the tusks, which have been taken measuring over II feet and weighing upwards of $230 \mathrm{lbs}$.

Something has already been said of the differences between the two kinds, and by way of recapitulation it may here be mentioned that the chief points to note in the African elephant are--

Larger size,

Larger ears,

Longer and heavier tusks,

Females bearing tusks equal to those of the males,

Trunk less tapered and with two "fingers" instead of only one. 
The African elephant is said by those who know both to be much fiercer and more savage than the Indian animal, which is hardly to be wondered at when we remember that the moment an African elephant is seen outside of a Government reserve it becomes a target for all and sundry, native and European alike.

It is a great traveller in search of food, and its wanderings take it high above the plains and far up the green slopes of Mount Kenia. It is also a coarser feeder than the Indian kind, using one of its tusks, generally the right one, to prise up mimosa and other trees, from which it then strips twigs, leaves and bark. Its huge ears, at all times conspicuous, assume a frightful appearance when it is charging, for they then stand out at right angles to the head like the wings of some angry demon, and at such moments its trumpeting is nothing less than deafening. Its powers of eyesight and hearing are only moderately developed, but it has a very keen sense of smell and must be stalked very carefully upwind. If suddenly disturbed at close quarters, it is apt to charge before a shot is fired, and on such occasions the female is considered the more dangerous of the two.

In some parts of Africa, elephants with only one tusk are not uncommon, and these are invariably the worst-tempered in the herd, per- 


\section{THE WILDERNESS AND JUNGLE}

haps because they smart under the handicap imposed on them by the want of a second tusk, or possibly from actual pangs of toothache.

Mention has been made of the fact that, in the ordinary way, elephant-shooting is no longer permitted in India, and even in Africa the Powers, waking, as is their habit, a little late to their responsibilities, are at last framing regulations to save the remnant of these splendid animals. In some districts, however, the big game hunter may, after taking the prescribed licence, still enjoy the supreme excitement of an encounter with the greatest animal on earth, running risks that not even the most perfect rifles can ever quite eliminate, and Major V. R. Whitla sends me the following account of a "right and left" at these animals in North-Eastern Rhodesia, from which it will be gathered that he did not get his ivory for the asking :

"One Christmas, not long ago, I was camped near Ndombo's village in North-Eastern Rhodesia. I had left Broken Hill, just over two thousand miles from Cape Town and at that time the terminus of the railway, early in July, and, after a very pleasant six months up country, was now on my way down to Mpika, from which spot a three weeks' march would take me back to Broken Hill and civilisation. The heavy rains had set in on December 12 , turning 
every small stream into a howling torrent and so spoiling the shooting that I had decided to go back. One morning, however, saw an abrupt change in all my plans, as my tracker, a local savage named Makale, brought me word that two of his friends had seen three big bull elephants a day or two before at a place not much more than twenty miles east of where we were encamped. I confess that, just at first, I was much inclined to doubt the story, as Makale, who had been with me about a month, had proved himself not only a first-rate tracker, but also a persistent liar. The friends were, however, produced and strenuously crossexamined separately by my headman Benjamin, and their accounts agreed so accurately that there seemed no further room for doubt.

"The first step was to take out a new licence, costing $\&_{25}$, as all game licences in that district expire on December $3 \mathrm{r}$, and this entailed two long marches to Mpika, one of the stations in North-Eastern Rhodesia at which licences are issued by the authorities.

"The next thing, which proved more laborious, was to get across the Nyamadzi River, then in full flood, as the elephants had been sighted near a village called Kafwimbi, about twenty miles away on the other side. At other times of year this river may be forded without difficulty, but the heavy rains had swelled it to formidable proportions, and, as no dug-out was to be had locally, there was nothing for it but to build a boat for ourselves. My men set to, selecting a particular tree with thick 


\section{I76 THE WILDERNESS AND JUNGLE}

but flexible bark, and then removing a piece of this bark of the required length in one piece without felling the tree. The ends were then folded across and sewn together, the crevices being filled with clay, a split bamboo being sewn round the top to form a gunwale, and two or three cross-pieces being attached to stiffen the frame and lessen any tendency to collapse. As a result of this ingenious carpentering, I was presently in possession of a light and watertight canoe, about I 2 feet long and 3 feet broad, capable of holding six or seven men. At the first launch we found that the current was too strong to allow of either poling or paddling, but my porters soon rigged up a long rope of plaited bark, which was fastened to trees low down on either bank by a man who managed to take one end of it and swim across, and by this means we got the porters and their loads across without accident.

"We now had to make two marches to Kafwimbi, as the going was bad, several streams, insignificant during the dry season, being now so big that it was found necessary to halt while trees were felled and laid across. On the second day's march I came upon fairly fresh spoor of cow elephants, as well as fresh spoor of three rhinos, which are common in that part of the country. These, however, we did not follow, as I did not want to frighten the elephants away by firing at other game.

"On reaching Kafwimbi's, I interviewed the chief, who told me that some of his men had seen the spoor of a very big bull elephant not 
far off the day before, and he offered to come with us next day to show me the ground.

"Next morning I was called at 4 a.m., but it was raining heavily, so that I did not make a start until 7 , by which time the rain had ceased, though the sky looked threatening. Up to Io, we could find no fresh tracks, but we then met two natives who, in going from one village to another, told us that they had crossed fresh tracks of three bulls only about a mile back. We set off in that direction, and easily picked up the spoor in the soft ground. Owing, however, to the quantity of rain that had fallen during the night, it was hard to say exactly how old it was. I judged it to be not more than from twelve to eighteen hours old, and well worth following up, particularly as one, at any rate, was the spoor of a very big bull, the prints of his forefeet measuring just over $2 \mathrm{I}$ inches from toe to heel, whilst the other two measured 18 and $18 \frac{1}{2}$ respectively.

"Owing to the water-logged state of the country, the going was bad and tiring, and much time was lost in crossing the numerous streams in our way, but the spoor was very plain and we were never at fault. After going a few miles, we came to a low bank of soft earth which bore the distinct impressions of the bodies of all three elephants, showing that they had rested there during the night or very early that morning. This was a very interesting sight to me, as I had often been told by hunters that elephants never lie down to rest, but sleep standing or else leaning against trees. 


\section{I78 THE WILDERNESS AND JUNGLE}

Yet here was undeniable evidence of their lying down, and, as a matter of fact, I had come across similar proof of this habit when tracking a solitary elephant a month earlier.

"After their siesta, the three bulls had moved on, feeding at intervals, as was apparent from the way in which, though always moving in one direction, the tracks kept diverging and recrossing. We stuck to the spoor of the biggest, which was very easy to follow, and kept to it until three in the afternoon, when it was evident from various signs that the elephants were not far away. Soon afterwards I saw an elephant standing in a comparatively clear patch about 200 yards away on our left front, and at the same moment I descried a single zebra grazing his way slowly across this patch towards the forest on the far side. We, therefore, halted immediately under cover, so as to let the zebra move on, as these animals have a most irritating habit, the moment they see the hunter, of galloping wildly round in circles, about 150 yards distant, unavoidably giving the alarm to all other wild animals in the neighbourhood, and spoiling all chance of a shot. This annoying habit is shared by the kyang, or wild donkey, of Tibet and Ladak, which has in such fashion ruined many a careful stalk of mine after antelope or Ovis Ammon.

"It was fully a quarter of an hour before we deemed that the wretched zebra had got far enough into the forest to make it safe to proceed, and during this trying interval the 
elephant must have got slight wind of us, as he twice faced in our direction, with ears cocked and trunk extended, and finally moved slowly off, fortunately up-wind. I had, in the meantime, had ample opportunity of examining him through my Zeiss glasses, and made him out to be a bull of ordinary size with tusks of apparently about $30 \mathrm{lbs}$. each, but I could not see whether the other two were in the forest beyond. I concluded, however, that it was best to follow him, on the assumption that, even if they were not with him, he would certainly be making his way to rejoin them, and this luckily proved to be the case, for when he had gone another mile he suddenly halted in some fairly thick cover, in which I was able to make out the tails and hindquarters of two others.

"I now made the four natives with me go back some distance and sit down, as I knew none of them well enough to trust him with a second rifle, and I preferred to advance alone, carrying my double 400 cordite ejector, towards the cover, which was straight up-wind. As I proceeded, the elephants went slowly forward, and on reaching the spot where they had previously stood, I found that the thick patch extended only some 50 yards farther, and that beyond it lay an open patch of some three or four acres. To my surprise I now saw, standing in this, within about 40 yards of the nearest trees, not three, but four elephants, one of them much bigger than the rest, and evidently the animal whose spoor I 


\section{I80 THE WILDERNESS AND JUNGLE}

had been following the whole day. They were halted in close order, the head and shoulders of the big one being covered from a shot by the body of one of its fellows. I therefore sat down just inside the edge of the cover and examined them carefully through my glasses, and soon made out that they were all bulls. The tusks of the big one were disappointing, and I did not estimate them at over 50 or $60 \mathrm{lbs}$. apiece. Then came a tuskless bull, the first I had seen during six months in that part of Rhodesia. Of the other two, the one that I had first sighted alone seemed to carry short tusks of about $30 \mathrm{lbs}$. each, and the fourth had longer and thinner tusks which would probably weigh $40 \mathrm{lbs}$. each.

"I had to wait about a quarter of an hour at the edge of the clearing before I could get a shot at the head of the biggest, but at last he faced in my direction, and I took aim between the eye and earhole and fired. He fell to the shot, struggled half-way to his feet, and then my left barrel knocked him over again. Until I fired the second shot, the other elephants, which were standing close together, had scarcely moved; but on hearing the second report one of them turned tail and bolted, going nearly straight away from me, while the other two came at a rapid pace right for the little tree against which I was standing. I seemed to be in for a charge by the two unwounded elephants, and the prospect was not a pleasing one, for there was not a solitary tree of sufficient size to have afforded shelter, 
or one that an elephant would not have knocked down without effort. Mature reflection afterwards convinced me that the animals had never meant charging at all, but were merely panicstricken and trying to escape, choosing my direction by mere coincidence. Had they really meant mischief, they would have come on screaming and with trunks curled in the air. They did neither, but came with trunks down and without uttering a sound. All the same, there was no time for these comforting reflections at the moment, for in a very few seconds they were almost on top of me, leaving me barely time to reload one barrel of my rifle, the ejector of which fortunately worked well. I then fired at the chest of the leading bull, the one with the long, thin tusks, with the idea of turning him on one side. The shot was a lucky one, as it went through the trunk and lodged at the juncture of chest and neck. On firing, I jumped on one side, but quite unnecessarily as it proved, for on being hit he stumbled to his knees, then, immediately recovering himself, went off faster than ever, followed, to my intense relief, by the tuskless one. A little later we found him stone dead about 150 yards from the spot, and I afterwards found that, when hit, he had been within ten paces of me !

"It was too late to cut out the tusks that evening, as we were a long way from camp, which I reached, very wet and tired, about seven in the evening, having covered in all some twenty-five miles, much of it through 


\section{THE WILDERNESS AND JUNGLE}

heavy mud. Next morning, my porters, sixty in number, accompanied by practically all the villagers, marched the ten or eleven miles and proceeded to cut up the elephants. I did not accompany them on this occasion, knowing from experience what a disgusting spectacle it would be, and confident also that my headman would see the tusks cut out without injury. They were all away till the following morning, when they straggled back to camp with the tusks and meat. The tusks were as follows :-

Length. Girth. Weight. Big Elephant-Right tusk . 5 ft. $8 \frac{1}{2}$ in. $16 \frac{1}{4}$ in. $5^{2} \mathrm{lbs}$.

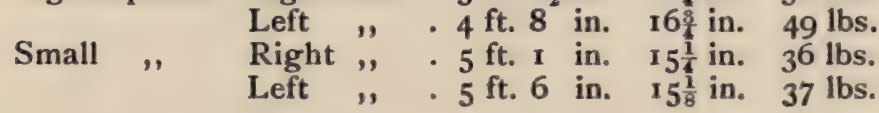

"It must be confessed that the tusks of the big elephant were disappointing, as the animal was an uncommonly big one, and, judging from the appearance of his skin, of great age. They had evidently been broken off at some period, and the left one, more particularly, was very short. On cutting him up, the men found two native bullets of hammered iron in him."

The concluding remark in Major Whitla's interesting story bears out what was said on an earlier page. Few elephants attain any great age without having been shot at and wounded, and these encounters doubtless have their effect on the victim's temper. 
Only one kind of African elephant has hitherto been generally known, but a year or two ago the East African Standard published particulars of a somewhat mysterious "waterelephant," as it was called, discovered by a Frenchman in a lake in the Congo. It seems to be of smaller build than the ordinary kind, with short ears and no tusks. Further evidence, however, seems desirable before taking this creature very seriously, though, in view of the recent discovery of the okapi, it is unsafe to predict that Africa may not have other surprises in store.

\section{RHINOCEROS}

There are-perhaps it would be more accurate to say there were-two kinds of African rhinoceros. The white, or square-mouthed kind, also named after Burchell, is all but extinct, and only the black kind survives in any numbers in the wild state.

As a matter of fact, the "white" rhinoceros of Africa no more deserves its name than the "white" elephant of Burma, for it is grey, and the same may be said of the "black" kind. Each of them carries two horns on the snout. In the square-mouthed rhinoceros the fore-horn has been known to measure over 62 in., whereas the longest recorded fore-horn in the black rhinoceros was only $44 \mathrm{in.} \mathrm{In-}$ 


\section{THE WILDERNESS AND JUNGLE}

deed, it is only in South and East Africa that it has horns of even that length. The second horn in both kinds is always smaller and grows straight, whereas the other is curved, usually backward, though in some specimens it points forward. No doubt the animal knows how to turn it to account, whichever way it grows, and, as has been mentioned above, the African rhinoceros uses the horn for tossing its enemy, whereas the Indian fights chiefly with its teeth.

The rare "white" rhinoceros is the taller and heavier beast of the two, standing a little over $6 \mathrm{ft}$. at the shoulder, whereas the largest known black rhinoceros would be several inches shorter. The most conspicuous difference between the two, however, is in neither size nor colouring, but in the shape of the upper lip, a sure clue to the food preferred by the animal. In the black, the upper lip overhangs the lower like a finger. In other words, the animal is "prehensile-lipped," or able to pick leaves off bushes, browsing on acacia and other low trees within its reach. Burchell's rhinoceros, on the other hand, has a square mouth and is a grazing animal, living out on the open plains, and not in the forests which are the home of the other. Its day is done. Its old haunts know it no more, and even Selous, greatest of living hunters, would be puzzled to find one to-day in the length and 


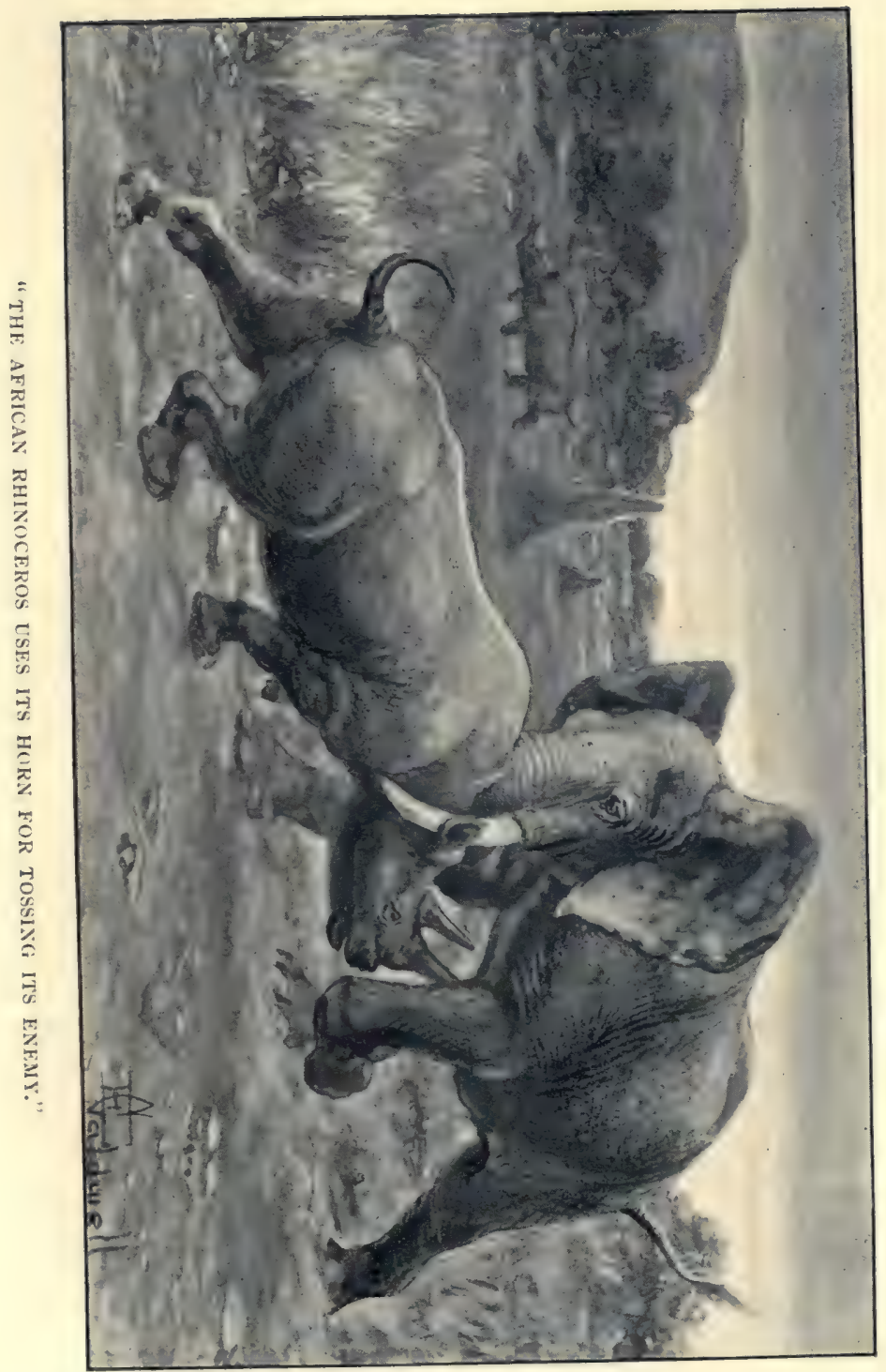



breadth of South Africa. It must be looked for in East Africa, and should be strictly preserved. Unfortunately, Mr. Roosevelt and his son shot nine between them. No one can fairly blame these American sportsmen for availing themselves of the invitation to shoot all manner of game in British territory, but let us hope that those nine may be the last to fall to the rifle for many a long year.

The black rhinoceros may still be described as fairly plentiful as far north as Abyssinia. Those who have shot and watched these animals in the two continents where they are still found (time was, before the dawn of the period we call history, when they roamed over Europe) are unanimous as to their character, describing them as stupid, short-sighted, blundering brutes, much given to attacks of nerves, easily panic-stricken, and at such moments apt to charge blindly the moment they get wind of the hunter, not so much in malice as for fear of being surrounded. There will always be differences of opinion about the character of the lion and tiger, but no such uncertainty seems to invest that of the rhinoceros. Fortunately its eyesight is so poor that its charge can easily be avoided at the last moment.

Much nonsense has been written about the thickness of the animal's hide, which has been 
186 THE WILDERNESS AND JUNGLE

described as capable of turning bullets even at short range, and it may be that these fables date from the days of primitive guns and insufficient charges of powder, which may have had no more effect on these thick-skinned animals than a peashooter on a pig. Modern ammunition, however, makes short work of the rhinoceros; moreover, apart from such vulnerability, we must remember that its hide cannot even withstand the attacks of the tsetsefly, which feeds greedily on its blood. It is, nevertheless, an immensely powerful animal, and few others are so hard to kill ; for it dies so slowly that very often, when one is seemingly dead from spear or bullet wounds, it will rally and either charge the enemy or gallop away out of reach. The rhinoceros is said to be irresistibly attracted by fire. A creature of such bulk hardly seems comparable to a moth flying into the candle-flame, but it is a fact that, attracted in some unaccountable fashion, the rhinoceros sometimes charges right into a camp fire. Elephants have a similar habit of trampling on fires, with the result that they occasionally spread the embers, and have even been known in this way to set fire to native villages. 


\section{HIPPOPOTAMUS}

The hippopotamus is one of those few really ugly beasts in Nature which, if we did not know it to be real, we might think of as a creature seen only in nightmares. When we come to think of it, there are not very many quadrupeds at all events so disgusting to look at. The wart-hog is another, and the Tasmanian devil a third. In its way, however, the hippopotamus is without a rival, since not only is its face, particularly with the jaws open, among the most uncouth in all creation, but, seeing that it weighs, when full-grown, three or four tons, and that its length and girth are about the same, or approximately twelve feet, it has also the most ungainly figure in existence, being, in fact, three times as long as it is high. The hide is devoid of hair and studded with warts. The eyes are small, as are also the ears, which stand erect. Our name for the animal means " river-horse," and the Germans, with their usual passion for detail, call it by a word meaning "Nile-horse" ; yet it is about as unlike a horse as any creature well could be.

There is a much smaller kind in West Africa, a fairy-like creature weighing only three or four hundredweight, and little seems to be known of its habits. The larger species is no longer to be found in South Africa, where it 


\section{THE WILDERNESS AND JUNGLE}

was common in the old days, but still exists in the lakes and rivers of Central Africa, where tourists are unfortunately permitted to shoot it without making the least attempt to recover the body. This wickedness should be strictly forbidden by the captains of steamers on the Upper Nile, whether on Government boats or not. In view of the reception the hippopotamus meets with on coming to the surface, it is not surprising to learn that it spends most of its existence underwater, being able to remain below for five or ten minutes and actually walking on the bed of the river. A man standing on the edge of a swimming-bath with a loaded gun would soon teach even the most reluctant pupil to swim under water, and reference was made on an earlier page to the unfortunate effect which such treatment has had on the once-serene temper of these waterbabies. I have seen it suggested by apologists of the tourist that this is also the work of the trap with which the natives of the Congo and Zambesi regions catch these creatures, a device which, while it would be unpardonably cruel in the hands of white men with firearms, is quite legitimate for unarmed blacks who have to keep themselves from starvation as best they can. This trap is constructed as follows : An immense block of wood, into the heavier end of which is welded a long metal harpoon, 
is hung from a tree over a spot on the bank where these animals are known to be in the habit of coming ashore. A long line, with a buoy at the end, is also tied to the harpoon and a rope is fastened across the path so that the animal, forcing its way past the obstacle, automatically releases the weighted harpoon, which falls on its back and pierces the hide. The unfortunate creature, now in great pain, dashes back into the water and makes frantic but futile efforts to rid itself of the instrument of torture, which, however, sticks fast, like a banderilla in a bull. As its movements under water are betrayed by the tell-tale buoy, it has no chance of escaping from its enemies, who follow in their canoes, thrusting a spear into it whenever it comes up to breathe. Then the end comes, and the great carcase is cut up and divided among the hungry hunters. It is a horrible, if necessary, business, but I do not believe that the practice has spoilt the temper of a single hippopotamus, for the simple reason that the victim never escapes alive. The stray bullet of the tourist is quite another matter, for it wounds the poor beast just enough to madden it and no more. The "sportsman" then goes on his way, and one more furious hippopotamus is added to the long list of those thirsting to avenge themselves on the tyrant man.

The hippopotamus feeds chiefly on the water- 
190 THE WILDERNESS AND JUNGLE

plants of its native river or lake, but it also clambers on shore and makes extensive raids on any cultivated land in the neighbourhood, making short work of any plantation in its path and trampling underfoot what it does not eat. Crops over which a hippopotamus has wandered are of no great value that season. Farmers at home, who cry out now and then when any follower of hounds may "accidentally" cut off a corner of a field, should try a hippopotamus or two. The hippopotamus at the Zoo looks peaceful enough, even when it opens its fearful mouth for buns and biscuits, but it shows a nasty temper at times. I remember an occasion on which it, or its predecessor, killed a terrier that had got into its enclosure. Whether it actually ate the dog, I forget; but if its appetite is as accommodating as that of its cousin the pig, there is no reason why it should not have done so.

\section{GIRAFFE AND ZEBRA}

The extraordinary resources of Africa as a storehouse of strange and interesting wild animals could hardly be more strikingly illustrated than by the fact that it is the only continent producing at once the hippopotamus and the giraffe, the one modelled on a baggagevan, the other an Eiffel Tower of an animal 
and incomparably the most graceful of all big game. The height of the giraffe always astonishes those who see it for the first time, and I always remember the amusing fascination which one at the Zoo had for some Moors whom I once showed round the Gardens, for although natives of the same continent, they had never even suspected the existence of a creature half again as tall as the biggest elephant, or eighteen feet from the ground to the tips of its make-believe horns. The giraffe is, in fact, one of those animals that could never be mistaken for any other, with its brownsplotched skin covering the little imitation horns, the long face and melting eyes, the black tongue, slender legs, and insignificant tail. It is with wild animals as with human beings. Some are full of character, while others are just negative, and on the whole the latter have the happiest time of it.

The large eyes of the giraffe, like those of some fishes which inhabit the abysmal gloom of the deep sea, suggest keen eyesight, and may be contrasted with the large and erect ears of the little fennec which dwells in the same region. Keen eyesight would be useless to so short an animal as the fennec, and, on the other hand, a creature with its nose so far from the ground as the giraffe has little use for highly developed powers of scent, though 


\section{I92 THE WILDERNESS AND JUNGLE}

the giraffe is by no means deficient in that sense. Still, it always sees the enemy first.

It is usual to post notices in menageries requesting that no food be given to the giraffes. This is done at our own Zoo. It is certain that the authorities do not discourage the practice without good reason, for, so long as the recipients of such gifts do not suffer, there is no objection to the public amusing itself and at the same time paying some of the food-bill. The giraffe, however, is a delicate and costly animal, and care has to be taken with its digestion. At the same time it is a very fastidious creature, feeding in captivity on the best clover hay, with an occasional onion, bunch of tares, or lump of sugar. I have been told that one, at any rate, was known to refuse an apple out of which its keeper had taken a bite. Without taking the responsibility of this reflection on the keeper's teeth, I should think it very likely that a discriminating giraffe might take exception to the taint of tobacco. At any rate, it is to be hoped that, even on Bank Holidays, visitors will respect the notice and keep their buns and nuts for less delicate stomachs, as the loss of a giraffe is a very serious item in the year's accounts.

Out on the rolling veldt, or in the cooler glades of the African forest, the giraffe is a 


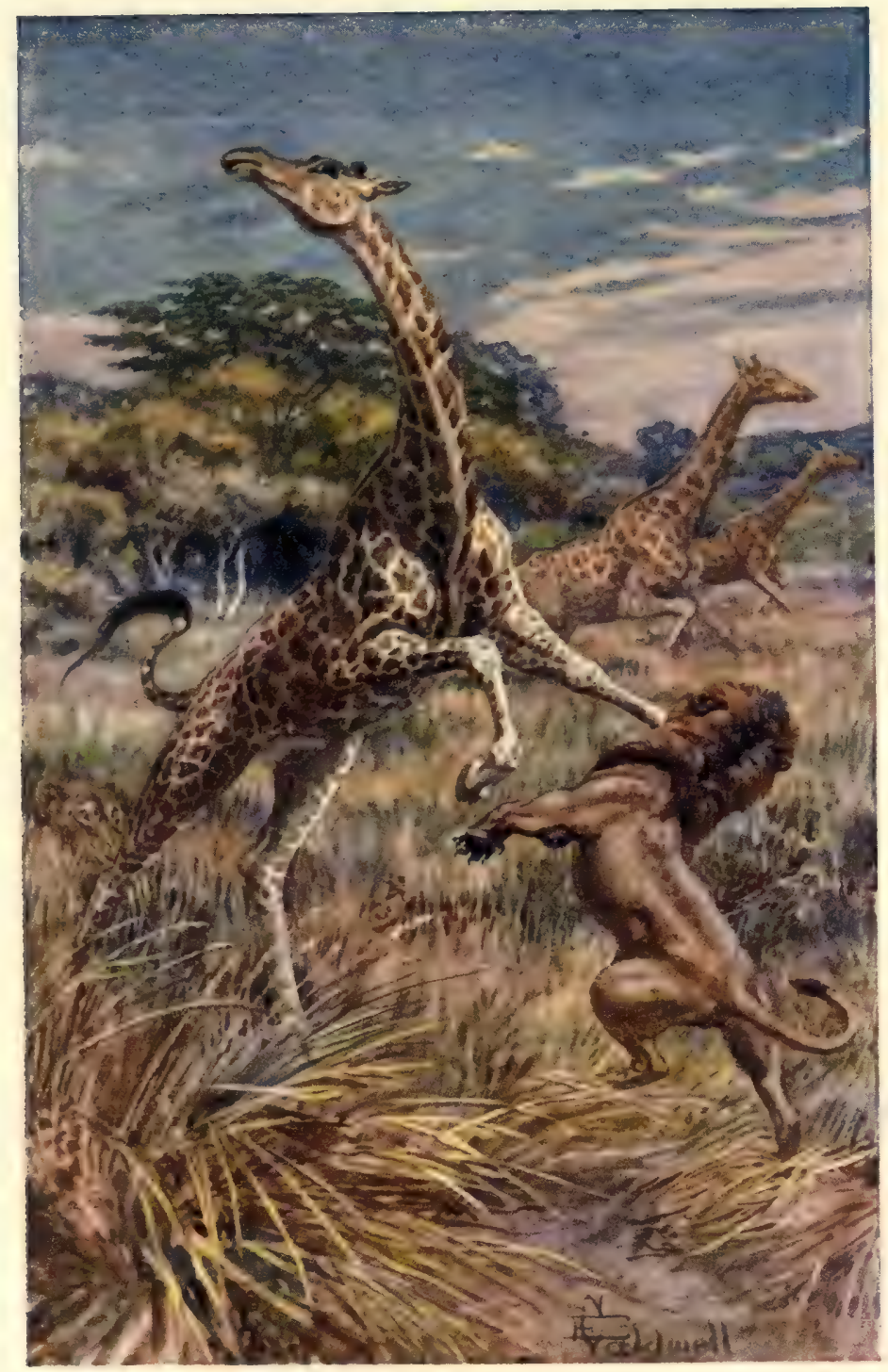

"... SO AS tO BREAK THE LION'S JAW ...." 

very different personality from the sluggish, fearless animals in the paddock at the Zoo. It travels far and wide in search of mimosa leaves, its favourite food, reaching as far as it can and stripping the branches with its long tongue, so that trees pollarded in this fashion to a kind of high-water mark are a common feature of giraffe country. The giraffe is fragile in appearance and timid by nature, yet, when suddenly attacked by a lion, it sometimes manages to kick with such terrific force, with hind or fore feet, as to break the lion's jaw. More often, no doubt, the lion that manages to get close enough for a spring must kill and eat his prey, but such retribution has been known to fall on the tyrant more than once.

When fighting among themselves, half in play, or at any rate without intent to do any very serious damage, giraffes often butt with their heads and fence with their false horns, which are occasionally damaged in the fray. The giraffe's most effective weapon is the foreleg, with which it chops downwards. John Stromboom, a well-known trader round Lake Ngami many years ago, was, Mr. Bryden tells me, nearly killed by a wounded giraffe in this way. He had ridden up to it when it suddenly reared on end and struck at him with both forelegs, missing by only a matter of inches. Had the blows got home, both he 


\section{THE WILDERNESS AND JUNGLE}

and his horse would have been done for, as the force of such strokes from an animal that weighs nearly a ton must be immense.

Unless there is urgent need for meat, these beautiful and inoffensive animals should never be shot. There is no trophy even to justify such "sport," for the so-called horns are little better than knobs under the skin, and shooting a giraffe is so devoid of risk as to have little savour for the true sportsman. During Mr. Roosevelt's African trip, a cow giraffe even showed so little fear of the party that several of them were able to get up to within fifteen feet and pelt her with sticks and stones, at which she walked slowly away. That, surely, is not the sort of animal to shoot for sport! True, this particular cow was spared, but nine other giraffes were shot by members of the party. Why?

If giraffes must be killed, as they must, no doubt, at times for meat, why not hunt them in the splendid manner of the Arab swordhunters, killing them with cold steel after they have had a good run for their lives? Readers of Sir Samuel Baker's inspiring book on the Nile Tributaries of Abyssinia will recall the prowess of the Agagir, or sword-hunters, of the Hamran tribe of Arabs. Alas, the mighty are fallen! This once great tribe has, in the course of two generations, been all but exter- 
minated in the tribal warfare of Mahdiism and in border forays with the Abyssinians, and even as far back as 1899 , when the benefits of British protection reached the Eastern Sudan, only one family of the Hamran clan had outlived the terrible era of fire and sword, and was dragging out its existence in the neighbourhood of Gedaref. It is now, however, well known that the Agar, or sword-hunter, was not the monopoly of the Hamran tribe, but an institution in most of the noble, horseriding Arab clans east of the White Nile, while to the west of that river, in Kordofan and south of Darfur, there are also mounted hunters, who use the sword less than the spade-bladed stabbing spear called kibbis. These intrepid sword-hunters, whose tactics contrast curiously with those of the cautious stalker armed with the newest pattern of rifle, use their cold steel on lion, elephant, or rhinoceros indiscriminately. They usually hunt in parties of three, one acting as decoy and galloping in front of the quarry, while the other two gallop behind. One of these then dismounts, when going full speed, and hamstrings the animal on foot, using the sword double-handed, and it is then comparatively easy to finish even an elephant off, so helpless is it after the stroke. For lions they have another stroke that cuts clean through the spine. The giraffe, on the 


\section{THE WILDERNESS AND JUNGLE}

other hand, is hamstrung from the saddle by a cut delivered forwards and downwards, sword and arm in line, a few inches above the animal's near hind hock. It is well known that in battle the Arab never loses a chance of hamstringing the enemy's horses and camels. In the mêlée he always strives to detach his adversary's bridle and to fell the horse with a cut between its ears. In fact, many of the Dervish horses captured at the Battle of Firket, in 1896 , were found to have lost their ears in Arab warfare, and this mutilation had clearly been the work of the sword-cutting at the bridle headstall, to protect which some horses wore head armour.

The truly daring and magnificent sport of the sword-hunter has without a doubt declined from various causes, among which may be reckoned the game laws promulgated of late years in the Sudan, as well as the large number of firearms, licensed or otherwise, now in use throughout that region. Yet there are men still living who, armed only with cold steel, have laid low the African elephant, and, whatever regret may be felt at seeing so huge an animal destroyed in any circumstances, much of the reproach is removed when it is conquered with such weapons. The ability to keep calm and collected in face of great danger is commonly claimed by some nations of Northern Europe and America as their birthright, but those 
know better the equality of human nature under all skies who have shared the dangers and hardships of hunting wild beasts in the company of men of such mettle as the Arab, the Sikh, or the Indian Mussulman. Among the hardest and most skilful mounted hunters in the Eastern Sudan are some of the loyal Abu Ref tribe, as well as the fanatical Kinana of Sheikh Fadl el Moula and the Beni Hussein clan. In addition to these, there are also, in the big game grounds of the south-west, the Rizeigat of Ahmed Wad Egeil, the Humr, the Habbaniya, and some Bagara clans.

The cutting power of the straight, two-edged, cross-hilted sword of these Arab hunters is amazing. In the hands of a powerful and skilled swordsman, such a weapon is capable of penetrating the hide and severing the muscle of the largest elephant, and Ahmet Wad Idris, a veteran hunter of the Beni Hussein, who formerly lived at Singa and who, I believe, accompanied Count Joseph Potocki on his expedition in the Eastern Sudan, was actually known to have cut off the hind leg of a giraffe above the hock at a single blow, a feat that might almost be deemed impossible. There was another mighty hunter of the kind, one Ramadan, son of Sheikh Abu Shetal of Roseires, who hunted the wild buffalo with hound and spear, harpooned the hippopotamus, 


\section{THE WILDERNESS AND JUNGLE}

and, without firearms of any sort, slew the lion, elephant, and every kind of dangerous game in his country. This is sport indeed, and beside it our civilised pastime of shooting wild beasts with long-range rifles makes tame reading. At the same time, it must be borne in mind that these wild Arabs are brought up to such work, that their faith makes them more indifferent to death and pain than the men of other creeds, and that, even among them, only a few picked men are equal to these feats.

Comparatively few Englishmen have taken part in these tribal hunting expeditions, but I am indebted to one of the few, a cavalry officer, for a most interesting account of a giraffe hunt, which is, however, related in these pages for the sake of a remarkable episode of peculiar interest to those who love horses. It proves beyond doubt that the animal, a high-caste Arabian and the property of the sportsman who sent me the story, first knew that it had incurred blame and then sought to redeem its character for courage, which it eventually did.

This is the story in his own words :-

"It was in the year Igoo that a small party set out from Fakki Mohammed Osman, on the River Dinder, the principal affluent of the Blue Nile, to hunt big game with spear and 
sword. In the time of those well-loved Governors of the Sudan, Baker and Gordon, both banks of the Dinder were lined with a continuous succession of villages, the teeming population of which cultivated broad acres of cotton, corn, and the oil-bearing sesame. These nations had, however, followed the arts of peace, neglecting what Bacon calls 'the most certain oracle of time,' infected with the canker of prosperity, and blind to the necessity of armed combination. As a result, the entire riverine population was wiped out within a few years, so that the acacia stretched its gaunt arms over the ashes of their villages, and the wild elephant trampled underfoot the last gruesome evidences of their downfall. As, moreover, the laws of Mahdiism precluded the use of firearms in hunting, there was a marked increase of wild animals in the Sudan between 1883 and 1898 , and it was here, in the depopulated area reclaimed by the wilderness, that the sword-hunters found their opportunity.

"On the first day out, four wart-hog boars were the reward of an early start. On the second day, the party entered the elephant country and bivouacked, with no other water available than that which was carried in skins on the backs of two camels. Next morning, leaving the camels and a spare horse in bivouac, the hunters set out, leading their horses. There were Ahmet, the veteran lightweight of the Beni Hussein tribe, with his black Galla pony, 'Shansun'; then an Arab sheikh, with his smart grey, 'Bishtena'; next, two Agagir, and myself 


\section{THE WILDERNESS AND JUNGLE}

with a favourite high-caste chestnut Arabian horse called 'Bashom' (i.e. the fox); and, lastly, two footmen carrying waterskins. We had gone an hour from camp without finding any fresh traces of elephant, so we took up the tracks of three giraffe that crossed the line at right angles. The forest consisted mainly of gum-bearing acacias, each about thirty feet high, and at every mile or two we would pass a watercourse, its lower level marked by the luxuriant verdure of large tamarind, ebony and adansonia trees; and the first rains, early in June, had carpeted the undulating slopes of hard loam with springy turf and wild flowers.

"After an hour's tracking at quickened pace, during which we passed fresh tracks of other feeding giraffe, Ahmet gave the signal by, springing into the saddle, and 'Bashom' pricked up his ears as three frightened giraffes, which, though fully five hundred yards away, had, as usual, seen the hunters before themselves being sighted, began striding towards each other and then broke away to the left at a swinging canter. The riders, however, had a good start, and the horses were soon skimming over the yielding ground as if they were on a racecourse. One cow led away lefthanded and was unsuccessfully ridden by the sheikh. The two larger animals, a light tawny cow and an unusually big bull with conspicuously black tessellated markings, bore straight on abreast. The ground now became harder and was covered with long dead grass, as well as with occasional low thorns that explained 
the pieces of leather tied over the knees and thighs of the Agagir. And now it was that 'Bashom,' having outdistanced the barb horses of the rest, had drawn within five yards of the bull's near hind leg, when a powerful backward kick from that limb gave his rider a useful hint to ride wide that he was prompt to act on. The sword was now unsheathed from its place under the near flap of the saddle, but the giraffe, after delivering other backward kicks just out of reach of the sword-blade, managed to forge ahead. It was enabled to do so by the altered nature of the ground, which was now of that heavy black mould, intersected in every direction by fissures, which the Arabs call mushkok, and which is not unlike the black cotton soil of India. This kind of going, while suited to the large feet of the camel or giraffe, is very liable to bring a horse down unless he is extended at a free gallop. For this reason 'Bashom' was unable to get abreast of the giraffe's hock, the point of which is more than four feet from the heel. So the giraffe drew ahead and vanished in the forest. The Agagir now came up from behind and unsaddled their horses, and when, in half an hour, the party was joined by the two footmen, who had followed on their tracks, man and beast drank with relish, though sparingly. The veterans now surveyed the Arabian horse and sadly gave it as their conviction that his failure to close with his first giraffe was due to timidity. He might, they admitted, be gifted with a surprising turn of speed, but he lacked 
spirit; and they even went as far as to say that his cowardice would make him not only useless, but a source of danger, if he were again allowed to accompany the Agagir.

" Now 'Bashom,' in common with most high-caste Arabians, possessed what Arabs call the 'human eye,' the type of eye, that is, with white surrounding the dark pupil. Those who know and love horses and dogs are familiar with this type of eye. It is the eye that smiles, that listens, that mourns. At this appalling insult from the Agagir, 'Bashom's' eye was as if fired with understanding. He, the comrade of Arabs from his foalhood, knew the sting of their taunt, and for a moment there was reason in his glance. Read the sequel.

"That same afternoon the hunters once more took up the tracks of the giraffes, and the camp was moved. On the advice of Ahmet, I now rode my second horse, and 'Bashom' brought up the rear with the camels and Agagir, some two hundred yards behind. The party had just crossed a valley, when suddenly a giraffe was seen stalking across the front, not two hundred yards ahead. It took the beast an appreciable time to turn, and the two horsemen were riding it before it was in its stride. But, in less time than it takes to tell, there was a third in the race, coming up from behind. In a few strides, 'Bashom' was alongside his master. In vain the Hamran Arab who rode him tried to steady him. In negotiating a watercourse, the man was deposited on the ground, and 'Bashom,' taking 
his own line, headed straight for the giraffe, brushing through the thorns as if they were bullfinches, and taking every fallen tree-trunk in his stride. A new element was now introduced into this extraordinary chase in the shape of four hartebeest, of dark chestnut colour, which, startled out of a patch of scrub by the fugitive giraffe, joined in the procession until the strong running of the riderless Arabian scattered them to right and left. Ahmet, once more to the fore, now feared that the runaway might cross him at the critical moment and made one or two futile cuts with his hide-whip in the hope of turning the animal from his course ; but 'Bashom,' with a snort of defiance, rushed headlong at the giraffe as if he meant to ride it off to the right from the near side. The terrified creature did, in fact, swerve to the right, but, in so doing, managed to deliver a knock-down blow with its near hind leg, which came home on the shoulder with such effect that poor 'Bashom' turned over on his back as if he had been shot. Yet he had achieved his object, for the giraffe's turn to the right undoubtedly sealed its fate. It was overtaken, the sword flashed from its scabbard, and a sweeping blow from the blade severed the hamstring, while a simultaneous twist to the left saved 'Blue Fire' from being crushed as the bull toppled over. As the hunters dismounted to give the coup de grâce, a sorry object trotted past the fallen foe. It was 'Bashom,' dead lame, covered with mud, and with the saddle turned round on his left flank, 


\section{THE WILDERNESS AND JUNGLE}

but he was proud in the knowledge that he had shown his mettle and retrieved his reputation.

"'Twelve years are gone, and 'Bashom' has a happy home in the green fields of Essex, enjoying the rest that he earned so well in those strenuous days. It may be that, now and again, as his 'human eye' gleams with gratitude to his benefactress, he recalls the fierce scent of the battle-smoke and the flash of the sword."

The zebra, another exclusively African type, is a wild horse in a tiger's skin, or as such, at any rate, it impresses all who see it for the first time. Time was, not long ago, when Africa produced four different kinds of zebra. But the Boers (being as fond of zebra meat as lions are) exterminated one of these known as the quagga, the last survivor dying in captivity in 1883 , so that (as in the case of the Little Nigger Boys) there are now only three. One, the mountain zebra, is also called the common zebra, though, as a matter of fact, it is very scarce, being found only in the high mountains of Cape Colony, where it is strictly preserved. Else it might have gone the way of the quagga. The two others are named after Burchell and Grévy. The last named, which has its home in Abyssinia, is also very rare, and it was said at the time that the market value of a fine pair 


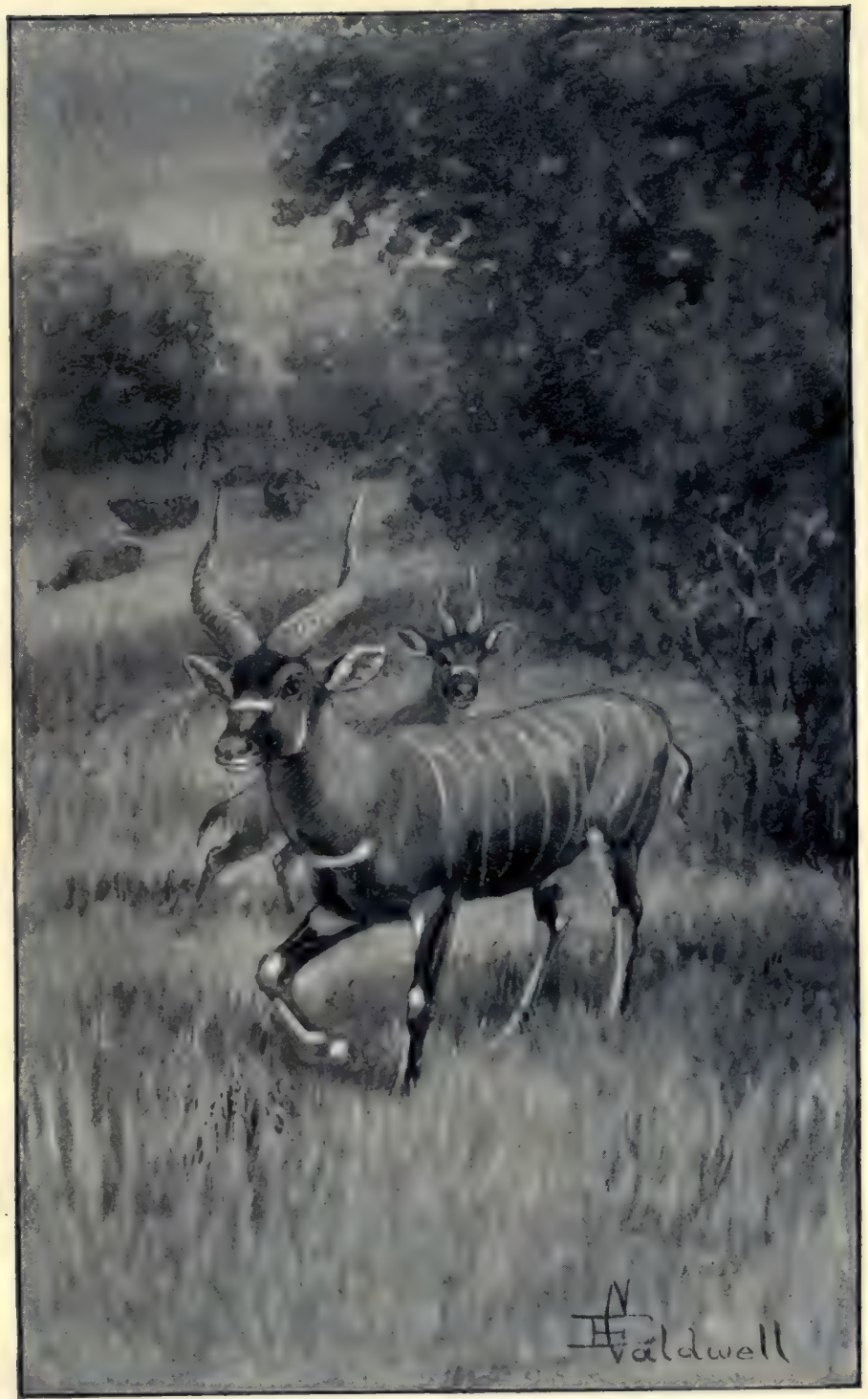

A RARE ANTELOPE.

The Bongo is the largest of the West African bushbucks. Little is known of its habits, save that the animal lives in the forest and is nocturnal. 

CREATURES OF THE WILDERNESS 205

presented to Queen Victoria by Menelik could not have been less than $£$ rooo. Of the domestication of the zebra, which has never been very successful, more is said in another chapter. I know of one that was driven in a trap by a lady living near Abergavenny, and a more famous team was that belonging to $\mathrm{Mr}$. Lionel Rothschild; but the zebra in harness is a problem that needs patience. Sportsmen shoot zebras only, as a rule, when their camp boys want meat, as the animal's flesh, though unappreciated by Europeans, is a delicacy to the negro, who is also an admirer of crocodiles' eggs and buzzards. Apart from this occasional necessity, the zebra interests the sportsman chiefly on account of its annoying habit of galloping wildly round him when he is stalking better game and thereby giving the alarm to all and sundry, spoiling many a good shot by its eccentric behaviour.

\section{ANTELOPES}

The antelopes, which carry solid horns, are regarded in the museum as furnishing a link between the goats and oxen, and are, in fact, related to both groups, a cousinship best appreciated when we look at the gnu, or wildebeest, which is much more like an ox than antelope. The variety and importance 
of Africa's antelopes have already been referred to. Asia has half a dozen of no great size, and the two which occur in America are eccentric rather than attractive; but Africa has close on a hundred different kinds, ranging in size from the great eland, which may weigh two thousand pounds, down to the tiny bluebuck and dik-dik, which may be weighed in ounces. In the great hunting days of such pioneers as Roualeyn Gordon Cumming and Cornwallis Harris, vast herds of antelopes blackened the veldt, troops of them wheeling and galloping over the emerald-green of the plains with an effect that those who know the lifelessness of those scenes nowadays find it hard to believe. They are gone now, and their haunts have passed to the Afrikander. Yet the commoner kinds are still abundant in tracts like the Kalahari, where they can always enjoy comparative immunity from man. The horns of these beautiful animals furnish most of the attractive trophies of shikar, and the corridors and staircases of more than one London club, and notably of one in St. James's Square, absolutely bristle with horns of every type, including the straight, spiral horns of the eland, the sweeping weapons of the beisa and gemsbok, the magnificent curves of the roan and sable, the V-shaped crown of the hartebeest, and many others. There is also 
much character in the faces of these antelopes, and it would be difficult to confuse the pied black and white countenance of the gemsbok, the mournful face of the hartebeest, and the fringed forehead of the addax. Naturalists were long exercised by the apparent anomaly of so magnificent an animal as the eland thriving in an all but waterless waste like the Kalahari, which even smaller kinds seemed to avoid. It was Selous who, with his usual genius for getting information out of the natives, who for the most part are either reticent or misleading, found that the Kalahari produces not only water-melons and a bulb that is full of moisture, but also a certain bush, the leaves of which form the eland's favourite food. Even the smallest antelopes, though feeble-looking little creatures, sometimes show wonderful courage and endurance; and Sir Godfrey Lagden tells me that he has known even the little steenbok and duiker draw hounds away from their young and sacrifice themselves so as to save the family; and he once saw a mountain rhebok, with one leg broken, get away on the other three, and actually escape from a pack of dogs in hot pursuit.

The most grotesque of all the antelopes are the gnus, or wildebeests. Of the two kinds, one has a black tail and the other a white. To anyone unfamiliar with their identity they 


\section{THE WILDERNESS AND JUNGLE}

suggest wild oxen out of drawing, and their habits are as strange as their appearance. Troops of them come prancing and curveting about trek waggons and caravans in a manner that would alarm anyone unaccustomed to their ways, as there is something ferocious in the aspect of their bristling faces and thick manes, while their comic appearance is enhanced by the bushy tail and slender legs. As a matter of fact, though less formidable than they appear, these animals are anything but sweet-tempered in captivity, and their keepers in menageries generally learn to treat them with distant respect.

That antelopes, as, in fact, most wild game, rely for protection on scent rather than on either eyesight or hearing is generally recognised, though the theory is accepted by the majority of sportsmen that animals living on the open plains depend on their sight more than those inhabiting jungle, where they would be warned of the enemy's approach by getting wind of him or by hearing the crackle of the undergrowth. That even creatures in the open, however, smell the enemy rather than see it is strikingly demonstrated by a very interesting episode recently communicated to The Field by Mr. Reginald Sharpe.

Mr. Sharpe was watching a herd of reedbuck, about twelve in number, in an open glade near 
CREATURES OF THE WILDERNESS 209

the Lujenda River, in Portuguese Nyasaland, when he saw a lion walking towards them up-wind without the slightest attempt at concealment. Though the lion passed within ten or twelve yards of one of the bucks, and in full view, this animal, like the rest of the herd, merely stared at the intruder, but made no attempt to get away and showed no sign of alarm. Then the lion went on his way along a dry watercourse, disappearing from view. By now, however, the wind was blowing from him to the antelopes, which immediately dashed away to safety. From this curious sequel Mr. Sharpe reasonably concludes that they did not recognise the lion as a dangerous animal until they got wind of him.

\section{BUFFALO}

The Cape buffalo, though rather smaller than the Indian "bison," is, if anything, even more dangerous when wounded, so that with sportsmen who prefer a little give and take in such encounters it is a great favourite. Unfortunately, much of the best buffalo country, which lies on the east coast round the mouth of the Zambesi, is "fly" country, and very unhealthy besides, so that sportsmen can shoot there only in the autumn. On the other hand, the drawbacks of the climate act as a more 


\section{IO THE WILDERNESS AND JUNGLE}

effectual protection of the buffalo than any game laws. Often the buffalo gives more than he gets, and, as will be related in a later chapter, more than one sportsman has been killed by these animals. An old bull buffalo is black and hairless, but the younger males are red. The ears are large and hairy, and the horns are wide and massive, with a helmet, or boss, protecting the forehead between. The largest known buffalo measured $9 \mathrm{ft}$. without the tail and stood over $4 \frac{1}{2} \mathrm{ft}$. at the shoulder. The horns measured 53 in. round the curve and nearly 48 in. from tip to tip. But such figures are quite exceptional.

Like other wild oxen, the African buffalo is fond of wallowing in water and of plastering its body with mud as protection against the bite of the tsetse-fly, which is said to derive from this source the parasite of the dreaded disease called rinderpest, which infects the tame herds and ruins the farmers, who, in consequence, clamour for the extermination of buffalo in their district. As one of the tsetse-flies also conveys the microbe of sleeping-sickness, an even graver plea has been raised for the destruction of the buffalo and other big game. Opinions on the subject differ considerably, even among those qualified to write of it. Selous regards the buffalo and tsetse-fly as inseparable. Others, on the other hand, have 
gone so far as to declare that these flies, like mosquitoes, are only bloodsuckers by preference, and that, when unable to drink blood, they readily feed on vegetable juices. For this remarkable assertion there seems to be too little evidence, but there is, at any rate, some reason for thinking that these water-haunting insects may exist on the blood of cormorants, crocodiles, and other neighbours that share their haunts, without being in any way dependent on the buffalo. If this can be demonstrated, then it is obviously futile to hope that the extermination of the buffalo would have the desired effect of freeing Africa from the tsetse-fly, and, short of such result, the total suppression of so fine an animal would be a matter for regret.

A story is told of an encounter between a Belgian sportsman in the Congo and a solitary old male buffalo, which reads less like a hunting incident than an episode from the Spanish bull-ring. It seems that the Belgian had fired at the buffalo and missed it. His native carrier chose that particular moment (not a bad one) to bolt with the other gun and all the cartridges. The bull chose the same moment to charge. Most men of ordinary temperament would have made for the nearest tree; but the brave Belgian, scorning to turn his back on the foe, preferred to catch the buffalo by the horns and 


\section{THE WILDERNESS AND JUNGLE}

pull it to the ground, where he seems to have held it till his followers ran up and put an end to it. As the animal probably weighed five or six hundredweight, those may believe the story who like. No wonder Cæsar calls the Belgians "very brave" !

\section{WILD SHEEP AND WART-HOG}

Allusion has already been made to Africa's one wild sheep. Richer in antelopes than the rest of the world, it has but this single insignificant mountain sheep, the aoudad (wrongly called "moufflon") of the Atlas Mountains. This animal, which is much more like a goat than a sheep, has long reddish hair, black incurved horns, measuring about 25 inches over the curve, and a regular bib and apron round its neck, and it stands a little over 3 feet at the shoulder.

It is one of the sportsman's disappointments. Common in almost every Zoo, from Berlin to Bronx, its quest in its native hills is like that of a needle in a haystack. I write feelingly on the subject, for I have not yet forgotten a hot summer thirteen years ago in which I clambered nearly 6000 feet above sea-level in its tracks and found no more than I might have looked for on the beach at Mogador. I am told that the high Algerian Tell is a more likely region 
to seek it in, and hope that this may be the case; but I shall not pursue it again. I should, in fact, as soon expect to come across the wild elephants that used to walk along the beach near Tangier in the time of Hanno the Carthagenian. Yet I could not have been far from the haunts of the aoudad, for a native guide pointed to a high peak, near the Castle of Gundafi, from which, he told me, a severe snowstorm had once driven a flock to take refuge in an outhouse, where, half-starved and frozen, they were presently secured by the Kaid's men and held captive. In fact, few wild animals are more easily tamed.

Of wild pigs, the most remarkable in Africa is the wart-hog, which, with its enormous flattened head, warty face, and great tusks in both jaws, is certainly the ugliest pig on earth. Young wart-hogs are less grotesque and more graceful than their parents, yet even they are not beautiful. The wart-hog stands about 30 inches at the shoulder, and the tusks would measure, in a large specimen, 25 inches.

The wart-hog is not as savage as it looks, lacking the pluck of the wild boar, though not hesitating to charge dogs, which stand a poor chance against a double array of tusks. Perhaps the trick which most disconcerts sportsmen unused to it is that of bolting out of its burrow head over heels, looking as if it were 


\section{THE WILDERNESS AND JUNGLE}

charging backwards. This is very amusing to read of, but less satisfactory when the performance is witnessed by someone standing over the burrow, who is apt to find that these gymnastics bring the wart-hog's tusks disagreeably near his own shins. 


\section{CANADA AND SOUTH \\ AMERICA}

The countries in the New World of chief interest to Englishmen seeking a career abroad are first Canada, and then British Guiana and neighbouring countries of South America. To the sportsman, on the other hand, it is Canada, and more particularly the western section of it known as British Columbia, which constitutes one of the most wonderful summer playgrounds for trout-fishing and winter playgrounds for biggame shooting in all the world. There is sport also, however, in the eastern provinces. The salmon rivers of Newfoundland, New Brunswick, and Quebec have a reputation unrivalled by even those of Scotland or Norway, and the caribou of Newfoundland, with moose and deer in New Brunswick, also attract numbers of sportsmen every autumn. Those who go for the winter shooting, and not for the fishing in July, must, no doubt, face the rigours of a Canadian winter, but they are, at any rate, free from the terrible flies which make life all but unbearable in the backwoods down to the end of July. As the salmon-fishing of the Restigouche and other famous rivers of the North Shore ends by the middle of August, it is impossible to keep clear of the black fly, which, 


\section{THE WILDERNESS AND JUNGLE}

with the midge and mosquito, is an even worse pest in Newfoundland.

British Columbia has, thanks to the inaccessible sanctuaries high up in the Rocky Mountains, become the last refuge of many of the finest North American animals, and there the grizzly bear, wapiti, and bighorn still hold out against the rifle and other resources of a greedy civilisation, their survival being encouraged by the Canadian Government, as well as by the provincial game wardens, who do all they can to punish poachers and to regulate the destruction of the wild game. The Canadian National Park at Banff, of which something is said in the concluding chapter of the book, is a model for all such establishments, and reflects the greatest credit on Canadians in general and on those responsible for its control in particular.

\section{OXEN, SHEEP AND GOATS}

The musk ox is the nearest Canadian relative of the bison, or buffalo, and the latter, existing as it does only under protection, is more appropriately referred to elsewhere. The musk ox is a native of the dreary Barren Grounds and the desolate shores of the Great Slave Lake. This wild ox of the frozen north stands $4 \frac{1}{2}$ feet at the shoulder, and is, like 
other North American types, a peculiar mixture of several families. Though it goes by the name of ox, it is almost as closely related to the sheep, or perhaps it would be still more correct to regard it, strictly, as quite distinct from either group. Its long body is covered with a thick coat of very long hair, and the horns, which average a little over 24 inches, are very solid and curve downwards in a way unusual in horned animals. It is hunted with dogs and then shot while the dogs hold it at bay, a very poor sort of sport, if such slaughter can be called sport at all.

The bighorn sheep, though still found throughout the Rocky Mountains, as far south as Mexico, is at its best in British Columbia, and has, in fact, so far as the United States are concerned, retired to all but inaccessible height in Wyoming and Montana, where its powers of climbing have so far averted the fate meted out to the buffalo of the plains. The ram stands a little over 40 inches at the shoulder, and the massive, wide-curved horns have been known to exceed 50 inches over the curve. They are often broken off at the tips, which probably occurs in fighting, though certainly not, as was formerly believed, by these animals jumping over precipices and alighting on their horns! This animal is protected in British Columbia by a close time, as 


\section{THE WILDERNESS AND JUNGLE}

well as by licences limiting the bag. Like other mountain sheep, it is always on the look out for danger, and can, as a rule, be shot only from above.

The Rocky Mountain goat is not a goat at all, but rather an antelope. As its horns never exceed 12 inches they are a wretched trophy compared, for instance, with those of the bighorn, and if sportsmen still go after the animal at all, it is on account of the well-known difficulty there is in reaching its haunts, which can be arrived at only by the most arduous clamber over terrible ground far above the timberline. Thus, whereas the bighorn is an exceedingly wary and difficult creature to stalk, the "goat," once found, offers no further difficulty or interest, being one of the most foolish wild animals in creation. It has a characteristic crouching attitude that is very peculiar, and quite unlike that of any other animal of its kind or size, and, though a wonderful climber, it lacks the quickness of movement and agility of other mountain game.

An animal of the United States that must stand alone is the pronghorn antelope, the only living animal with hollow horns that are shed annually as deer shed their antlers. These 
CREATURES OF THE WILDERNESS 219

horns measure about 17 inches. There are also peculiarities about the hair on the neck and body. If the bighorn is sought for its horns, and the "goat" for its inaccessibility, the pronghorn is shot for its flesh, which is delicious eating, even in summer, when so much other game is not worth the cooking. Unfortunately it is being fast exterminated, and the time cannot be far distant when, like the bison, it will survive only in protected parks; and even in the Yellowstone, where it is safe from the sportsman, it is being devoured by wolves. The true home of the pronghorn is on the open grassy plains from Manitoba southward to Nevada and California, and it was even found in the Colorado desert, as far from regular supplies of water as the eland of the Kalahari. It is a delicate animal, and even suffers from severe winter weather. It is also a wary creature and must be stalked with infinite patience. Even so, in the absence of cover on the plains, it must generally be shot at long range.

\section{DEER}

The deer of Canada are of great importance to the sportsman, including as they do the moose, caribou, wapiti, mule deer, and whitetail, or Virginian, deer. The greatest of all 


\section{THE WILDERNESS AND JUNGLE}

living deer is the moose, and a bull moose will stand over 6 feet at the shoulder. The record

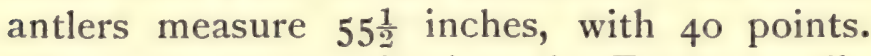
This is the same animal as the European elk, which is chiefly shot in Norway and Sweden, but which also ranges through Russia to the Caucasus. In Canada it is found chiefly in the Lower Provinces, i.e. New Brunswick, Quebec, and Nova Scotia. Besides being the largest, it is also without doubt the ugliest of deer, its hairy throat, flat and spreading antlers and huge snout giving it an ungainly and forbidding appearance, particularly if seen suddenly and unexpectedly at close quarters. In colour, the bull goes from black to grey, and the antlers are shed in the depth of winter. The moose feeds chiefly on young shoots of the birch and spruce and, in summer time, on lily pads, wallowing in the cool brooks and tearing these up wholesale, so intent on gathering its salad as to be oblivious of approaching canoes. As, however, the summer close time is strictly enforced, it runs, or should run, no risk of being shot with anything worse than a camera. I regret to say that it is precisely in the summer months, when the game wardens are off duty, that the poachers are most active, particularly in Madawaska County. The authorities do all they can to prevent such breach of the law, and not long ago a 
man was fined $£ 40$ for killing a cow and a calf. Yet the moose is holding its own in some districts, and even increasing in a few, in spite of the fact that the number shot lawfully by licence-holders in rgro amounted in New Brunswick alone to no fewer than 2052.

The usual way of shooting moose is by calling the bull within range of the rifle. This can be done only in early autumn, and the services of a professional caller, who uses a birchbark trumpet for the purpose, must be engaged. It is not, in any case, a very highclass amusement, and indeed, Colonel S. J. Lea, c. B., to whom I am indebted for the following reminiscence of moose-calling, regards it frankly as "about the most poaching form of sport" he ever took part in. He describes it thus :-

"It was at the first full moon after September I5, some years ago, that I found myself with two Micmac Indians in a birchbark wigwam near a lake in the backwoods, not far from Windsor (N.S.). There were duck on the lake, snipe in the marshes, and ruffed grouse in the woods, yet not a shot was fired at any of these, as one of my guides had come across signs of moose. Our camp was pitched in the timber on the lake shore, and after dinner the guide, whose name was Andrew, shaped a conical horn out of birchbark, which 


\section{THE WILDERNESS AND JUNGLE}

he then put to his lips, and, lo! the dullthroated roar of a bull moose echoed through the still forest, rising and falling in wonderful imitation of the creature's challenge. We listened intently, but in vain, for no answering roar came in response. Then, after waiting for a quarter of an hour, the call was repeated, but again without result, so we turned in and lay down on the fragrant beds piled high with tips of hemlock.

"Next evening Andrew called again, and now indeed there came from afar the answering call. Then, after another wait, which seemed like an hour but could only have been a matter of minutes, he called once more, and again the answer reached us, this time from much closer at hand. The next sound we heard was that of the moose thrashing his way with his antlers as he came through the undergrowth. Fortunately the wind was in the right quarter, and still he came in our direction, when suddenly, perhaps a hundred yards from where we waited, we heard him no more, and concluded that he must have stopped. And now Andrew gave just one low grunt on his trumpet, and I slipped back the catch of the rifle, staring anxiously into the gloom, where the moonlight threw such fantastic shadows that it was easy to mistake the boughs of trees for spreading antlers. Suddenly, John, my other Indian, touched my arm and pointed towards the darkness. He, of course, could see the moose, but my eyes were not those of a Micmac, and it took me a moment longer to make out the 
great Roman nose and broad antlers of a large moose standing head on. In that dim light I dared not risk a shot at the animal in that position, but in a few minutes it turned and gave me the chance of a broadside. I fired, and the moose fell to the shot, but, although it had a very fine head, and although my licence allowed me to shoot four moose, this one was the first and last I cared to kill by such means!"

In spite of its great strength and stature, the moose is said to leave a district when the smaller white-tailed deer comes into it, while the caribou, in its turn, retreats before the moose. The latter statement bears the stamp of probability, but it is not easy to believe that an animal of such fighting weight as a moose would give way before another much smaller member of the same family. A deer would not scale more than one-eighth the weight of a moose. Yet we are asked to believe the lighter animal capable of driving the other before it. Facts, no doubt, are facts, and it seems established that the same district is not suited to both kinds. Yet there may be some other explanation than that commonly accepted. Is it, for instance, not possible that there are periodical changes in the vegetation, or other conditions, of a district 
which may simultaneously make it suitable to the needs of the smaller animal and no longer habitable for the larger?

The moose is known in Europe as the "elk," but the "elk," so-called, of America is a very different animal, more correctly known as the wapiti, a magnificent deer, and second in size only to the moose itself. A big stag may stand $5 \frac{1}{2} \mathrm{ft}$. at the shoulder, and the record antler is over 60 in., twenty-pointers having been known. The wapiti is also found in the Caucasus and in Manchuria. It used to be common on the east side of America, but has long been exterminated there, and now has its last refuge in the Rocky Mountains, both on the Canadian side and in Colorado and Montana. The finest are found in Vancouver Island and in the hills on the mainland opposite. In other days, when these animals were more plentiful and less suspicious of man, they could be ridden down and shot with revolvers, much as Mr. Winans occasionally rides down his park deer. Nowadays, however, the wapiti must be stalked and shot at comparatively long range. The herd rests during the greater part of the day, but also feeds at intervals, and the easiest time to shoot the stags is when they are challenging each 
other to battle royal. The wapiti does not, like some other deer, hide away in the gloomy depths of the forest, but, where not disturbed, prefers the edge of the timber, with open clearings to feed in. It grazes and browses, eating all manner of grasses, as well as leaves and twigs.

The case of a sportsman (Sir Henry SetonKarr) coming right on a sleeping buffalo has been quoted, and he also draws my attention not only to the extraordinary watchfulness of deer, but also to the curious habit of wapiti and others, when in herds, leaving the sentinel duty to the females. The cow wapiti is aware of danger in an instant. When uncertain of its nature or direction, she gives a warning bark, but the least scent, even if only picked up by a straggler, sends the whole herd away at top speed, as if moved by a single impulse, and always in the direction of safety. Moreover, deer are usually able and willing to help one another. By way of illustrating this, Sir Henry recalls the following experience: "I was once stalking a good stag on a far-away island of Norway. I had watched it feed into a deep hollow. During the stalk, a smaller stag, some distance away, got wind of me. Now, instead of immediately bolting, as it might reasonably have been expected to, the smaller animal did his best to warn the other 


\section{THE WILDERNESS AND JUNGLE}

of his danger by trotting up to him and trying to attract his attention. Unfortunately for the big stag (but fortunately for myself), the great depth of the valley into which his big friend had fed thwarted his gallant attempt."

The caribou of Canada (also found in some of the northern States) is the same animal as the European reindeer, though Americans insist on distinguishing two different kinds, the Barren Ground and the Woodland caribou, the latter being much larger and more southern in its range. A full-grown stag may stand $4 \frac{1}{2} \mathrm{ft}$. at the shoulder, and in Newfoundland even taller examples have been shot. The longest recorded antler is 62 in. As in the reindeer, both sexes carry antlers, and both, of course, cast them each season.

Caribou feed on moss and lichens, also on cranberries and other wild fruits. The Woodland caribou keeps in the same district as a rule, though restless at some seasons of the year; but the Barren Ground kind band together in immense herds and perform long migrations east and west at regular intervals, a habit taken advantage of by those who shoot them. This animal has, as already mentioned, splay feet, which enable it to run at great pace over 
soft ground or snow, without crashing through the surface crust in the manner that so often proves the undoing of a moose when pursued by hunters. It is, in consequence, when only slightly wounded, a difficult animal to follow up.

The two other deer of North America are the mule deer, also called black-tailed deer, and the Virginian, or white-tailed, deer. The mule deer is found only on the western side, and the true black-tailed deer is restricted to the Pacific Slope. A full-grown stag stands 40 in. at the shoulder, and the antlers may measure 34 in. They have two V-shaped forks, while those of the white-tailed deer are distinguished by three upright spikes. The record antler of the white-tail is over $27 \mathrm{in.}$ and carries fifty-two points. The mule deer lives in the ravines of the Rocky Mountains, and particularly in the broken ground of the foothills. It is found as far south as California, where, however, it gives way to the true black-tail. The Virginian deer skulks in the dense forests of the east and south. I have watched it of an evening along the banks of Canadian rivers in summer-time, and I once saw one through my glasses busy licking an 
228 THE WILDERNESS AND JUNGLE old stranded pork barrel for the sake of the salt.

\section{BEARS}

The handsomest bear in Canada is the polar bear of the northern ice, a region which lies somewhat north of the latitude of this book. The grandest wild beast in the Rocky Mountains is the grizzly bear, also known as the silver-tip grizzly, perhaps the fiercest and most terrible of all bears. Like the lion and tiger, the grizzly will always make itself scarce if not molested, but when wounded or at bay it attacks with sudden and tremendous savagery. A large grizzly measures over $8 \mathrm{ft}$. from snout to tail, and weighs over rooo lbs.

The food of the grizzly bear is very varied, including grubs and insects, roots, berries, and wild fruits, as well as cattle and carrion, the last chiefly such putrid salmon as it can find on the river banks. It is a great cattle-killer, and in consequence of this habit a price of ten or fifteen dollars is put on its head in many States. The grizzly is still not uncommon in Wyoming and Colorado, but is more often shot in British Columbia. Its fur is at its best in May when the animal comes out of its cache, or winter quarters.

Dr. T. G. Longstaff sends me particulars of an 
exciting encounter he had with three grizzlies which, to my mind, illustrates their courage, ferocity and, above all, extraordinary vitality more than any other yarn I ever remember hearing.

Early in the month of September, I9Io, he was on the summit of the divide of Purcell Range, Selkirk Mountains, British Columbia, looking for a pass over which to get his packtrain.

While prospecting, he suddenly saw three grizzly bears emerging from the tree-line immediately beneath him, and the party proved to be an old female with a couple of lusty twoyear-olds. It is said by the Indians that grizzlies do not leave their cubs before two years. Their natural history cannot, however, be implicitly relied on, as they also declare that the grizzly does not feed on porcupines, whereas Dr. Longstaff subsequently found that the face of one of the cubs was absolutely studded with the quills of that animal.

When first seen, the trio of bears was far below him and to his left, and they were coming uphill at a good pace.

$\mathrm{He}$ at once ran down, with his 355 Mannlicher-Schönauer rifle, but took too direct a course in his hurry to get at the bears and, when only two hundred yards from them, found himself on open ground and in full 


\section{THE WILDERNESS AND JUNGLE}

view of them. By this time, too, he was at about the same level as they, and detection seemed certain. However, he threw himself prone and tried to crawl to a position directly above them. They had in the mean while either seen, heard, or winded him, for they bunched together and looked straight in his direction.

As there was no cover, he opened fire. The first shot broke one of the female's forelegs, and she rolled over and over downhill and lay with her legs in the air. Next moment, however, she was up again, and rushed uphill to the cubs, roaring furiously. Another shot, far back in the ribs behind the shoulder, rolled her over again, and this time she went downhill quite fifty yards, until her further progress was arrested by a little patch of brush. Thinking that she was dead, Dr. Longstaff now turned his attention to one of the cubs and rolled that over as well. Then, to his amazement, the old bear was up once more, racing uphill and roaring more terribly than he ever heard a tiger in like circumstances. He owns to having been rather frightened of this seemingly immortal bear, but managed to hold his fire till she was within a hundred or a hundred and fifty yards of where he lay. She seemed a little uncertain of his exact whereabouts and stood erect, swinging her sound foreleg and in 
a splendid rage. The next shot finished her, and she rolled far downhill, not to rise again. The wounded cub was meanwhile making the echoes ring, and another shot finished that as well.

But all was not over, for the other cub now came charging uphill, roaring with anger, and not even stopped by a shot through one of its forelegs, though making an even more terrific noise, not of pain (Dr. Longstaff has had too varied an experience of big game to make any mistake on this point) but of rage, and evidently meaning business if it could get at him. This time he waited until it was topping a rise only just below him, and killed it with a shot through the head.

The episode impressed him with the ferocity displayed by the cubs. In the old bear, who may have had similar encounters before, it was hardly surprising, but in the cubs it was certainly unexpected. As he remarks, the bears were not in the least afraid of him, but he was undeniably afraid of them. An unarmed friend, who was standing on a point far above the scene of the conflict, saw the bears and mistook them at that distance for porcupines. He did not see Dr. Longstaff, but heard the shots and wondered why he was wasting his ammunition on porcupines! Then, though they were so far away as to look the size of porcupines, he 
232 THE WILDERNESS AND JUNGLE

heard their roaring, and marvelled that the sound could carry that distance, but no longer felt any surprise at the shooting.

Even larger than the grizzly is the immense brown bear of Alaska and Kadiak Island, with shaggy brown fur and large thick claws. Specimens have been shot in prime condition weighing $1600 \mathrm{lbs}$. This bear feeds on grass and also on salmon, either putrid or caught alive.

The black bear, which occurs throughout Canada and as far south as Mexico, is a much smaller animal, weighing at its best no more than a third of the brown kind. It keeps out of the way of human beings as much as possible, though I have seen the recent marks of its claws where it stood up to sharpen them on the wall of a wooden shanty in constant occupation by sportsmen.

\section{WOLVES}

Canada has two wolves, the great grey wolf and the smaller coyote of the prairies.

The so-called black and white wolves are merely southern and northern varieties of the grey kind, the timber wolf of the backwoods, which ranges from the Great Slave Lake, in the far north, down to the warmer climate of Texas and Florida.

The grey wolf stands over 30 inches at the 


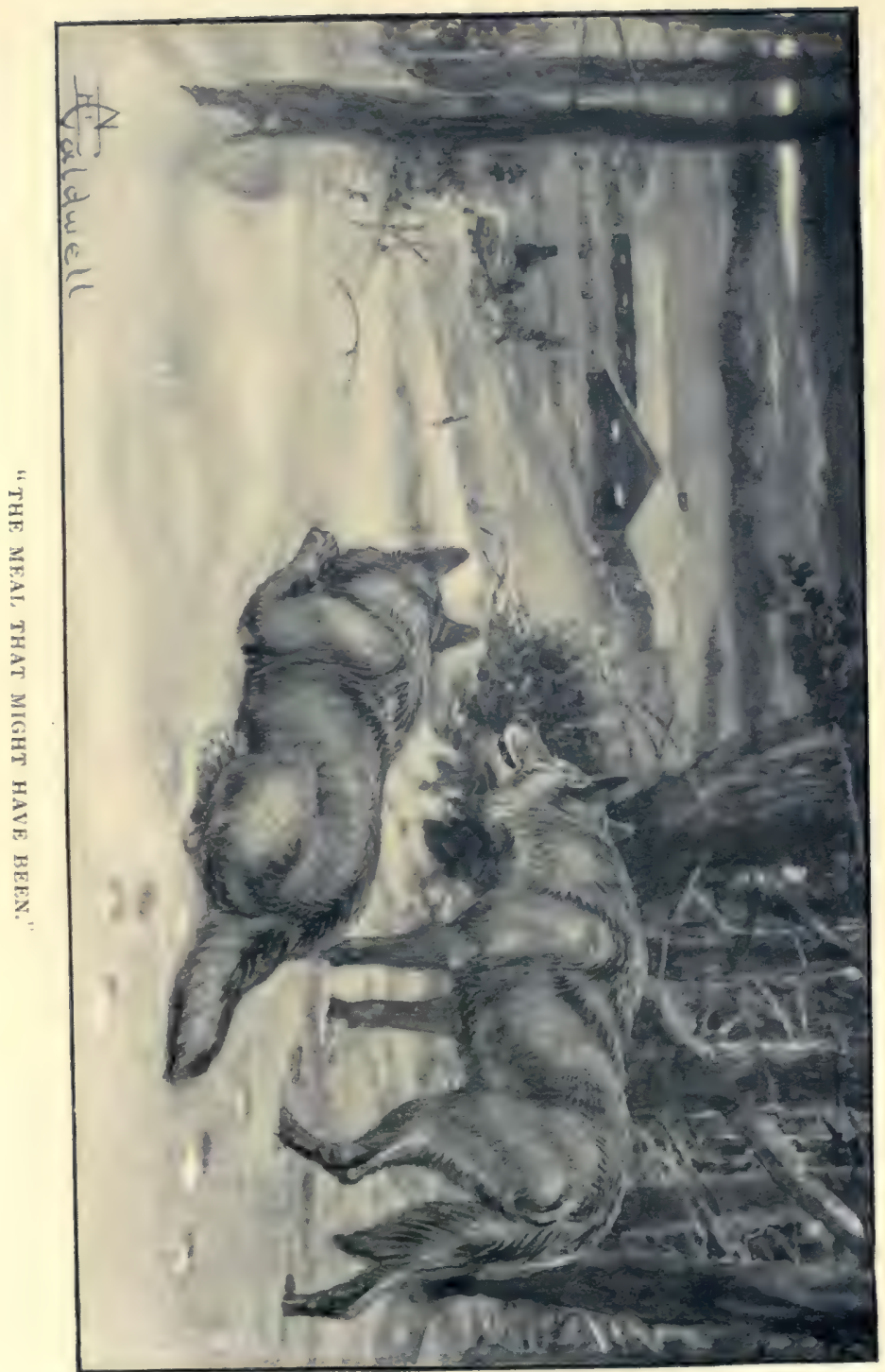



shoulder and is still as savage by nature as in the early days when it terrorised the settlers in the Far West, though it is no longer so dreaded by men armed with modern rifles. Nevertheless, it is still a source of continual loss to the farmers, and its numbers seem to increase in spite of the reward, varying from two dollars to ten, paid for its destruction in many of the States. Though always cowardly when there is a chance of escape, it is a terrible adversary when brought to bay, and even the staunchest dogs may hesitate to venture within reach of its powerful jaws.

There is in some quarters a regrettable tendency to depict the wild beasts as invariably friendly to man unless he provokes them, and to make light of the dangers he runs from them under peculiar circumstances (such as famine or anxiety for their young), which may make them abnormally aggressive. One popular naturalist, who lectured in England last spring, actually went so far as to say that the timber wolf of Canada never attacks man, a statement which it is difficult to reconcile with the fact of these animals having not only attacked but also devoured two mail-runners the year before! The wolf in winter rarely loses an opportunity, though generally it has to watch the meal that might have been.

The coyote (the word is pronounced as three 


\section{THE WILDERNESS AND JUNGLE}

syllables, with the accent on the second) is a smaller animal and even more cowardly. A whole pack would be put to flight by one man, though these animals are endowed with remarkable cunning and even know the safety of a man when he is unarmed. And the coyote appears to have no fear of passing trains, for I remember looking out of the window of a Canadian Pacific express coming east across the prairie and seeing a coyote creeping up to a stork. I doubt whether the wolf ever got near its prey in such open country, but what most struck me at the time was its absolute disregard of the train, which must have passed within two hundred yards of it.

* * * * * * *

\section{SOUTH AMERICA}

With the dense forests of Brazil, the Argentine pampas, the foothills and summits of the Andes, the banks of the longest river in the world, and many other widely different types of country, ranging from the shores of the sweltering. Caribbean to the frozen desolation of Patagonia and the Falkland Islands, South America might be expected to harbour great variety of big game. In point of fact, however, there are not more than half a dozen 
indigenous wild animals to attract the sportsman, and it is doubtful whether one of these would of itself constitute an attraction to anyone not visiting the continent with some purpose other than sport.

\section{PUMA AND JAGUAR}

These two great cats, respectively known to Americans as the "tiger" and "lion," are also found in North America, but are more characteristic of the southern continent, where they extend to the southern limit of Patagonia. As regards the United States, the jaguar is still found in southern Texas and the puma as far north as Wyoming and Montana, as well as in Florida, Colorado, Texas, and California.

The puma, also called cougar, may measure over 5 feet in length, without the tail, which is another 3 feet, but this would be an uncommonly large specimen. The largest come from Colorado, and in that State also pumas seem to be more plentiful than elsewhere.

The puma is hunted with dogs, which tree it, when it may be shot, or even knifed, without much risk to the sportsman, though a wounded puma may at times turn nasty and do considerable damage before it is despatched. It was said at one time that the puma was a kind-hearted beast, reluctant to attack a man. 


\section{THE WILDERNESS AND JUNGLE}

This may possibly have been the case before it knew the human race as well as it does now. Like the jaguar of the pioneer days, it may have been, as the Spaniards called it, amigo del Cristiano, but these friendly relations have long since changed for the worse. It was also said to weep when wounded. If it wept, it was probably because it was hurt, but certainly not, as old writers used to tell us, from grief at man's unkindness.

As, however, it is as a rule a gentle creature in menageries, it may be that, unless ill-treated, it would never dream of attacking man. A puma may even make an affectionate pet, and I remember a case of one, the property of an Oxford undergraduate, getting loose one afternoon, when its owner was playing football, and costing him $£ 5$ by way of compensation, after which he reluctantly sent it to the Zoo. It is perhaps the best climber of all the big cats and a fine swimmer into the bargain.

The jaguar, a larger and much fiercer animal, measuring 9 feet with the tail, bears strong resemblance to the Old World leopards, though the spots are arranged in a different pattern and the body colour is darker. There are also black jaguars, but these are even more shy than the commoner variety and are not so often bagged.

The food of the jaguar consists of capybaras (the largest living rodent), tapirs, and other 


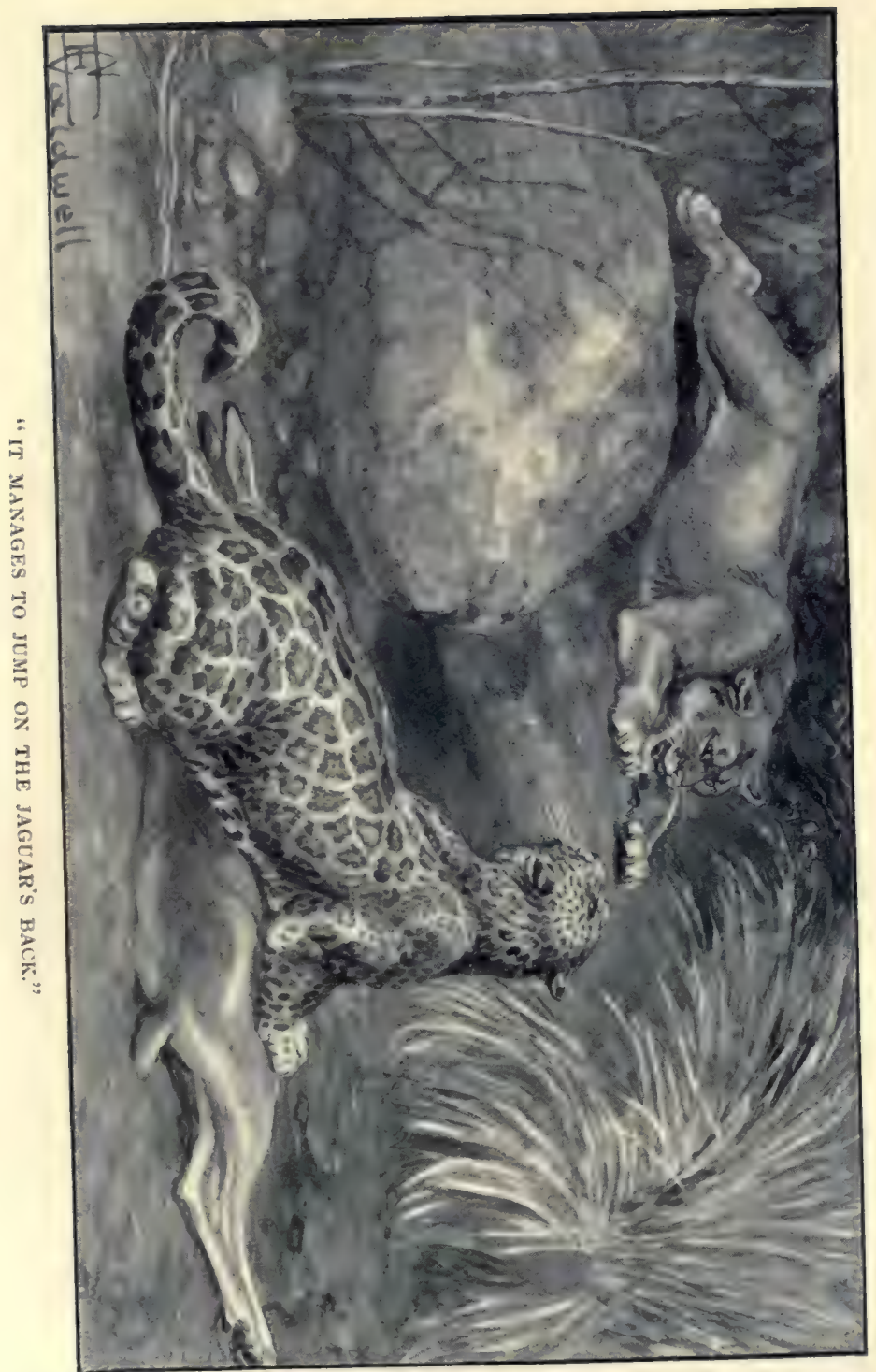





\section{CREATURES OF THE WILDERNESS 237}

animals, and when such food is scarce it catches fish in shallow pools. Unlike the puma, it sometimes turns man-eater. There is an extraordinary and unexplained feud between the two, and what is even more remarkable than their having any cause of quarrel is the fact that the puma, which is the lighter and seemingly more gentle animal, should invariably be not only the aggressor, but also the victor. It manages to jump on the jaguar's back and to maul it terribly even where the end is not fatal.

\section{BEARS}

South America has two bears, the spectacled kind and another, also found in the Andes, which seems to be closely related, but has not the "spectacle" markings. These, which give the animal its name, consist of white curves going half way round the eyes, and there are also white bands on the side of the face.

\section{DEER}

There are also at any rate two deer. The chief of these is the marsh deer, which lives on the soft ground along the banks of the great rivers of Brazil, a large animal standing about 4 feet at the shoulder. The record antlers are 25 inches. The most noticeable feature of this deer is the wide, spreading 


\section{THE WILDERNESS AND JUNGLE}

feet, which enable it to get over the marshy ground. Its face is also conspicuously long. The other deer of the Andes is the little guemal, a miniature deer, standing no more than $3^{8}$ or 40 inches at the shoulder, with antlers of less than 12 inches. It is a good swimmer, and the bucks fight desperately. An animal of this size is not of much account to sportsmen who have known better, and is included under the head of big game only because the standards of shikar in South America are modest.

\section{HUANACO}

The huanaco, or guanaco, is one of South America's four equivalents of the Old World camels, the others being the llama, vicuña, and alpaca. The huanaco, which has reddish woolly hair, stands about 4 feet at the shoulder. It may be stalked and shot, but the most exciting method of hunting it is that of the gauchos, who ride it down and then fling their boleadores (metal balls on long thongs of raw hide), so as to hobble it and bring it to the ground.

\section{THE CONDOR}

In concluding this very brief survey of South American game, passing mention should perhaps be made of the most conspicuous bird of the Andes, the condor, grandest of all vul- 
tures, with wings that, at full stretch, may spread 9 feet from tip to tip.

For all its fierce appearance, the condor is by preference a carrion-eater, though it now and again attacks a fawn or young huanaco. It seems to find its meals entirely by sight, and indeed, as Darwin suggested when much moved by the sight of these splendid birds soaring over the mountains, it probably spies the puma killing its victim looking down from some tremendous altitude at which it would itself be quite invisible to those on earth.

In view of the prominence given in the foregoing pages to so much of the Wilderness as lies under the British flag, the omission of Australia and New Zealand may seem invidious. If, however, we except the deerstalking in the latter country (and bear in mind that the deer are not indigenous, but imported from Europe), we shall find that there is nothing to attract the hunter of big game to the antipodes. The so-called sport of shooting wallabies and kangaroos, in which I took part many years ago, is not much more exciting than rabbit shooting in the fern brakes at home, though hunting these marsupials, of which I had no experience, doubtless gives exhilarating gallops across breakneck country, even if the canons 


\section{THE WILDERNESS AND JUNGLE}

of Australian packs would hardly have satisfied Beckford or Meynell. To the studious naturalist, whom the zest of the chase leaves cold, these pouched Australian animals, survivals from the earliest ages, may be infinitely more attractive than the buffalo or lion, but in a book devoted in great measure to tales of adventure they must necessarily be ignored, since their pursuit entails no more danger than that of the sheep on a farm. An old kangaroo may be formidable at bay, but no one armed with a modern rifle would need to run the risk of finding it in that position. 
THE VENGEANCE OF THE WILD

Q 



\section{III}

\section{THE VENGEANCE OF THE WILD}

IT is no reflection on the courage of sportsmen to-day to admit that modern conditions make for safety. This is not the fault of those who go big game hunting. They take things as they find them, and it would be sheer madness to decline the latest rifle and ammunition devised by the ingenuity of the makers, and to trust to the obsolete weapons on which the hunters of other days had to rely. One might as well hunt lions with the spear used by the Nandi warriors, who roused the admiration of $\mathrm{Mr}$. Roosevelt by their prowess against the king of beasts, or with the two-handed swords of the Agagir described on an earlier page. Even so, men of the Stone Age slew the shaggy aurochs with bow and arrow. Such sport means very close quarters, and it is said that one of the old elephant hunters won a wager by stalking a tusker up-wind and getting close enough to paint his initials on the animal's flank before shooting it. Such a performance is unnecessarily dramatic, but 


\section{THE WILDERNESS AND JUNGLE}

it nevertheless called for remarkable nerve and great knowledge of woodcraft.

The woodcraft is discounted in these days, when, what with long-range rifles and powerful telescopes, big game shooting suggests the conditions of a naval duel, with the difference that, in the majority of cases, the enemy does not return your fire.

Fortunately there is still a considerable element of risk. Otherwise, the shooting of big game would be less a sport than an exact science, and as such would lose much of its charm, for, as Lindsay Gordon wrote :

"No game was ever yet worth a rap

For an Englishman to play, Into which no danger, no mishap,

Could possibly find a way."

The Australian poet's verse may not rank very high, but the sentiment is the right one anyway. When arm-chair critics of sport quote pigeon-shooting they give us a hard nut to crack, but so long as men like pig-sticking and go on foot after tigers there is not much wrong with either sport or sportsmen. That the chances of disaster were greater in the days of more primitive firearms than those in use to-day cannot, of course, be denied. Even forty years ago Selous had to get so close for the shot that he was knocked down by an elephant and 
tossed by a buffalo. Accidents of this sort, and worse, still befall sportsmen, but with the difference that, whereas with the old weapons it was, as often as not, experienced sportsmen who suffered, disaster is nowadays generally the penalty of ignorance or carelessness. Yet not the most cautious can invariably reckon on immunity, for even modern rifles sometimes misfire, or the ejector sticks, and native gunbearers have not lost their habit of bolting with the spare rifle at the critical moment. In some cases, indeed, the indifferent shooting of their employer holds out no inducement to face the danger of a sudden charge in his company, and a convenient tree offers the greater chance of safety. Then, again, there is always the uncertain quantity of a wild animal's cunning, which at times will baffle the most experienced hunter. On the whole, however, the cause of accident under modern conditions is that the sportsman is either using a small-bore rifle, which calls for more accurate shooting than he is capable of, or goes after a wounded animal in high grass without sufficient precaution against those arts of ambuscade of which the buffalo and some other creatures of the wilderness are masters. Other heavy game will charge suddenly and blindly, not necessarily with the object of doing mischief, but with none the 


\section{THE WILDERNESS AND JUNGLE}

less disastrous results. Even antelopes at bay are capable of inflicting fatal wounds with their horns.

The death-roll is a long one, yet the escapes have been more numerous than the disasters and certainly more wonderful. One or two of these have already been told in these pages, and it would be easy to compile an imposing list of men, who seem to have been born under a lucky star, being snatched from the jaws of death at the eleventh hour. Moffatt, the missionary, was first nearly killed by a lion and then trod on a cobra. Andersson, a mighty South African hunter in his day, was severely injured and all but killed by a black rhinoceros. Another equally famous old-time sportsman, William Cotton Oswell, had the rare and unenviable distinction of being tossed first by a black and then by a white rhinoceros. Mr. F. C. Selous, who, as I write these lines, is still hunting in the wilds of Africa, was, at a time when even I was a schoolboy, nearly crushed by an elephant, which knocked him off his horse and knelt over him, vainly trying to drive its tusks through his body; and he had another equally narrow escape from a Cape buffalo. Livingstone, seized by a lion, did not lose consciousness but waited for the end, and so numbed were his faculties by the horror of the situation that what he chiefly 
remembered afterwards was a sensation of acute curiosity as to what might be going to happen next!

Reference has been made to the fact of modern rifles precluding the necessity of coming to close grips with dangerous game. As a matter of fact, the unexpected is always happening. Big game hunting is full of unrehearsed effects, and thus it is that, in spite of all the resources of the gunmakers, lions and tigers still get their own back. Yet some of the cordite rifles now in use do amazing work at long range, and in the right hands (this condition is commonly overlooked, but it is of first importance in determining the result) they are safe to stop even the most desperate charges at the last moment. Mr. Roosevelt, using one of Holland's small-bore cordite rifles, killed charging buffalo and rhinoceros with a single shot; and, with one bullet from a still smaller weapon, the Maharaja of Kooch Behar killed a bull bison at eighty yards, an extraordinary performance when one remembers the thickness of the animal's hide. These modern rifles and bullets make the old tales of rhinoceros hide being able to withstand shooting at even short range look very foolish.

I have already suggested that the fact of their wisely running less risk by using modern weapons than their predecessors did with the 
248 THE WILDERNESS AND JUNGLE

old guns of their generation does not mean that sportsmen are necessarily less courageous to-day. They merely play the game as it should be played. No one goes deliberately into the jungle to be killed, and it would be amazing stupidity to behave quixotically towards tigers, and to give them a better chance of victory by a voluntary handicap of inferior firearms. Yet even savages recognise the change in the odds when their cheap firearms are substituted for the bow or spear. The Abyssinians have long had a regular tariff by which the bravery of their warriors is assessed by the wild animals each has killed. Killing a rhinoceros was formerly regarded by them as equivalent to killing twenty men in battle, but to-day it counts as equal only to five, and a leopard, which then did duty for five, now represents only one.

As has been shown in an earlier chapter, some methods of shooting big game are more dangerous than others, and the most familiar gradation of safety is illustrated in tiger shooting on foot, from a machan, or from the howdah. At the same time, wild beasts vary so much in strength and cunning that not always the safest methods can be relied on to avert danger. Lions occasionally charge right through the seemingly secure thorn zareebas behind which sportsmen shelter themselves, 
and tigers have been known to reach up on their hind legs and pull both sportsman and shikari out of a machan that was thought to be well beyond their reach. Very hardy sportsmen, who go after tigers on foot, sometimes sneer at the machan as a cotton-wool fashion of bagging these dangerous brutes without the least element of risk, but a case that happened some years ago will show that their contempt is not always deserved.

This tragedy was brought to my notice by Colonel Murray, D.s.o. "The wounded tiger was tracked into a dense piece of jungle, and the shooters were placed in trees at one edge, while the beaters were moving round the other side. The tiger evidently saw where one of the shooters was placed, and, before the beat began, sprang up and dragged down first the native gunbearer and then the officer himself, who was so badly clawed before assistance could be rendered that he died the same night." Mr. Clement Le Breton, к.c., also gave me some particulars of a similar case of bloodpoisoning from the bite of a tiger that caused the death of his brother, sometime PostmasterGeneral of Rajputana. Here was no question of inexperience, as he had encountered probably fifty tigers in the course of his Indian career. That is just what so often happens. Many accidents, it is true, are caused by ignorance of 


\section{THE WILDERNESS AND JUNGLE}

how the game should be played, and it is a game with very strict rules, any breach of which may cost the player his life. Often, on the other hand, an experienced big game hunter suffers like the veriest beginner. And so it was with $\mathrm{Mr}$. Le Breton. $\mathrm{He}$ hit a tiger twice before the brute charged, and when he turned to take his other gun from the native shikari, the man had bolted out of reach. Without a moment's hesitation, Mr. Le Breton made for the nearest tree, and was just hauling himself out of reach when the tiger clawed his leg. It made another attempt to reach him, and now it managed to scratch his foot. By this time he was too high up for it, and it gave up. Unfortunately, blood - poisoning set in, and he died soon after. The wounds inflicted by such unclean feeders as lions and tigers, which eat putrid carrion, are very poisonous, and unless antiseptic treatment is administered at once, they often prove fatal. It is the lodging of putrid food in the grooved claws that so often renders even a slight scratch ultimately fatal. Major Sandbach, R.A., died from the same cause after a terrible experience with a lioness in Somaliland. The brute had previously bitten a native, who died the same night. In this encounter also, the Major's shikari had fled with the second gun, and the lioness was on him at once. He thrust 
the butt of his rifle into her jaws, but she crunched it like matchwood. Then she seized his right hand and worried it so terribly that, by way of making her let go, he gave her his left. The lioness was then shot, and his men got him alive back to Aden, but, though he underwent an operation without further delay, the poison had got into his system and he died within a month.

The lion is probably the most dangerous animal in Africa. At any rate, it has been responsible for more accidents, fatal or otherwise, to sportsmen than any other, and if South Africa has of late years played a minor part in the history of these tragedies, it is only because, during the past quarter of a century, Englishmen have shot ten lions in British East Africa and Somaliland to one bagged in the country south of the Zambesi. The lion, unless a confirmed man-eater, usually kills his victim and leaves him to the jackals. Maneaters, however, have never been so common as among tigers in India, though Mr. Teale was killed and eaten by a lion in Mashonaland about twenty years ago, and the terrible doings of the Tsavo lions, which devoured both coolies and white men, have already been referred to. The list of Europeans killed by lions makes gloomy reading and is too long to quote at length. Man-eaters commonly attack without 


\section{THE WILDERNESS AND JUNGLE}

provocation, and a transport rider named Horn was attacked by one in North-West Rhodesia. The Indian lions of Kathiawar have claimed few victims because they are rarely molested, but Major Carnegy was killed by one of them during a shoot organised for the Governor of Bombay.

There have been some extraordinary escapes from lions. In some of these cases the lion gave its victim one bite and then dropped him. Captain A. Saunders had a stroke of luck in this way, for a lion, after seizing him and carrying him some distance, suddenly let him drop, for no accountable reason, and then walked away, leaving him only a little damaged by the encounter. Lieutenant Molony, R.A., had an equally wonderful escape from a lion, though subsequently he fell fighting in Uganda. He had wounded a lion, which charged him and knocked him down. He lay on the ground, face downwards, and, shielding his head with his arms as best he could, waiting for the end ; but the lion just gave him one bite in the back and moved off. It is certainly remarkable that Selous, who must, in the course of his long African experience, which began when most of my generation were at school, and few of the next were born, have shot scores of lions, was never damaged by one, though, as already related, he was all but knocked out of 
the race by both elephant and buffalo. Lord Delamere was badly mauled by a lion in Somaliland, but escaped with his life. A sadder case was that of one of the Mashonaland Pioneers, in the time of Cecil Rhodes. A lion got into his tent one night and bit off one of his hands. The lion was driven off, but the poor fellow died of his wounds. A yet more recent victim of a lion was Mr. Grey, brother of the Secretary for Foreign Affairs. In I908 a Canadian trooper in the Transvaal Police, named Eagle, a man of very powerful physique, was killed by a lioness, though not before he had kicked her to the point of death.

Of all the stories of escape from lions after being seized, none, I think, equals that of Mr. Wolhuter, a Transvaal game ranger, on August 26th, 1903. As told by himself in the Journal of the Society for the Preservation of the Wild Fauna of the Empire, the story was as follows: It seems that he was riding alone, about an hour after sunset, with a big rough-haired dog. Suddenly the dog ran forwards, barking, and $\mathrm{Mr}$. Wolhuter saw some indistinct forms moving in the bush alongside the road, which he took to be reedbuck, or at any rate some sort of antelope. The last animal he thought of was a lion, as, curiously enough, he had been on the look out for lions for some time and always without 


\section{THE WILDERNESS AND JUNGLE}

success. Well, had he only known it, he was going to have his fill of lions that evening. No sooner, in fact, had he whistled to the dog to come back than he saw a lion on his right, preparing to spring on him. There was no time to put up his rifle, but he instinctively snatched his horse round and thereby saved it, for the lion, missing its mark, merely clawed it as he passed. The horse bounded forward and unseated its rider, galloping away, with the lion in pursuit and the dog after the lion. Meanwhile Mr. Wolhuter fell almost into the jaws of a second lion. It seemed, indeed, to catch him almost before he reached the ground, seizing him by his right shoulder and trotting with him a couple of hundred yards to the foot of a high tree. He had none of the pleasant oblivion to pain recalled by Livingstone when in a similar predicament, but suffered agonies and thought that his end had surely come. Suddenly an inspiration came to him in his dark hour. He remembered the great sheathknife that he carried at his right hip. It might, for all he knew, have fallen out in the scuffle, as it was always loose. Moreover, the lion had his right arm in its teeth. Yet, with great presence of mind, he managed to reach behind him with his left hand, and to his relief it grasped the handle of the knife. He then coolly stabbed the lion twice in the heart and 
THE VENGEANCE OF THE WILD 255

once in the throat, and the brute, mortally wounded and bleeding to death, dropped its prey and staggered away. Shouting at it, to complete its confusion, Mr. Wolhuter backed towards the tree, up which he clambered as quickly as he could in his condition. He was only just in time, for, though the wounded lion had no more fight left in it, the other, having failed to come up with the horse, now returned, probably thinking to share the meal. It was, however, closely followed by the dog, and that gallant brute worried it so effectually that it too retired. Mr. Wolhuter, now thoroughly exhausted, was eventually rescued from the tree, with great difficulty, by his native servants, and, though he suffered badly from shock and blood-poisoning, he ultimately recovered from an adventure that must be unique in the annals of African sport. In his opinion, these lions were not man-eaters, but were probably after the horse. As that had gone off, with one lion in pursuit, the other probably took what it could get and turned its attention to the rider. As a post-mortem examination of the dead lion showed that it must have been starving, this was in all probability the correct view of the case.

The strength and cunning of the African elephant make it less dangerous only than the lion, and it has had many victims, including 
256 THE WILDERNESS AND JUNGLE

Prince Rospoli in Somaliland and Colonel Armstrong in Uganda, while it was in Uganda also that Mr. York was killed by an elephant that he had hit with both barrels. He made a dash for the nearest tree, but the enraged monster was too quick for him. Mr. F. L. James was killed by an elephant on the West Coast of Africa. He had wounded the animal and was following it up in very high grass, when it suddenly charged and ran its tusk right through his chest, so that he died within the hour. Mr. Ingram was killed under similar circumstances, and it is a sad, but interesting fact, that a well-known sportsman, Mr. Lort Phillips, was present on both occasions. An Englishman named Firmin was killed by an elephant in Matabeleland; another named Attrill by a female elephant in the Addo Bush, and the elephant's victims also include the Swedish traveller, Wahlberg, and, most recently of all, Mr. Gerald Longden. Other sportsmen have been more fortunate, though escape from such encounters is rare. The extraordinary luck of Selous has already been noticed, and the late Mr. Arthur Neumann had a still closer shave, for a cow elephant knocked him over on one occasion before he could put up his rifle, and then she knelt over him and drove her tusk through his arm and ribs, breaking several of the latter. That he was not killed on 
the spot is little less than miraculous. It is well known that elephants often seek to avenge their dead. Major F. G. Talbot tells me that, having on one occasion shot an elephant, he was serenaded all that night by several others which had assembled for the purpose outside the dak bungalow in which he was sleeping. A somewhat similar story was published in The Field. It seems that a bull elephant had been shot and cut up, and its remains were taken on a cart to a neighbouring rest-house. Its mate followed up the trail, broke the cart to pieces, and threw the remains in the road in front of the gate.

The tiger has also claimed many victims, yet in less number than the lion and the elephant. Of natives it kills more than are ever counted, but natives run peculiar risks with which Europeans need not reckon. Among Europeans killed by tigers mention may be made of Lieutenant Grant, Mr. Lewis Gordon, and Captain Sexton, and I heard of another case during the present year. The list of those who have been terribly mauled by these animals is a much longer one, the best-known case being that of the late Colonel Sir E. Bradford. In these encounters, it must be admitted, the sportsman's reckless disregard of danger is often the tiger's best ally. I have to thank Major Murray for the following story of how, as a case in point, an 
officer was badly wounded through his own want of caution in circumstances which should have dictated extreme prudence. Major Murray was having the jungle beaten one evening, towards some machans in which he and his friends were to be posted, and earlier in the day he walked a little way into the jungle in order to see that his instructions had been carefully carried out, as the least mistake in constructing machans is certain to spoil sport. Suddenly a tiger appeared. He raised his rifle and fired, wounding the animal, which at once retreated into a neighbouring ravine. Being familiar with the ways of wounded tigers, he had the good sense not to follow it alone, but went back to camp and told a brother officer what had happened. Unfortunately, he was persuaded against his better judgment by the latter, who insisted on their returning at once to finish off the tiger; so back they went and found the animal lying under a bush in the ravine. Major Murray now fired again, and again hit it, whereupon it charged. The other now got in two shots, both of them hitting the tiger in the neck, but failing to stop it, as a result of which he was badly mauled before his friend could shoot it dead. This wanton risk of life and limb is a pity. No one can help admiring the courage which makes little of even so formidable an adversary as a wounded tiger, 
but those who play the terrible game of the jungle should play to win. After all, a single human life is worth a great many tigers.

Only last year a European, a mere lad, had a wonderful escape from a tiger in Burma. As the story is told in the Pioneer Mail, he was out near Hmawbi after deer, with two companions, and the party met a number of natives, armed with spears, who besought them to shoot a tiger that had been caught in a trap. The hero of the adventure set out with some of the native spearmen to do what they asked, but it soon became apparent that the tiger had got loose. Quite suddenly it stood before them, snarling and growling, with portions of the broken trap hanging by the chain to its neck. The animal's right foreleg was also broken, and if it had not been handicapped in this manner it would assuredly have been the young sportsman's last encounter with tigers. The spearman who was showing the way fainted without further delay, and the other natives made their way into the higher branches of neighbouring trees with equal promptness. The boy and the tiger were left face to face. The boy fired, the tiger fell; but it was on its feet again and upon him like a flash. It got his left leg in its teeth and crushed it terribly, and it also clawed his right knee and thigh. The boy fell on the guide, who at this moment 
260 THE WILDERNESS AND JUNGLE

fortunately (though not for himself) recovered consciousness and staggered away. The tiger, reluctant to see another course of his dinner escape, dropped the boy and hurried after the native. It was found dead next day, and the boy recovered slowly but surely from his wounds.

The leopard is another very dangerous beast. The natives dread it everywhere, for it is less cowardly than the tiger, more indifferent to the presence of man, and also able to climb trees and attack from above, which is a serious matter in the jungle. Many Englishmen have been mauled by leopards in both Africa and India. Captain Stigand, N.A.R., was one of the victims in Africa, and Major Barras ( $15^{\text {th }}$ Bombay Infantry) had a bad encounter of the kind in the Deccan. Mr. Van der Byl, one of those sportsmen who have been at close grips with the leopard and escaped, gave me some particulars of his adventure, which occurred in Rhodesia. He owes his life, in fact, to a lucky shot of his, which knocked out the leopard's two long canine teeth at the moment of its charge. He had wounded it with his Mannlicher, and he followed it up, both of them running their hardest. When the animal had gone about three hundred yards, it disappeared from sight, and, as he afterwards concluded, must have sat down and waited 
THE VENGEANCE OF THE WILD 26r

for him, for as soon as he came within thirty yards of it, the brute charged straight at him. In this desperate pass, and without time to take deliberate aim, Mr. Van der Byl fired full in its face, with the lucky result alluded to above. Nextmoment the leopard seized him and bit him badly, when one of his native servants ran up and pluckily killed it with an axe. Had the long teeth not been knocked out of either jaw, the leopard would have bitten fatally. From this and other experiences, Mr. Van der Byl has arrived at the opinion that a wounded leopard is even more likely to charge than most beasts.

Bears are not the most dangerous brutes in the wilderness, but a wounded "sloth" bear sometimes comes rolling downhill on its enemy at an extraordinary pace and inflicts dreadful face-wounds with its teeth and claws. Many of the jungle-men in parts of India bear eloquent testimony to its savagery. General Kinloch told me a story of one of these bears killing an officer in the R.A. and a forest officer, and General Gatacre mentioned that Mr. Neave, of the Indian Civil Service, was so badly mauled by one many years ago that he too died of his wounds. The grizzly bear is the fiercest and most dreaded of all the tribe, which is not surprising when we remember that it can still charge and kill a man even after it has been shot through the heart. Mr. 


\section{THE WILDERNESS AND JUNGLE}

Caspar Whitney once told me an extraordinary story which proves this. Some thirty years ago, in the State of New Mexico, a prospector, named Boyd, was so badly bitten by a grizzly bear that he died a fortnight after the accident. The two of them were out for meat, and the bear charged suddenly out of covert. Boyd shot it, as was afterwards discovered, clean through the heart, but it rushed at him and did terrible execution before Mr. Whitney could put a bullet through its brain. Female bears, with cubs to defend, are even more dangerous than the wounded animals of either sex, and I remember being told in the Caucasus that, only a year or two before, a shebear, who had been robbed of her cubs, had killed two Russians, members of a scientific expedition exploring that range.

The buffalo and bison are also a source of great danger, chiefly because of the cunning with which, when wounded, they lie in ambush, circle round their pursuer, unseen by him in the high grass, and suddenly, without warning, dash out on him from a wholly unexpected quarter. The Cape buffalo, indeed, seems always to have regarded the vengeance of the wild as its special mission. It was one of these animals that tossed Selous and killed his horse in I874, and, some years later, $\mathrm{Mr}$. Thomson all but suffered the same fate in 
THE VENGEANCE OF THE WILD 263

Masailand. Von Koppenfels, the explorer, was another of the African buffalo's victims, and $\mathrm{Mr}$. de Fries was badly gored by one, but recovered. Two very sad cases of sportsmen being killed by buffalo occurred in 1876 and I889. In the first of these, Mr. Robert Russell was killed while on a hunting expedition with his friend, Mr. Guy Dawnay, while in the second, Mr. Dawnay himself fell a victim to a wounded bull of the same species. The circumstances of these tragedies were not quite the same. It seems that Russell wounded his buffalo in open ground, with not even a tree handy in case of a sudden charge. The charge came and was, unfortunately, fatal, for by the time Dawnay could get to the spot there lay his friend and the buffalo side by side and both dead. Thirteen years later, unwarned by his friend's fate, poor Dawnay also paid the supreme penalty of shikar. Having followed up a wounded buffalo in thick bush, under the shadow of Kilimanjaro, he was gored by the crafty brute, which had kept quite still in the high grass, never moving till he had passed its hiding-place, when it suddenly rushed out at him. Curiously enough, he had often been heard to express the conviction, after a very wide experience of big game in both Africa and India, that of all wild animals the African buffalo was the most dangerous! It seems a 
264 THE WILDERNESS AND JUNGLE

cruel irony of fate that one imbued with such respect for these animals should in the end be killed by one! According to Selous, the Cape buffalo used, in days before they had been much hunted, to be unsuspicious, peaceful animals, and there were untrodden wilds in which, when the white man first shot game in them, he found it difficult to induce the buffalo to move out of his path, just as, not long ago, I heard of a fox in Devonshire which the huntsman had to flick three times with his whip before it would move. All this friendly feeling is gone in the Africa of to-day. War has been declared these many years. On the whole, it goes against the wild creatures, but now and again the persecuted buffalo gets its own back.

It is not only the great carnivora or heavy wild oxen that are dangerous. Even wounded antelopes must be approached with caution, if only out of regard for the terrible weapons with which they are equipped. A sable antelope has been seen to kill a native, transfixing him with one sweeping blow of its curved horns. A waterbuck once killed a Canadian of immense strength. He had wounded the animal and, as it lay still on the ground, he imprudently stooped to lift it from the ground. With one supreme effort, the dying animal jerked back its head and drove one of its horns 
THE VENGEANCE OF THE WILD 265

into his leg, whereupon death ensued from blood-poisoning. Lord Egmont tells me of a lively encounter which he recently had with a male bushbuck, from the worst consequences of which he was saved by the courage of a friend's dog which happened to be with him at the time. Here is the account in his own words :

"While out one day with a party of friends driving bushbuck on the south coast of Natal, I was posted on a ridge of land between two large patches of bush. I had foolishly loaded my breechloader with two different cartridges. In the right barrel I had a 'looper' cartridge, which only holds about eight very large shot, and in the left a cartridge with No. 6 shot, which are suitable for pwiti, or small buck. An inkonka, or male bushbuck, broke out of the covert above me, and then swung round to my right at the moment when I fired my right barrel, with the result that only a couple of the big shot hit him. This, without inflicting any serious damage, enraged the animal, which at once charged me. Forgetting that there were only small shot in the other barrel, I fired straight at his face as he came at me, and when he was still perhaps twenty-five yards away. This turned him, for he dashed down into the dense bush behind me. Disliking to let a wounded buck get away, I followed, keeping to the narrow path that led through the middle of the scrub. Before I got to the buck, 


\section{THE WILDERNESS AND JUNGLE}

it became evident that a big dog belonging to a friend of mine-a big white lurcher, a cross between a bull terrier and a Kaffir dog-had the animal at bay, so I slipped in two more looper cartridges and then came suddenly on the two of them. The moment the buck caught sight of me, it charged clean over the dog and came right at me. The bush was too thick to allow of my dodging the charge by stepping aside, and there was time to get my gun up, so I just threw myself backwards into the thick prickly bushes. Next moment I received a tremendous blow in the lower part of my waistcoat and thought I was pierced and done for. The buck then turned to charge again, but the plucky lurcher dashed in and seized it by the nose. This gave me my chance, and I shot the animal. I then looked to see the extent of my own damage, and was surprised to find that it amounted to nothing at all. The reason why I got off so easily was that the animal was doubly handicapped, since not only had one of its horns been broken off short for some time, but my charge of small shot must also have all but blinded it."

More dangerous than even the floods of African rivers are the crocodiles that hide effectually in their muddy water. Two very remarkable cases of escape from crocodiles are recorded in The Field. In one of these, a Mr. Barnes was crossing a muddy stream in Rhodesia in pursuit of a wounded elephant 
when a crocodile seized him by the leg. What he did, without a moment's hesitation, was to put the muzzle of his gun under water and fire. The crocodile let go and made no further attempt to molest him. The other case, which happened to a native, was even more extraordinary. The native had been seized by a crocodile in the Niger. First it took him by the legs. Then it let go, and at last it took hold of him again. The boy, with great presence of mind, stuck his thumbs hard into its eyes, which had the desired effect of making it loose its hold once and for all. He was terribly bitten about the head and arms, but he managed to recover.

The vengeance of the wild is a risk that sportsmen take without grumbling. In fact, it lends flavour to big game hunting, and it will last until there are no more wild creatures left to shoot. It is a fair risk, and it would be a fairer if the vengeance always fell on the real culprit. Unfortunately, this is not the case. A reckless tourist blazes away at all manner of animals, wounding an elephant or a hippopotamus without taking the trouble to follow it up. The enraged animal then wreaks its vengeance on the next human being who passes that way. For this reason, as also on 


\section{THE WILDERNESS AND JUNGLE}

humane grounds, it behoves every sportsman to let no wounded animal go free. There may, and there will, be occasional cases in which this is impracticable, but they should be admitted as seldom as possible. The interruption of nightfall when following up wounded game is frequently made an excuse, but in such cases the sportsman may have been to blame in firing late in the day at an animal he was not sure of killing. One thing is certain, and that is that between ourselves and at any rate the great carnivora it is war to the knife. The fear of man is still on every beast so long as he leaves it unmolested, but a wounded lion loses all fear in its one thought of revenge. 
THE TAMING OF THE WILD 



\section{IV}

\section{THE TAMING OF THE WILD}

First came the gardener, Adam; then Cain, tiller of the ground; last, Abel, "keeper of sheep." Some people believe, for reasons best known to themselves, that man bent the wild animals to his will before he grew vegetables; but why should we suppose that the possession of domestic animals came before agriculture? The Swiss Lake Dwellings, to which we owe so much of our knowledge of human life before the period we call History, contain, even in the Stone Age, relics of both corn and cattle, without any indication of which came first. Personally, I would rather trust the evidence of Genesis. Not until Adam had been put in the garden "to dress it and to keep it," not before Cain had helped his father in such simple gardening, perhaps improving on his methods, as young people will, do we come to the shepherd Abel. Not until after the Deluge do we find Abraham on trek with his horses and his camels. The "happy family" in the Ark makes very superior folk smile. How, 
272 THE WILDERNESS AND JUNGLE

they ask, could the lion and the lamb exist in the same boat? The answer is perfectly obvious. Terror of the rising waters made a common bond. The same thing, on a smaller scale, has been seen again and again in floodtime, when the most unlikely fellow-travellers are found crowded on floating wreckage, the strong too terrified to molest the weak, and the weak forgetting even their natural enemies in their all-absorbing fear of drowning. As Tennyson says :

"Lion and stoat have isled together, fool, In time of flood."

Fire, like flood, draws the most ill-assorted fugitives together, and when a forest fire sweeps across the open, it drives before it an amazing stampede, lions and fawns fleeing side by side, eager only to outstrip the death that roars and blazes at their heels.

First, then, we may assume, came agriculture in its crudest form. Adam dug, no doubt, with his hands. Cain may have used flints. Then would have come the inspiration to attract and tame some of the less formidable wild animals of Western Asia, making them do useful work. The males were killed for food. The ewe and cow gave milk. The skins of both were used for clothing. We cannot know which was the first animal to come under man's 
dominion. One view, more widely accepted than it deserves, is that he tamed horses first, and then used them in the capture of others less swift to escape. But, in the first place, so fleet a creature as the wild horse must have been the most difficult to catch. In the second, it would not have been of the least use to its owner in chasing such mountain types as sheep and goats, the ownership of which is clearly of great antiquity. These had to be followed on foot. A case of a flock of wild African mountain sheep being caught and tamed during severe winter weather has been told in these pages, and the lambs and ewes would doubtless have been secured most easily. An animal like the sheep would, in fact, have made a good subject for man's earliest experiments in taming the wild. Here, again, common sense and the Book of Genesis agree. They often do.

To some extent, no doubt, the taming of wild animals would be increasingly difficult as time went on, for they would lose that trust and confidence which seems to have inspired them even in the early days of navigation. It is said that the first canaries ever seen by sailors perched fearlessly on the men's shoulders, and the penguins of the antarctic ice are still stupidly unafraid. Even the jaguar was known of old as amigo del Cristiano. The jaguar did not know the Spaniard then. It does now. 


\section{THE WILDERNESS AND JUNGLE}

The word "taming" means something over and above merely accustoming wild animals to the presence of man and teaching them to take food and to allow themselves to be handled. This is done in every Zoo, and is, after all, no more than any schoolboy does with his "pets." All manner of singular creatures are made pets of, and one of the most curious I ever heard of was an immense South African rat, which Major Herapath saw at the front in the Boer War. He tells me that when he first saw the animal it was sitting on the saddle of one of the drivers of a gun team. The battery was inspanned, in readiness to move at a moment's notice, but the drivers were dismounted. The rat's story was rather pathetic. It had belonged to a Boer who was taken prisoner at Paardeberg, and it had always lived on its owner's saddle. The Boer had been much attached to his pet rat and, not knowing where he might be sent, or what would become of it, he had given it to the driver, begging him to be kind to it. Fortunately the Boer rat took a great fancy to the enemy, and whenever the gun was on the move, even when galloping, it would nestle securely on the inside of the man's leg just above the knee. When, however, he dismounted, the rat stayed on the saddle. Yet it was by no means friendly to anyone but its new owner, and when Major Herapath tried to make 
friends, it showed its teeth. When a rat shows its teeth, a little distance lends enchantment to the view.

Nor is even the employment of an animal to do useful work quite all that is meant by domestication. It is only so much of it as is comprised in taming. The Indian elephant is the faithful servant of man, carrying him in the jungle, either on errands of peace or in operations against tigers, stacking his timber in the teak forests of Burma and elsewhere, and even feeding the saws in the Chinese timber yards at Rangoon with logs, using both tusks and trunk and very rarely getting foul of the machinery. Yet the Indian elephant has not appreciably changed in appearance during all its centuries of domestication. It is outwardly the same to-day as its wild kinsmen in the jungle. If, on the other hand, we compare the woolly sheep of our English pastures with the straight-haired sheep of the Himalaya, we shall find their coats as unlike as the heads of a negro and a Norwegian. It is really difficult to believe that a South Down ewe and an Ovis Ammon are members of the same family. Humped Indian cattle, English bulldogs, massive shire horses and Yorkshire pigs are quite different in appearance from any wild animal in existence, and their transformation has been the work of untold centuries. Such change is 
276 THE WILDERNESS AND JUNGLE

ostensibly for the better, though it would be hard to point to the improvement of the donkey in a coster's cart on the splendid-looking wild ass of Somaliland, and, unless viewed from the standpoint of the farmer, our tame cattle and pigs are poor specimens to look at compared with their magnificent cousins of the wilderness.

Man's prerogative of dominion over the fish of the sea could be exercised in one way only. First he caught and then he ate them. But his sway "over all the earth" bore a higher interpretation than the savage right to kill. No doubt he was a hunter before becoming a pastoralist, but the arts of the pastoralist are nobler than those of the chase. The negro was never a tamer of the wild. He has, of course, owned herds and flocks, and he has even been known to train an occasional hunting-dog to assist him in killing other animals. As a rule, the pastoral life is associated with a gentle disposition, and shepherds are rarely warriors. Yet there are exceptions to this rule, and the Somali herdsman is not only a born fighter, but also a merciless robber of all weaker than himself, so that his peaceful occupation has not moulded his character. The lack of physical strength in many of the Asiatic races most noted for their domesticated animals is a strong argument in favour of will-power as the chief factor in the taming of the wild. Many a 
mahout, from whose uplifted finger huge elephants cringe in terror, is an abject little figure of a man, and the undersized Todas quell their fierce buffaloes with a glance, though Europeans dare not go near them for fear of being trampled. I have seen little children in Syria, along the valley of the Jordan, tyrannising over their bad-tempered buffaloes and making no greater account of them than if they were sheep; and those who know the Eskimos of the Arctic Circle tell us that the savage sledge-dogs allow themselves to be cuffed and kicked by the fearless children in a manner that they would never tolerate from a European hand.

The negro, then, is a failure in this respect. He can destroy, but he cannot subdue. The Arab, on the other hand, who has invaded Africa from his home in the East, is a master of the art. With him he brought the camel. Had he been established in the land sooner, he might even have saved the African elephant, though it is doubtful whether anything short of the arts of the Hindu would have availed. The destruction of the wild elephant of Africa and the employment of the tame elephant of India show the difference not indeed between the elephants, but between the negro and Hindu. The black groom may coerce, but it takes the mahout to cajole. It is perhaps 
too late to domesticate the African elephant on a considerable scale. It seems to be a matter of argument whether the war elephants with which Hannibal crossed the Alps were African or Indian, but in all probability they were the latter. Yet experiments have proved that, with proper treatment, the African elephant is as patient and docile as the Indian. The famous "Jumbo" was quite as amenable to his keeper's influence as the Indian elephants in the same building, and in the French Congo baby African elephants have been taught to draw carts. Unfortunately the greed for ivory sealed the fate of the grandest animal on earth. It is useless to blame individual hunters. English, Portuguese, Dutch, Belgian and negro, they have all wallowed in the blood of elephants for centuries, and the native alone had the excuse of needing the meat to save himself from starving.

The case of the African elephant is worth a little further consideration. I do not say that the giant unites in its tremendous frame all the virtues of the horse, ass, mule, and the rest. It is slow in its movements, and it is very expensive to feed. Yet, as we have daily proof in India, it can do work that is beyond any other animal. If it costs five times as much as a horse for its day's keep, it carries ten times the load. Nor, it must be re- 
membered, is the cost of keeping an elephant in a menagerie any clue to what it would cost in the jungle. The elephant can carry half a ton for hours at a stretch, and over short distances it can carry three times that burden. Its speed may not be great, but its endurance is remarkable. There are swampy tracts in the heart of Africa, which we are gradually reclaiming, and here, in spite of its tremendous weight, its caution and surefootedness would give it the advantage over many draught animals of lighter build. Not only, like the horse and camel, can it pull or carry, but, unlike any other animal, it can also push logs or other weights with its powerful forehead, being able, it is said (though on the authority of what test I have never been able to discover) to push far more than it can pull. Its trunk, moreover, is an organ at once so strong and so delicate as is unequalled elsewhere in the animal world. Writers of other days used to describe the elephant as exclusively a dweller in the plains. In the absence of further evidence, it did not occur to them to associate so huge a beast with the power of climbing the sides of mountains, but we now know that elephants ascend to a considerable height up the slopes of Kenia and Kilimanjaro, and this suggests that the animal may be used for mountain transport where mules are not available for 


\section{THE WILDERNESS AND JUNGLE}

the work. The elephant feeds on the march, tearing up juicy tussocks or pulling down leafy boughs without stopping. To all its virtues in life may be added a value after death far in excess of that of any other animal. The dreadful waste of this noble creature, hitherto regarded only as so many tons of meat and pounds of ivory, has certainly been a crime past forgiveness. Is it also past atonement?

If anything is to be done, it must be done at once. In the first place, the trade in elephant ivory must be put an end to by international agreement. It is clearly useless to prohibit the slaughter of elephants in the territories of one Power if their tusks are valuable merchandise at the ports of another. Ivory is not a necessary of life. Even were it a foodstuff of the masses, the elephant should no longer be slain to provide it. It is, on the contrary, only a luxury for the making of billiard balls or toilet articles, for which bonzoline and ebony serve respectively quite as well. We shall never again see elephants roaming, as once they did, south of the Zambesi, but the remnant might at any rate be saved for all time in Government Reserves farther north, and experiments might even be inaugurated in taming the younger members of the herds with a view to their employment in clearing the African forest, and thus, even 


\section{THE TAMING OF THE WILD 28I}

at the last, redeeming those responsible for the partition of Africa from the reproach of having completed the evil wrought by their predecessors. For these experiments mahouts should be imported from India at Government expense, and a keddah outfit, with tame elephants and their attendants, might also be introduced so as to capture the wild elephants and subject them to the influences found irresistible in the East. It remains, of course, to be seen whether the blandishments of the Indian keddah elephant would have the same effect on individuals of the other species, but the experiment is, at any rate, worth trying, and if the State would not spend the necessary money, some South African millionaire might, without feeling the cost, place a sufficient sum at the disposal of one of our colonial governors and thus do something for Africa really worthy of his reputation,

The camel, which we know from India westward as far as the Atlantic coast, making itself at home from Port Said to Mogador, might strike the careless observer as the typical domestic animal of Africa, but both the camel and the "native" who tamed it came originally from Asia, and both are well suited to the Sahara, where patience, long-suffering, and philosophic indifference to the blows of fortune 
282 THE WILDERNESS AND JUNGLE

are called for more frequently than in happier lands. Kismet is the Arab's creed, and it is written on the face of the camel. I imagine that there are happy camels, but I never saw one show any pleasure on its face. Those who have camped for weeks with the camel and its driver are struck by the strong resemblance between the two. Was it St. Augustine who said that we are all God's beasts? At any rate, the camel answers the description in more senses than one. When travelling with a camel caravan, I have endeavoured to show the brutes kindness and consideration. I have insisted on the men loading and driving them more gently than is their wont. I have seen that they got their evening barley before going to my tent to dine. I have even attempted overtures, such as patting their shaggy necks. It would be quite as satisfactory, for all the response they make to such caresses, to pat the tyre of a motor bicycle, and much less risky. Admirers of the animal say that its dirty habits and treacherous nature in Morocco are the fault of its Arab taskmasters. Yet, though the Moor often treats his camel brutally, I understand from Major Baden-Powell that even the well-cared-for regimental camel, of which he had considerable experience in the Egyptian campaign, is no better. In parts of Asia, it is true, a 
closer bond of sympathy unites the camel and its owner, and, according to Kipling, the Bikaneer men have bred "thieves' camels," which, in place of gurgling and groaning whenever they rise or kneel, are perfectly silent lest they should betray the whereabouts of their rascally masters. A silent camel would be a boon at times when the restless bubbling and muttering of the brutes keep one awake half the night. As they exist in Morocco, the camel and camelman are much the same. They belong to the sand and stones of the plains and are useless in the lighter air of the mountains, where they must be replaced by the muleteer and his mule. The great virtue of the camel is its extraordinary endurance, and that, in the climatic conditions in which it is required, covers a multitude of sins. It may lack the fire and dash of the barb, or the gentle manner of the ass, or the comfortable ambling gait of the mule. Yet the "ship of the desert" is sun-proof and indomitable. True, unlike other ships, it comes to grief in water, or even on wet ground, collapsing irrecoverably ; but in dry weather it is unequalled, carrying its four hundredweight day and night, swinging along in the heat of the noonday sun or in the bitter cold of the desert night. That it is out of action in rainy weather matters little in the Sahara, where rain is rare, 


\section{THE WILDERNESS AND JUNGLE}

and we do not want camels for use in Lapland any more than we need reindeer in Kordofan. If it does not live exactly on air, the humblest and most meagre of fare serves its purpose. It smacks its pendulous lips over such dreadful vegetables as prickly pear, oleander, artemisia or tamarisk. It revels in mimosa or salsola. Thanks to the wonderful storage apparatus in its stomach, it can go without water for days together. Its working life lasts twenty-five years. When its hour is near, its Moslem owner finishes it off with his knife, else he would not be permitted by Koranic law to eat its flesh, for animals that die a natural death are not accounted clean food by followers of the Prophet. In life the female camel provides her master with milk for himself and his young horses, camel's milk being considered excellent nourishment for swift steeds of noble race. In death, her skin makes splendid covering for the tents of the desert men, and her flesh is eaten with relish. The flesh of a young camel is not to be despised. Of that of one that has worked by the sweat of its brow for twenty-five years let others speak who know, but the Arab is little more of an epicure than his camel and doubtless appreciates its flavour.

All the camel's greatness is in its body. Its mind, when not a blank, seems hideous. We 
may, of course, misjudge the creature, even after long spells in its company, but even its apparent cheerfulness in adversity seems to be nothing more than stupid indifference, while its treachery and ingratitude soon make themselves felt.

Most camels are yellow in colour, of a hue that is eminently protective in the desert. Now and again, away from the cities, the traveller may see a white one, but it is never for sale. In early summer these animals lose the heavier coat of hair, which shielded them against the intense cold of winter nights, for Nature looks well after the deer and camels, and changes their winter and summer clothing for them.

The saddle camel, or méhari, is of superior breed to the jemeel, or commoner baggage animal. This tall, leggy animal, with the deep chest, powerful shoulders, and muscular hindquarters, is the dromedary. Many people seem to think that the word dromedary has reference to the number of humps on the creature's back, but this is not the case. It is the shaggy Bactrian camel of Central Asia that carries two humps, and the Arabian, which is the familiar kind from the plains of India to the cornfields of Morocco, that has only one.

The camel has been used in warfare from the earliest times, and we read of it in the engage- 


\section{THE WILDERNESS AND JUNGLE}

ment in which David routed the Amalekites. The first general of modern times to see its possibilities was Napoleon, whose flying camel columns were imitated by Napier in Sind, where he had at one time no fewer than twentyfive thousand. The Gordon Highlanders rode on camels in the Indian Mutiny, each trooper with a native driver, and the Scots Greys had their camel corps in 1885 , each beast carrying two men and their kit. The French, who, with their Algerian experience, have had unrivalled opportunities of testing the camel in war, use it on their punitive expeditions in combination with horses. The camels are led with the horses until the moment when the enemy is sighted. Then the men are transferred to the camels and are thus able to charge on fresh mounts. In these African wars the hardy character of the camel makes it simply invaluable. It is no fair-weather friend. It goes day and night. It eats and drinks if there are food and water; if there are not, it goes without. Its feet are impervious to the heat of the burning sand. If the hot wind blows up from the desert, the camel simply shuts its eyes and nostrils, just as we might close the windows of a house to keep out the dust. The swiftest camel will easily cover a hundred miles in ten or eleven hours, though it should not be expected, when travelling at that pace, to carry 
more than $250 \mathrm{lbs}$., including its rider. The slower baggage camel, on the other hand, going on level ground, takes four hundredweight, equally divided in two panniers. I understand from one who served with the Suakin Field Force that the camels imported from India were much more satisfactory throughout the campaign than those from Egypt. This is remarkable, as the assumption would naturally be that the animal born in the country would be better fitted to do the work required of it in that climate. But the result proved otherwise.

Camels have been introduced into various countries, even as far as Australia. They were long employed on farms in both Italy and Spain, but not with lasting success. The natives of both countries are slow to adopt new ideas, and the mule and ass were probably sufficient for their needs. America also had its fit of enthusiasm for the camel, though, like some other popular crazes in that country, it died a natural death.

The llama, the equivalent of the camel in South America, is another surefooted beast of burden, priceless for transport in the Andes, but not apparently, so far as its moral character goes, showing any marked improvement on its Asiatic cousin.

The only horned animals, at any rate south 
of the frozen lands, familiar in harness are oxen. The yak, in Tibet, and the buffalo, in Turkey, are the common draught animals in everyday use, and the Tibetans even ride their yaks, though I never saw a Turk astride a water buffalo, save only little children at play. The yak has lately been introduced into Manitoba, the Duke of Bedford having presented six of these animals to the Canadian Government as the nucleus of an interesting experiment. If the animal should justify the expectations of Mr. Thomson Seton and defy alike frostbite and the mosquito-Canada's chief menace to her visitors-future generations of Canadians will be confronted with the curious spectacle of these fine Asiatic oxen grazing on the prairies once trampled by the buffalo.

These oxen are slow but surefooted, docile, and amenable to discipline. The yak has the great advantage of being available for mountain transport, whereas the majority of oxen are used only for ploughing or road traction in the plains. Their strength is enormous. The yak, it is true, carries only three hundredweight in the hills, but some of the loads drawn, willingly or otherwise, by buffaloes over the stony roads in Turkey must be tremendous. On the whole, the Turks treat their animals far better than the majority of European nations, particularly those that dwell along the shores of the Medi- 
terranean. This they appear to do more from a common-sense view that it pays than from any motive of sentiment. I never saw a Turk, old or young, pet or fondle his horse as you may see even rough drovers do in England, but, on the other hand, there is none of the spiteful cruelty only too common on the dusty roads of Italy or the Peninsula. Winter visitors to the beautiful island of Madeira will not need any reminder of the brutal manner in which the natives goad the little bullocks that drag sledges laden with fat tourists up the steep roads to the hotels and quintas in the hills. It is a disgusting sight, and the R.S.P.C.A. might, with great advantage to the bullocks, establish a branch at Funchal. If it could enlist the co-operation of the authorities, under pressure from the English tourists to whom the island owes so much, it would soon have its hands full of prosecutions.

One other horned animal must be mentioned as a most important beast of burden in the boreal climates suited to its constitution, and that is the reindeer, the one and only member of its family in which the hind also carries antlers. It is an improvement even on the camel, for, in addition to providing its owner with labour during its life and, after its death, with meat and a serviceable hide, it yields oil with which to light the darkness of the 
northern winter. Like the camel, also, it can make a sufficient meal of Nature's leavings, and any old patch of moss or lichen not too deep under the snow to be dug out with its hoofs is uncovered and eaten.

Two reindeer, harnessed in a sledge, can pull six or seven hundredweight over hard snow. Such is their work in winter. In the summer-time they are either ridden or used as pack animals, each of them carrying at least a hundredweight and a half. Thousands of Siberian reindeer have been imported by the American Government into the wilds of Alaska, and their timely introduction has probably been the means of saving the Eskimos from the extinction to which they seemed doomed when whaling expeditions had scoured their coasts and exhausted their supply of natural food.

To the frozen north likewise belong the sledge-dogs, particularly valuable in those regions because, being meat-eaters, they can be fed on the blubber and waste of whale or walrus, or on fish, whereby the forage problem is solved without the trouble of transport. Both the large Eskimo dog, which is very close kinsman to the wolf, and the smaller and handsomer Samoyede have been tamed in this way, and their domestication must be of ancient date, for old bone carvings show them drawing sledges. Arctic explorers have used them at 
the Poles. McClintock, Nansen, and Peary all owed much to their sledge-dogs and readily admit their indebtedness to these enduring animals. Six of them, harnessed to a sledge, will go seven miles an hour pulling six or seven hundredweight, and an average performance of forty miles a day has been maintained over a distance of two thousand miles. The "huskies" of the Indians are extraordinary workers, but are also vicious brutes and very unfriendly towards strangers. Yet the children cuff and kick them without fear, and the dogs never turn on them. In summer-time, when there is no work for them to do, the packs are turned adrift and run wild, but at the beginning of winter, driven probably by the increasing difficulty of foraging for themselves, they return to their old quarters and take up their burden again. They do not seem to need regular rations, and can pick fishbones clean in a manner more suggestive of wolves than tame dogs. Their worst disease is a form of madness, which makes them useless for work, but does not infect anyone they bite in the same way as the rabies of southern breeds.

Draught dogs are also used by the street hawkers in the cities of Belgium, and to a lesser extent in France. In Antwerp and Ghent they are a familiar sight pulling milk carts or vegetable barrows. They are not so 


\section{THE WILDERNESS AND JUNGLE}

inhumanely treated as some tourists hastily assume, and their lot has been much improved by the prizes given by the authorities for the best-kept dog every year. The harness is admirable, distributing the strain and allowing the animal to lie down when tired. Though few of the present generation seem to remember the fact, draught dogs were common in the streets of London until prohibited by law. It is an open question whether their abolition was called for by popular sentiment against real or imaginary cruelty, or whether it resulted from the more prosaic complaints of the noise made by their barking at Covent Garden Market at daybreak, which must certainly have been very annoying to residents in that quarter of the town. Whatever the cause, they were declared henceforth illegal. Perhaps this sweeping edict was a mistake. Sweeping edicts often are. With proper supervision of their treatment, and with due attention on the part of the vigilant officials of the R.S.P.C.A., many of our big breeds would be all the better for a little hard work. As it is, our mastiffs and great Danes are merely ornamental, degenerating rapidly for want of exercise to brace their muscles and keep them in condition.

Some animals have been reduced to a state that is best described as half tame. Such are 
the eagles and falcons used by sportsmen in hawking all manner of game, from gazelles to rooks, and the so-called "cheetah" of Indian rajahs, which has more than once been referred to in these pages. How tame the captive eagles of Kirghiz falconers may be at home I have no knowledge, but if one may judge of their manners by those of "tame" hawks in mews, as I remember them at the King's House, Lyndhurst, they are hardly pets for the stranger to toy with as he might with lovebirds. The latest suggested use for eagles, which sounds almost too fantastic to be taken seriously, is for attack on aeroplanes and dirigible balloons in time of war. It is said that French officers at Nice have actually been engaged in training the birds, by means of baits, to swoop on anything in the shape of a balloon or flying-machine. It might not be impossible to train them in this way, but what would the occupants of air-craft be doing to allow the eagles to come near enough to do any damage? The cheetah, or hunting-leopard, is also harmless only to his own keeper. It is taken when quite young, chiefly by setting nooses round the foot of a tree on which these animals are known to sharpen their claws, a habit they share with all cats large and small. The process of taming is a slow and difficult business, and its success depends in great 


\section{THE WILDERNESS AND JUNGLE}

measure on the continuous chatter of native women and children, who are able to raise such a clamour as would daze an elephant. Bound and blindfold, the captive is given very little food, and is subjected day after day to this ordeal, so that, as might be expected, it soon loses all its spirit, and the village children are able to make a playmate of it without running any risk. Nevertheless, Europeans may be advised to treat the grown-up animal with respect, for any misplaced confidence will be found wrong policy. A most interesting experiment was tried in the Paris Zoo not long ago with one of these hunting-leopards. The animal was suddenly brought close to the bars of a paddock containing two wildebeests. The leopard immediately crouched in the attitude of a cat about to spring, and the antelopes, on their side, plainly showed their dread of the intruder. The strangeness of this conduct lies in the fact that neither animal could previously have ever seen the other, for the wildebeests had been born in captivity in a park, and the cheetah had been caught very young in a region of Africa where there are no longer any wildebeests. It had, moreover, also been reared in captivity, and had never been trained for the chase. Yet instinct at once asserted itself irresistibly on either side. The antelopes recognised their hereditary enemy, and the 
leopard realised that these were creatures that it was expected to kill.

The cormorant and otter, which eastern fishermen train as allies, are also no more than half tame, and the same may be said of the more homely case of the silkworm. The worm, it is true, spins its silk, and the moth lays her eggs, for the owner's benefit, but we cannot regard these unresponsive insects as recognising those who look after them to the same extent as bees are known to do.

It is a remarkable fact that when animals that have been tamed revert to the wild state, they seem to run wilder than ever. Indeed, these "feral" animals, as they are called, are generally better dead than alive, for the mischief of which they are capable is almost incredible. Our own house cats escape to the woods and live by poaching, and these are the worst enemies the keeper has to reckon with, giving him far more trouble than such natural poachers as the fox and stoat. A solitary elephant, escaped from captivity, is sometimes more destructive than even the ordinary "rogue." There are many cases of socalled "wild" cattle, camels and horses, which are in reality only descended from tame stock. Thus Australia has no native animal of its own larger than the kangaroo, and the ancestors of the "wild cattle" in the extreme north of 


\section{THE WILDERNESS AND JUNGLE}

Queensland were left there by the Dutch when they abandoned their settlement at Port Darwin, to which they had brought over the buffaloes from Sumatra. The same may be said of the wild camels of Andalusia, which originated in some that were imported by a Spanish grandee to work on his estate.

Other creatures have been tamed on a small scale. The eland, grandest of all antelopes, has been driven in harness, and its strength must certainly be prodigious. That handsome striped horse the zebra has also been subdued, though neither of these achievements was the work of the negro, who contented himself with catching them in pitfalls, or shooting them with poisoned arrows, and then eating them. We may, of course, from our superior pinnacle of civilisation, condemn the negro, but we should in fairness remember that at times he must kill game or starve. And what sort of example, after all, do we set this primitive son of Africa? Simply doing for amusement what he does to keep alive. The zebra is not everyone's choice of a domestic animal, though it has been seen in harness even in this country. Now and then wild zebras show every inclination to fraternise with farm animals, and there was a case of one attaching itself to the cattle on a farm in Zululand, making itself quite at home, and refusing 
to be driven away by the dogs. As a rule, however, the zebra is an uncertain quantity when it comes to handling it. I have seen six or eight men spending the best part of a quarter of an hour in throwing one and getting on its bit and bridle, and it was a lively sight. On one occasion a "tame" zebra was known to go up to a man who lay asleep on the ground and bite his ear off. The man had done the zebra no harm, and we may assume that the zebra bore no malice. It was just playfulness.

It would be unreasonable, no doubt, to argue from this particular case the unfitness of the whole race of zebras, but the fact is beyond dispute that they are vicious as they are handsome, evil-minded brutes, better suited, in fact, to the circus ring than to the serious business of everyday work. Nothing but a shortage of horses could warrant increased attention to the taming of the zebra, and the coming of the motor-car has in great measure superseded them both.

Such are the animals which man has tamed to do his work. We do not, in these days of mechanical traction, want any new animals in harness. Even horses are falling into disuse, and will soon be seen only in the hunting-field, since the enjoyment of riding for its own sake has gone out of fashion, and our vans and 


\section{THE WILDERNESS AND JUNGLE}

omnibuses are driven by petrol. If we feel any regret that more of the wild animals should not have been tamed, it is on purely sentimental grounds, for we know that this is their one chance of survival. The revelations of the cave remains clearly show that it was not until man had learnt to tame the horse for work that he left off killing it for food. It was when he discovered that horses could be ridden that he was content to eat other animals that could not. 
THE PASSING OF THE WILD 



\section{V \\ THE PASSING OF THE WILD}

People grieve over the breaking of some valued piece of old china, which probably took but a few hours to make, and which may possibly be replaced. What, then, shall be said of the extinction of a species which took untold thousands of years in the moulding, and which can never more be seen alive? A few grains of powder, and a few more of lead, undo in sixty seconds the work of sixty centuries.

The wild creatures are going, slowly but surely. The Powers concerned in the partition of Africa have, a little late in the day, made game laws to protect the little that is left of the hordes of oxen, antelope, and elephants that once abounded in that continent; and the American Government, moved, after long indifference, by the eloquence of $\mathrm{Mr}$. Hornaday and other enthusiasts, has likewise established sanctuaries for two or three threatened species of the New World. In a country like the United States, where beef is cheap and wild game no longer forms the daily food 
of even the protected Indians, themselves likely to share the fate of the buffalo they slew so mercilessly on the rolling prairie, the formation of these Game Reserves offers little or no difficulty beyond the expense of their maintenance and policing. In Africa, on the contrary, where there are still many millions of negroes who have to live by their bow and spear, constant trouble arises, and the authorities are confronted with protests and objections, chiefly on the ground that these Reserves encourage two very different enemies of man, the lion and the tsetse-fly. There is, it is true, much difference of opinion regarding the actual connection between this terrible insect and the preservation of buffalo and other big game, but, until at any rate the truth has been established beyond all doubt by scientific inquiry, public opinion will be hard to convince. The dread of the tsetse-fly arises from the fact that it is Nature's appointed carrier not only of rinderpest, a cattle disease ruinous to the farmers, but also of sleeping-sickness, that mysterious and hitherto incurable malady which does not even spare white men, and which inflicts terrible damage on the natives. As regards the lion, however, there can be no two opinions. The king of beasts is invested with a good deal of romance in story-books, and, viewed from a disinterested standpoint, 
he is a magnificent creature; but in the eyes of the farmer he is just as much vermin as the fox in England. While, therefore, persons who do not live in Africa, and who can see the lion when they want to in its cage at the Zoo, would probably hail the extinction of the lion with dismay, the farmers and stockowners on the spot would feel nothing but satisfaction if the last lion in Africa were shot, trapped, or poisoned. The natives, it is true, suffer much less from the lion than those of India do from the tiger, if only because in many parts the lion inhabits open country, in which sudden ambush is more difficult than in the jungle. It is even said that some of the Bushmen live, like jackals, on scraps from the lion's table, and these would be the only mourners at the death of the last. A century ago lions must have swarmed over South Africa, abounding in parts of the country where none have been seen these twenty years. The Boers, when trekking out of Cape Colony in the eighteenthirties, slew no fewer than 380 , and large numbers were also slain by the Moselekatse and other fighting tribes. Lions can never again become a menace to human life in the more settled parts of South Africa, though, even on the beaten track, an accident is occasionally reported. Yet the dominion of the lion was very different in the days of the 


\section{THE WILDERNESS AND JUNGLE}

pioneers. They found the lions hunting in bands and killing immense numbers of antelopes, and whole tribes of natives were even compelled to live in trees so as to be safe from them. The extent to which they preyed on antelopes was such that every sportsman who bagged half a dozen lions must have been the means of saving the lives of hundreds of antelopes.

Dangerous beasts, like warlike tribes, cannot be exterminated in a day, and even reduction of their numbers is full of difficulty. The most familiar case of legislating for the suppression of noxious beasts and reptiles is that of the Indian Government, which pays out immense sums every year for the destruction of wild beasts and venomous snakes, a warfare of civilised man against his natural enemies which Sir Alfred Lyall regards as the perpetuation of a blood feud. There is sudden death in the path of the native who goes barefoot, and every year twenty thousand victims are slain by the cobra and krait, while tigers and leopards account for two or three thousand more. This mortality continues, even though Government pays out two hundred thousand rupees a year in rewards. It is inconceivable that the maintenance of Game Reserves should seriously encourage the survival of lions, for there can never be any question of prohibiting 
the shooting of these animals, even within the Reserve itself, so that it may, in a sense, be regarded as a bait to bring them within reach.

Man is a hunting animal. Where he kills wild animals for sport only, he can be made to pay dearly for his amusement; his bag can be limited to one or two heads of each animal; and he can be altogether prevented from shooting certain creatures that are becoming rare. Where, on the other hand, he kills wild animals to save himself from starvation, it is not only difficult, but would be actually inhuman, to put any difficulty in his way. The distinction is well shown in the view which Provincial Governments in Canada take of the porcupine. This familiar animal has many virtues to commend it. It is slow in its movements and easily caught. For all its formidable armour of quills, it is quickly killed by a blow on its sensitive nose. Roasted over a slow fire of leaves and birch-bark, it makes a very excellent dish. To a hungry man who has lost his way in the Canadian forest there can be few more welcome finds, and the authorities are so alive to the value of the "Lost Man's Friend," as it is appropriately called, that a heavy fine is imposed on anyone who kills a porcupine unless he is in need of meat. 
The causes that have led to the total disappearance of some wild animals, and to the serious dwindling in the numbers of others, within the last hundred years are many and various. The sportsman is only one of them, and in the opinion of those best qualified to judge he is not even the greatest offender. So far as Africa goes-and it is with Africa that we are chiefly concerned in this glimpse at the passing of the wild-ivory-hunters, native and European, doomed the African elephant and incidentally shot antelopes wholesale to feed their camp. I have a very interesting letter on this subject from Major Stevenson-Hamilton, Warden of the Transvaal Game Reserve, in which he says :

"Personally, I consider that purely sporting expeditions make but little permanent difference to the status of the big game. British East Africa, at present overrun by touristsportsmen, many of whom are but little conversant with the ethics of this kind of hunting, perhaps forms an exception. We cannot overlook the dreadful tales of destruction of the most wanton kind, wrought by individuals who, from their position, might have been expected to know better, but, after all, these are isolated and may be regarded as exceptional.

"Two factors, I think, conduce to extermination. The rest may be taken as merely subsidiary. 
"These are:

"( I) Trade in ivory, skins, and horns (and, in South Africa, in the dried meat known as 'biltong'), mainly supplied by white hunters, professional or semi-professional, though natives armed with guns are also constantly employed in some parts. The extermination of big game in the high veldt really dates from the days when biltong, horns, and hides acquired a value in the coast towns. The Boer farmers would have taken another half-century to extirpate the wild animals if they had killed game only for their own consumption. Professional hunting is still in vogue on a large scale in Portuguese territory, as well as in German East Africa and the Belgian possessions, and there is a section of the settlers in British East Africa and British Nyasaland that desires to see it introduced.

"(2) Natives equipped with firearms. Nearly all the game in sections of Mozambique and the Zambesi Co.'s territory has been exterminated during the last twenty years without European assistance. Many of the natives are excellent shots. What their firearms lack in quality they make up in number, and the hunters live on the spot. Save when engaged by European traders, this hunting is 
308 THE WILDERNESS AND JUNGLE

mainly for domestic purposes. It is only since they have acquired firearms that the natives have been able to effect any appreciable diminution in the numbers of the game, which were not sensibly reduced by the huge drives and annual hunts formerly in vogue.

"As regards firearms generally, far more damage is done by wounding than by killing outright, especially on the part of Europeans. It is my belief that, more particularly since the introduction of small-bore rifles, three or four animals at the least escape to die for each one that is bagged. When the man behind the gun is incompetent, the proportion of wounded is naturally greater. Rinderpest is, not without reason, blamed for much of the diminution of big game, but a species left to itself would recover from an epidemic in less time than that covered by a human generation, provided sufficient breeding stock survived."

Major Stevenson-Hamilton's allusion to epidemics suggests passing reference to this factor in the dying out of wild animals in South Africa. Rinderpest, which, like "horsesickness," has more than once crossed the Zambesi, depopulating vast regions of their game, is said to be conveyed wholly through 
the agency of the tsetse-fly, and it seems to have been communicated from the tame herds to the wild with terrible results. The tsetse, like the mosquito, is an insect which haunts water, and in consequence the buffalo, inyala, koodoo, and other creatures of thirsty habits suffered worst, whereas the thick-skinned rhinoceros was almost immune from the disease.

As already mentioned, lions must have been terribly destructive to the antelopes, and the same may be said of the packs of huntingdogs that can run down and kill even an eland.

There are other influences which have killed off the big game. We need not go back to the climatic changes of the earth which swept away the giant reptiles, leaving man's heritage free from such nightmares. It is, however, obvious that the big game of Europe, with the single exception of the Scandinavian elk, has retreated before the march of civilisation. With the cutting down of forests and draining of marshes and building of towns, not to mention the operations of agriculture and the farming of sheep and cattle, there is no longer room for the bear, boar and wolf. The North American bison had to go in like manner. Its extermination is generally attributed to the railway gangers and to the trade in its meat 


\section{Io THE WILDERNESS AND JUNGLE}

and hides ; but in any case, even had it been spared another decade, it would have had to disappear in order that the prairies might be prepared for the greatest wheat crops the world has ever seen. Sentiment is a pleasant luxury, but it may be a costly one, and it must give way to the growing needs of a great nation. It is impossible to think of these thundering herds of dangerous wild oxen still in possession of the prairies. They might just as well have been left to the Red Indians. From a less sternly practical standpoint, no doubt, there is something horrible in the fate that so swiftly overtook the "buffalo." Within the memory of living men there were still two or three millions of these splendid creatures left in the wild state, for it is on record that, as late as the winter of $1878-9$, two hundred thousand buffalo hides were shipped to Europe, and a year or two earlier more than four thousand of these animals were slain in the Yellowstone Park, which has now for many years been a sanctuary for all wild life. As a result of this hurried slaughter of an animal that, for all its size and strength, was easily ridden down and shot wholesale, not more than two or three thousand American buffaloes are left alive on earth and even these are no more than half wild, since they live, under more or less continual observation, in the State parks of Canada 
and the United States. One such herd is domiciled in Canada's National Park at Banff, in the heart of the Rocky Mountains, where I have stood less than fifty yards from them without suspecting their presence till an official showed them to me. The Park has a fine muster of them, including the Flathead herd, four or five hundred strong, which was purchased by the Canadian Government for $£ 40$, ooo. Curiously enough, this famous herd was Canadian by descent, as its four original members, which were still living at the time of my visit, had been driven over the border into Montana in 1873 , the year that witnessed the virtual extinction of the great southern herd which had been cut off from the northern herd by the building of the transcontinental railway six years earlier. They have a beautiful home at Banff, planted with dense thickets of spruce and larch and carpeted with columbine and the characteristic American flower known as "Indian Paintbrush." It is also pleasant to reflect, without boasting, that the reserve at Banff is nearly twice the size of the Yellowstone Park and, in fact, the biggest sanctuary in the New World. How it may compare for size with some of the projected extensions of animal sanctuaries in British Africa I have no knowledge. These "parks" must not be confused in the reader's mind with 


\section{I2 THE WILDERNESS AND JUNGLE}

those trim lawns grazed by tame deer and enclosed in palings which represent our notion of parks at home. The park at Banff covers three and a half million acres and is therefore equal in extent to nearly all three ridings of Yorkshire together. Within it are busy mining cities, deep lakes, mighty rivers, mountains ten thousand feet high, impenetrable bush, and hundreds of miles of horse trails. In such a wilderness the buffalo, moose, and elk can lead an existence as peaceful as they did before man came on the scene to break up their homes. There is another small herd in the Yellowstone Park, though poachers have succeeded in taking toll of it, so that few remain ; but a third herd, which roams at large in some wild country near the Great Slave Lake, and a small band in the Wichita Forest are still doing well. The European bison is protected in much the same way by the Prince of Pless, in Silesia. This species was threatened with extinction, having been reduced from nearly two thousand survivors in 1857 to less than five hundred in 1892. The total has again reached nearly fifteen hundred, half of these being protected by H.M. the Tsar in his forests of Bielowitza and Swisslotsch. This magnificent bison is not, as sometimes stated, the same animal as the ancient aurochs, which man hunted in the Stone Age. That type, 
regarded as the ancestor of our farm cattle, is long since extinct.

The absolute and irrevocable extinction of an animal is obviously more regrettable, at any rate on sentimental grounds, than its disappearance from areas in which it once abounded. The wild boar and the bear have long since been exterminated from the island of Britain, where no one wants them back; but they survive in neighbouring continental countries. On the other hand, the true quagga of South Africa, the Antarctic wolf of the Falkland Islands, and the sea-cow (named after Steller) of the Behring Sea are specifically as dead as the dodo and the great auk. They can never be restored, and all that remains of them is in the museums. The manner of their disappearance may be told in a few words. The true quagga, an animal closely resembling existing zebras, was exterminated by the Boers, who slew it for the sake of its flesh, and the last living individual died in captivity in the year 1883 . As it seems, from contemporary evidence, to have been more amenable in harness than other zebras, it is a pity that the Boers should have been allowed to drive it off the face of the earth.

The existence of the Falkland Islands wolf came to an abrupt end in 1876 . Great numbers of these animals were killed by the Gauchos, 


\section{THE WILDERNESS AND JUNGLE}

whose meat the hungry wolves stole in the most audacious manner. Even more were slaughtered for their skins, which, though not taking high rank as furs, had a market value that made the chase worth while. The final blow at the Antarctic wolf was struck by the Scotch settlers, whose sheep suffered so severely from its attacks that the farmers were not long in poisoning the remnant of the wolf population. Reports of survivors were brought home by travellers long after the creature was extinct, but these were in every case disproved.

Steller's sea-cow, a gigantic cousin of the manatee and dugong, was first butchered to feed the shipwrecked crews of Behring's expedition in search of the North-West Passage, and Steller was the naturalist and doctor on board the explorer's ship. Other sailors and hunters then slaughtered the unfortunate creature, which was compelled to visit the shallow creeks in order to browse on the seaweeds that it could not find in the deeper water, and the result was that the last was seen alive in 1854 . Here, then, we have three animals, of very different haunts and habits, exterminated by man during the nineteenth century. Two of them furnished food, and the third came under the head of vermin ; and it is, apart from his love of sport, with one or 
other of these objects that man kills most of the wild animals. The wolves, indeed, offered irresistible temptation, since they combined two of these conditions, devouring the farmer's sheep when alive and yielding saleable skins after death. No one, in fact, can reasonably regret their disappearance.

In fact, with the possible exception of the beavers and squirrels, which may do appreciable damage in other ways, the majority of the animals killed for their skins are enemies of the stockowner. Bear, ermine, lynx, marten, mink and otter are among them, and of their skins, with those of the beavers, the Hudson's Bay Fur Company's warehouse at Montreal has been known to receive nearly 135,000 in a single year. This seems a terrible toll to take, but at the same time these animals do irreparable damage during their lifetime, and this makes it less outrageous to kill them for the sake of their warm and beautiful skins. No such excuse can be found for the plumehunters, or rather for the silly fashion that gives them profitable occupation. These assassins have devastated the groves of Florida and the forests of South America with disastrous results. Less than half a century ago, myriads of snow-white egrets were still to be seen wading along the muddy creeks that open on the Gulf of Mexico, and humming-birds 
316 THE WILDERNESS AND JUNGLE

swarmed in the forests of Brazil. To-day the latter are rare where once their jewelled plumage was a sight so common as to attract little notice, and of egrets no fewer than a million and a half have been known to be slain in a single year.

Civilised nations, waking up to the fate that has overtaken some creatures and that threatens others no less interesting, regretting the quagga and anxious to avert the same doom from the "white" rhinoceros, are taking counsel as to how this praiseworthy object may best be attained. They are, it must be confessed, a little late in their deliberations, for much of the mischief has already been done, but it may be that game sanctuaries will be the means of preventing more. It is, of course, essential that these reserves should be as little artificial as possible, the animals being left to forage for themselves, else they would soon lose their wild habits and degenerate into mere park animals, like the so-called wild cattle of Chillingham, Chartley, Vaynol and other breeds. I say nothing against these park cattle. I had those at Vaynol under close observation for a week, and they are such interesting survivors of an ancient race that their owners have made the nation their debtors for the care with which they have preserved them. Yet no one would compare them to the genuine wild oxen 
of the wilderness, since their very whiteness is the result of artificial selection. Something can be done in this way on even a small scale. Two Boer farmers, for instance, have long preserved the black wildebeest, which is elsewhere extinct, on their farms in the Orange Free State. Had they not done so, it is probable that the South African War, which had disastrous effects on the antelope population of that region, would have sounded the knell of the species.

A condition of success in this scheme of sanctuaries is that the animals should be preserved in their natural haunts. Only in their native climate can they remain wild in the true sense of the word. Transplanted to other homes, they become virtually animals in captivity. Save as an interesting hobby of private individuals, like the Duke of Bedford, not much can be said in favour of proposals to set wapiti, eland, or other exotic deer and antelopes at liberty in English woodlands, and they are not, at any rate, a proper enterprise for national support. Apart from the vagaries of the British climate, which is something quite different from that to which these animals are accustomed in their own homes, ours is a small island, and the migrations which these creatures make at different seasons of the year would soon bring them to the seashore. 


\section{THE WILDERNESS AND JUNGLE}

It is in South Africa that the passing of the wild has most extensively been accomplished under the eyes of men still living. What a spectacle must have met the eyes of the great hunter Cornwallis Harris, who, in the year I836, only three-quarters of a century ago, actually shot springbok on the road between Graaf Reinet and Grahamstown, and who on one occasion saw so many quaggas, wildebeest and hartebeest that he described the face of the country as chequered black and white with the moving herds, and calculated that he could not be looking at less than fifteen thousand head of game! What of the Transvaal to-day? The elephant, rhinoceros and eland are gone, exterminated for the most part by the Boers. There was every excuse for the way in which they slaughtered wild animals during the war, for they must often have been hard pressed for food. Those, however, who best know the Boer hunters in time of peace declare that they have no sense of honour or spirit of sport, but evade every game law the moment they are out of sight of a policeman, slaying wantonly like wild dogs, and camping close to the Portuguese border, so that they can escape from justice, from whichever side of it detection comes. It was the Boers, too, who destroyed all the once-abundant game of Natal, trekking after meat in the foothills of the 
Drakensberg, and killing every animal they came across. Nor, as will have been gathered from Major Stevenson-Hamilton's remarks on the subject, can the part played by the native in the story of African game be ignored. Selous also regards the native in possession of firearms as the worst offender of all, and he ought to know. Kind people at home, with a mania for championing their coloured brothers, insist that the native should on no account be hindered from killing wild animals that provide meat for his larder. At first sight, this plea looks reasonable, but the truth of the matter is that most of the natives who shoot game are paid for their services. Not one of the great settled tribes of the Matabele country between the Zambesi and Limpopo are regular meat-eaters. They do not even kill their own cattle for food, though they eat all that die from natural causes, and, if these are too long dying, the native would kill an occasional antelope or buffalo with his own primitive weapons, which are therefore sufficient for his domestic purposes. The possession of a gun or rifle merely enables him to do this with less exertion and in shorter time, and there is no object in encouraging laziness in native races for whom time has no value. The destructive powers of armed natives are sufficiently proved, if such evidence were needed, by the continued 


\section{THE WILDERNESS AND JUNGLE}

decrease in the number of elephants in parts of Africa where white ivory hunters, of whom the late A. H. Neumann was one of the last, no longer operate. It is, in fact, the native hunters who to-day supply the market with nine-tenths of the ivory that changes hands at the great sales.

The massacre of elephants, cows as well as bulls, has been conducted without restraint. In India, where the shooting of elephants, other than certified "rogues," has been forbidden for the past thirty years, the animal has maintained its numbers, though Sanderson's prediction that the prohibition would eventually have to be removed has not so far been fulfilled. Formerly, however, though so easily tamed in the service of man, the Indian elephant was destroyed as wantonly as the African in our day, and Sir Victor Brooke alludes in passing to the shooting of five in three hours one morning before breakfast. The African elephant, which is not protected to the same extent, is in desperate straits. The greed for ivory seems undiminished. One firm of cutlers alone admitted, not many years ago, having taken the tusks of between twelve and fifteen hundred elephants every year, in addition to which regular demand it kept no less than eight tons of ivory in reserve. Neumann bagged fourteen of these huge creatures, most 
of them cows, in an afternoon, and a native, armed with a rifle, destroyed seventeen in Somaliland in one day. And all for what? That we may brush our hair with ivory-backed brushes and play billiards with ivory balls. So long as the bristles are good, it makes no difference whatever with what material the brushes are backed, and ebony is quite as decorative. As for billiard balls, it is quite as easy, with practice, to play the game with those made of bonzoline and other substitutes.

The rhinoceros, for the butchery of which there is even less commercial justification, has been treated in the same fashion. Andersson once killed eight of these huge brutes in five hours, and even Mr. Roosevelt and his son shot no fewer than nine of the vanishing "white" kind on their African trip. I have the warmest personal regard for the strenuous ex-President, but it would have been still warmer if he had taken only one of these heads back to his country.

One of the factors in the diminution of big game of late years has been the wonderful improvement in the machinery devised for its slaughter. When it is remembered that a 450 Winchester, charged with ninety grains of powder and three hundred grains of lead, can send a bullet clean through eight inches of hard wood at fifty yards range, it will be 
322 THE WILDERNESS AND JUNGLE

seen how little chance even thick-skinned animals stand against such weapons.

The work of extermination is going on all around, and not merely in the big game countries with which we are here chiefly concerned. Unfortunately, the rarer a creature becomes the higher is the price put on it by collectors, who thus bribe hordes of robbers to invade Nature's sanctuaries in search of their ill-gotten booty. The large copper butterfly and many beautiful orchids were exterminated in this way. Nor are even dangerous animals without their uses, and the American Government has found itself compelled to protect the Florida alligator from the greed of the skin-hunters, because it was realised that the disappearance of the alligator was followed by an intolerable increase in the numbers of rats and other rodents ruinous to the crops. The case of the fur-seal does not come within the scope of a book concerned with big game, any more than that of the whalebone whale, but both have been wastefully slaughtered, the disappearance of the seal having been the subject of international conferences and conventions for the more thrifty conduct of pelagic sealing.

As has been shown, there are three means of staying the destruction of big game. The first is by imposing a heavy licence, whereby 
the sportsman is not only made to contribute to the cost of game reserves, but is restricted as to the number of each animal he may kill. The second is by ordaining a close season, which may last, like our close seasons at home, for only part of each year, or which, in cases where it is desired to let a threatened species re-establish itself, may extend over a number of years, during which that species is contraband. The third is by closing specified areas, which thereby become sanctuaries in which wild animals may live in peace.

The success or failure of game laws, speaking generally, is a matter too wide to allow of discussion in these pages, and the political aspect of such restrictions is still further from the scope of the book. Without these laws, however, it is safe to say that not only our pheasants and partridges, but also all manner of other wild creatures which live in the woods would long ago have become as extinct as the bear and wolf. In "free" countries, like Italy and France, where the game belongs for the most part to the people, it is a possession in name only, for the game is gone. Such simple game laws as those which suffice in England are obviously not applicable to those forests and deserts in which big game still find their last refuge. At the same time there are tracts of continental Europe which bear so 


\section{THE WILDERNESS AND JUNGLE}

close a resemblance to the wilderness in other continents that a brief glance at European ideals of preservation may help us to arrive at the best means of achieving the same object elsewhere.

Shooting rights on the Continent mostly go with ownership, though in Central Europe there is a system of joining small holdings, each of two or three hundred acres, and putting the sporting rights up to public auction. The average close time lasts, as with us, six months, but longer periods are prescribed in the case of a few animals that it is particularly desired to protect. In Switzerland there is, as in America, some confusion, owing to the clashing of the Federal law with the more local enactments of the Cantons. The general Federal close time lasts a little more than six months, and the Cantons have power to close entire areas for indefinite periods. Much of this power has been wisely exerted for the better protection of the chamois, and it is a pity that similar enlightened efforts were not in time to save the steinbock, or ibex, of the Alps, which survives only in the preserves of the King of Italy.

In Spain, save in the royal preserves, the destruction of wild game is unchecked, and poaching is carried on openly.

Turkey looks on wild animals with char- 
acteristic Moslem indifference, and any restrictions on indiscriminate shooting are framed rather to put difficulties in the way of carrying arms, though much even of this restraint has disappeared since the Constitution.

The case of the elk, in Norway and Sweden, is perhaps of greatest interest to English sportsmen, who have long looked on Scandinavia as a playground that affords exceptional shooting and fishing. Until recently, that splendid deer was not protected, and in 1894 a thousand elk were shot in Norway alone. Native opinion wakes slowly in the north, but it seems at length to have realised that the elk was falling off in numbers, and, what was of more practical interest, that it was being slain by rich foreigners who might be willing to pay for their amusement. The Störthing accordingly raised the tax on such sport, with the twofold result that the extermination of the elk has been indefinitely averted, and the not too prosperous treasury of the country has likewise benefited. Formerly the elk in Sweden was protected for various periods, but the new regulation in Norway is much more effectual, as the animal can now be shot only during twenty days of the year, beginning on the tenth of September.

Many of the States of America have followed the French example of taxing the 


\section{THE WILDERNESS AND JUNGLE}

foreigner more heavily for his sport than the native. Otherwise, there is no "native question" in America, for the Red Indian, where not kept as a park animal in Government Reservations, is in a fair way of following the buffalo. Nor is the native question a difficulty in framing the game laws of India, since not by any means all of the natives eat meat, and the vast majority outside of the cities follow the more peaceful occupation of agriculture. In Africa, on the other hand, as has already been pointed out, the meat-eating natives are a factor of some complexity. The opinions of authorities have already been quoted as holding armed natives to be the worst offenders, and no game law could be effectual that did not take their operations into account.

Morocco is practically the only settled country in Africa without game laws, and when the French have completed the "pacific penetration," as it is called, of that country, they will probably frame restrictions for the protection of the aoudad and gazelle. These are, with wild boar, the only game to be taken into account, for the bear and stag of the Atlas (or of that portion of the range, at any rate, within the borders of Morocco) are either imaginary or extinct. Mohammedans do not approve of game laws any more than they concern themselves with forestry. It may be 
that their fatalism condemns such provision for future generations, and that they hold themselves privileged to slay every animal and cut down every tree for use at the moment and without thought of those who come after.

Elsewhere in Africa close times, reserved areas, and expensive licences limiting the bag have been in force for the last twenty years or more; but such game laws, which may work smoothly enough in small and wellpoliced countries elsewhere, are often nugatory in the interior of a vast continent like Africa. As a case of the ease with which such regulations may be evaded, mention may be made of the prohibition of exporting ivory or trophies from the coast ports during nine months out of the twelve. This is admirable on the face of it, but what is to prevent hunters collecting such material during those months and then taking them down to the coast as soon as the close time is ended? Again, it is well that large sums should be exacted for these big game licences; but, on the other hand, the very fact of having paid so much money induces the licensee to get his money's worth.

The game laws of both North America and South Africa are very complicated, but some of the provisions are of general interest. Thus antelopes are protected throughout the summer months in the Transvaal, Zululand, Swaziland, 
Natal, and the Orange Free State. Licences may cost as much as $£ 75$ in Bechuanaland and $\mathscr{E}_{50}$ in Portuguese South-East Africa, but the sums, as well as the close times, are constantly being altered. It is pleasant to observe that the penalties for infringement of these laws are really exacted from white men, two of whom, some years ago, served a year's imprisonment in default of paying fines of $£ 120$ for shooting two white rhinoceroses on a reserve in Zululand.

In Canada, where, again, we have Dominion law and Provincial law, there is a very complicated system of regulations. The deer, goats, and sheep of British Columbia are protected absolutely during nine months of the year, and non-residents have to take out a licence costing fifty dollars and allowing them to shoot, in each season, only two bull moose, two bull wapiti, ten deer, and five caribou, mountain-goat and mountain-sheep. Thus, with such restrictions, gunners no longer flock to British Columbia, as they did formerly, to make a business of killing. Visitors to New Brunswick have to take out a licence costing twenty dollars. There is some confusion in the matter of fishing licences, and on one occasion, when salmon fishing in the Miramichi, I was compelled to take out a Provincial licence, whereas others of my acquaintance 
were exempted. The game licence in Newfoundland is the most expensive of all, costing a hundred dollars. This is excessive, and one would view it more favourably if residents also had to take out a licence instead of being free to shoot as they please at very slight cost.

In India and Ceylon, very strict game laws have for some years been in force. In the Central Provinces, for instance, the cheetul and bison are specially protected, each licensee being allowed to shoot only two of each, whereas there is no limit in the case of nilgai or four-horned deer, or, of course, in that of tigers, bears, or leopards.

In Kashmir, yak and musk-deer are absolutely protected, and certain nullahs are closed against shooting. A licence, costing sixty rupees, allows the holder to make a limited bag, including one Ovis Ammon, one serow, one Tibetan gazelle, two markhor, six ibex, and so forth. Curiously enough, the number of brown bears is also restricted to six, but there is no limit for black bears. That is the summer licence. A winter licence is issued at half the cost, permitting the killing of a proportionate number of animals.

In the Nilgiris, the game laws are somewhat different. A shooting and fishing licence costs fifty rupees for the year. There is no limit to the bag, but no one may shoot the females or 
immature males of the bison, sambur, spotted deer, antelope, or ibex, and even mature males of sambur and spotted deer may not be shot if they have cast their antlers, or if their antlers are in velvet. The Governor in Council has power to fix approved close seasons from time to time, but landowners are at all times allowed to kill any animal that destroys their crops.

In Ceylon, "elk" (i.e. sambur), spotted deer, and red deer are protected in most of the provinces from June ist to October 3 Ist, though in the Northern Province the close time is shorter by two months, and in the NorthWestern Province by one month. No shooting is allowed between sunset and sunrise, and a game licence costs only three and a half rupees. A special licence, costing a hundred rupees, must be taken out to shoot an elephant, but no tuskers may be shot. A licence to shoot a buffalo costs twenty-five rupees. This issue of special licences allowing the holder to shoot one particular animal is in general vogue, but it has its drawback, for its tendency is to encourage commercialminded people to blaze away until they get value for their money. If, on the other hand, the money were payable only by results, at so much for each specimen, the gunner would be more inclined to hold his hand until sure of 
killing the game. Any measure, however good its intention, which prompts careless shooting, and the consequent wounding of animals that get away to die, is to be condemned.

The protection of big game, before it is too late, is a problem of not only sporting, but also scientific interest. Even looking at the matter economically, abundance of big game must always be an asset to the natives, who earn better pay as shikaris than in any of their other occupations, added to which wealthy sportsmen spend large sums of money on provisions and fodder. The scientific importance of some of these wild animals is also beyond all question. Who would have dreamt, a hundred years ago, that the study of a group of insects, heretofore regarded only as tormentors, would have solved the problems of yellow fever and malaria? Who would have thought it possible, a little later, to trace the carriage of sleeping-sickness to the tsetse-fly? We can never tell what may be learnt from the wild animals until we have studied them, and they cannot be studied after they have ceased to breathe. Even in the bird world, the dodo, great auk, and moa were exterminated almost before they had been described. To have driven these birds out of existence without even taking the trouble to know all that there was to know about them is a disgrace to 


\section{$33^{2}$ THE WILDERNESS AND JUNGLE}

civilisation. Science cries shame on this barbarous destruction of wild creatures without a thought for the species. Humanity cries aloud against the spoilers, and they are equally condemned by the economist. It is no argument to say that these animals have their market value when dead, for that only strengthens the case of those who plead for their protection for the benefit of future generations.

Unfortunately, it is not only those who make their living by shooting elephants and other animals who are to blame for the present state of affairs. That, of itself, would be bad enough, but it is worse to think that much of the scarcity of big game to-day is due to the greed for trophies. Everyone wants to beat the records of his predecessors and to kill either more or larger specimens than they. This is playing to the gallery, and is quite unworthy of the best traditions of shikar. It is true that the crowd does not applaud the gunner as it does the footballer, but it can gape in silly admiration at the trophies he brings home, without even making certain that he shot them himself.

The twentieth century has been already marked by much activity among those concerned in preserving the wild creatures from oblivion. At the dawn of it M. Foà, a French lion-hunter of distinction, suggested a kind of 
Zoological Peace Conference, at which the nations who have made Africa their own might sink their other differences and discuss the best means of saving what is left. When the earth was younger, forest, plain, and mountain were a paradise of big game. It would be futile to hope for the restoration of such conditions; it would, indeed, be impolitic to attempt it; and it might even be undesirable to realise it. Yet we should hesitate before we recklessly throw away the little that has escaped destruction. 



\section{INDEX}

Africa, 146-214

- Natives of (see Negro)

- Protection of wild animals in, 30I-4, 306-9, 320-1, 326-7 Agagir, Sword-play of the, 194204

Alaska, Brown bear of, 232

-, Reindeer introduced into, 290 Alligators, Digging out, 3I

-, Protection of, 322

America, Sport in, 50

Amigo del Cristiano (jaguar), 236,273

Andersson, Narrow escape from rhinoceros, 246

-, Rhinoceros slaughtered by, 321

Animals as they are, 46

Antarctic wolf, Extermination of the, 313,314

Antelopes, 205-9

Antlers of moose, 220 ; of sambur, 88 ; of wapiti, 224

Aoudad, Difficulty of finding, 2 I 2

Apes and monkeys, 149

Arab, Domestic animals of the, 277

- sword-hunters, 194-204

Arbuthnot, Capt. (adventure with red bear), 137

Ardennes, Wild boar in the, $8 \mathrm{I}$

Argali and snow-leopard, I27

Arizona, Venomous lizard of, 142 Armstrong, Col. (killed by elephant), 256
Arnold, Mr. Edwin (quoted), 98

Asia, Animals of, and Africa compared, 148

Ass, Wild, 276

Assam, Buffalo in, 86

-, Rhinoceros of, 73

Atlas Mountains, Stalking wild sheep in the, 212

Audubon, 31

Australia, Animals of, 3I, 239, 240

-, Camels in, 287

-, "Wild" cattle in, 295

Australian scenery, Sadness of, 32

Baboons, Destructiveness of, I 49

Baden-Powell, Major (quoted), 282

"Bad Lands," The, 37

Baker, Sir Samuel, 194

Banff, National Park at, 2 I6, 3 II

Barasingh (or Swamp-deer), Habits of, 9 I

Barras, Major (killed by a leopard), 260

Bears, Indian, 135-7

-, North American, 25, 27, 30, 228-32

-, South American, 237

-, Sportsmen killed by, 261

Belgium, Draught-dogs in, 29I, 292

-, Wild boars in, $8 \mathbf{r}$

Berar, 47 


\section{THE WILDERNESS AND JUNGLE}

Bible evidence of domestic animals, 271

, Lions in the, 96

Bicyclist pursued by a lion, 16 I

Bighorn sheep, Broken horns of, 217

Bikaneer camels, 283

Birds of India, 49

Bird song, Varying appreciation of, 46

Bison, Case of the American, 309

-, Protection of European, 312

"Bison," 83; at high altitudes, 85 ; cunning of, 86 ; scent in, 86

Black Bear, Food of, I 36

Blackbuck, Colour of, 93 ; habits of, 93 ; hunting with cheetah, 93, 94

Black fly in Canada, 215

Blacktail deer escaping notice, 25

Blood-poisoning from bites and scratches, I 35, 250, 25 I

Boar as a pet, 80 ; courage of, 74 ; hunting, $8 \mathrm{I}$; in Belgium and France, 80, 8I ; match for panther, 75

Boarhounds in France, 82

Boers exterminate the quagga, 204

- protect black wildebeest, 3I7

- slaughter lions, 303

Boleadores, Use of the, 238

Botanic gardens of Australia, 32

Bradford, The late Col. Sir E. (mauled by a tiger), 257

"Brain-fever bird," The, 46

Britain, Sport in, 43

British Columbia, game laws of, 328

- Empire, Sport in the, 45

Bronx Animal Park, The, 50

Brown Bear of Alaska, 232 ; of India, 137

Bruce, Mr. C. W. A. (quoted), 65
Bryden, Mr. H. A. (quoted), 193

Buffalo and tsetse fly, 210, 211

- asleep, 24

- in Syria, 277

- in Turkey, 288

-, Size and appearance of, 2 IO

-, Sportsmen killed by, 263

-, Vitality of, 87

Buitenzoorg, 32

Bulldogs, 275

Burchell's zebra, 204

Bushbuck, Encounter with a, 265

California, A forest in, 34, 35

Camel, Colour of, 285 ; in Australia, 287 ; in Italy, 287 ; in Spain, 287 ; in warfare, $285-7$; mind of, 285 ; taming of, 17 , $28 \mathrm{I}-7$; uses of, 284

Canada, Animals of, 215-34; backwoods of, 24, 27 ; blackflies in, 215; game laws of, 328 ; yak introduced into, 288

Caribou evicted by moose, 223 ; feet of, 38, 226; habits of woodland and barren ground, 226

Carnegy, Major (killed by an Indian lion), 95, 252

Cats, Lord Roberts and, 98 ; poaching, 295

Cattle-birds warn buffalo, II 4

- British "wild," 316

Caucasus, Bears in the, 262

Cave remains, Evidence of, 297

Ceylon, Absence of tiger from, 51 ; animals of, 5 I ; game laws in, 330 ; leopard in, I3I ; sambur, known as "elk," in, 88

Cheetah and wildebeest in Paris Zoo, 294; fight between leopard and, 167; hunting blackbuck with, 93, 94; method of capturing young, 293 ; taming, 293, 294 
Circus, Elephants in a, 72

- , panthers in $a, 128$

Civilisation, Retreat of wild animals before, 309

Cobra, Bite of the, I39; hood of, 139

Condor; Wonderful eyesight of, 239

Congo, Buffalo in the, 211; elephants tamed in the, 278 ; water-elephant in the, 183

Cormorant trained to catch fish, 295

Coyote, Cunning of the, 234

Crocodiles attacking bathers, 144 ; escapes from, 266, 267 ; females thought to be more plentiful than males (explanation of this), 142 ; in the sea, I 44 ; seizing dogs, 143 ; and human beings, 266,267

"Dark Continent," The, 146

Dartmoor, Solitude of, 23

Dawnay, Mr. Guy (killed by a buffalo), 263

Deer of India, 88-93; of North America, 219-28; of South America, 237, 238

Deer-stalking, 43

de Fries, Mr. (gored by a buffalo), 263

Delamere, Lord (mauled by a lion), 253

Desert, The, 35

Dewar, Mr. Douglas (book on Indian birds), 49

Dhole (see Dogs)

Dogs, Draught-, 29I ; seized by crocodiles, I 43 ; by leopards, 128 ; wild, 17,91

Domestic animals, $17,84,148$, 205, 27 I-98

Donkey and wild ass contrasted, 276

Eagles trained to attack aëroplanes, 293
East African Standard (quoted), 183

Eastern jungle, The, 29

Egmont, Lord (quoted), 265

Egrets, Slaughter of, 315

Eland in harness, 296 ; in the Kalahari, 207

Elephant, African, case of the, $277-81,320$; compared with Indian, 172, 277; food of, I73 ; mind of, 171 ; protection of, 174 ; senses of, 172 ; shooting in Rhodesia, I74-82 ; size of, 172 ; sportsmen killed by, 256 ; tusks of, 182 ; with only one tusk, 173

- Indian, afraid of rhinoceros, 96 ; attitude when asleep, 60 ; collision with railway train, 71 ; courage of cows and cowardice of bulls, 58 ; deafness of, 58 ; destructiveness of, 59 ; difficulty of distinguishing in jungle, 26 ; domestication of, 275, 277 ; executed for manslaughter, 54 ; fear of man, 60 ; food of, 59 ; forefoot and height, 52 ; in a circus, 72 ; in Burmese teak forests, 54 ; intelligence of, 64-70 ; migration of, 57 ; persecuted by flies, 64 ; "rogue," $6 \mathrm{I}-4$; shooting, 320; tail lost in fighting, 56 ; trunk of, 52-4 ; tusks of, 55 ; "white," 56

Elk, Difficulty of distinguishing, 26 ; protection of, 325 ; vitality of, 88

"Elk" in America, 224; in Ceylon, 88

Environment, 37, 39

Equatorial jungle, I 47

Everglades, Animal life in the, 3 I

Extinct types, 331

Eye, Power of the human, II 8 


\section{THE WILDERNESS AND JUNGLE}

Fennec, Long ears of the, 191

Feral animals, 295

Field, The (quoted), 18, 65, 108, I1 $8,119,208,257,266$

Firearms, Natives with, 307

Flood and fire, Animals making common cause in, 272

Florida, Extermination of egrets in, 315 ; Keys of, 30 ; protection of alligators in, 322

"Fly" country, 209

Foà, M. (proposal for game protection), 332

Foreign service, Compensations of, $44,45,48$

Forest fires, 28

Four-handed animals, 149

Foxhunting, 43

France, Hunting wild boar in, 82

Fur animals, Slaughter of, 31 5

Game laws, 323-3I

Garden of Allah, Arab tradition of the, 35-7

Genesis, Evidence of the Book of, 270,273

Gharial, Beak of the, I4I

-, Food of the, 142

Gir, Lions of, 39

Giraffe and lion, 166, 193; at play, 193 ; food of, 192 ; hunting and shooting, 16, 17, 194204 ; keen eyesight of, I9I ; remarkable appearance of, $19 \mathrm{I}$

Goisamp, Venom of the, 142

Goldsmith and Dr. Johnson, Anecdote of, 45

Gordon, Adam Lindsay (quoted), 244

Gordon Cumming, Roualeyn, 206

Gordon, Mr. Lewis (killed by a tiger), 257

Gordon's horse, 122, 124

Grant, Lieut. (killed by a tiger), 257

Great Rift Valley, 146
"Great Thirst," The, 37

Grévy's zebra, 204

Grey, Mr. (killed by a lion), 253

Grizzly bear, Adventure with, 229; food of, 228 ; savagery of, 228 ; vitality of, 26 I

Guemal, Small size of, 238

Hamadryad, Man chased by a, $14 \mathrm{I}$

Hannibal, Elephants used by, 278

Harris, Cornwallis, 206, 318

Heloderm, Venom of the, 142

Herapath, Major (quoted), 274

Hippopotamus, Destructiveness of, 190 ; in West Africa, 187 ; native trap for, 188; persecution of, $16,62,63,188$; ugliness of, 187

Hooghly, Crocodiles attacking bathers in the, 144

Hornaday, W. T., 50, 301

Horns of rhinoceros, 73,183 ; of wild sheep, 83 ; of giraffe, 191

Horse, Domesticated, 273, 297

-, Wild, 17

Howdah, Shooting from the, 115,248

Huanaco, Hunting the, 238

Humming-birds, Slaughter of, 316

Hunting-dogs, Adventure with, 168 ; destructiveness of, 168 , 309

Hunting-leopard, 93, 127

"Huskies" (Indian sledge dogs), 291

Hutchinson, General (quoted), 64

Hyenas, Battle between striped, 170

-, Cowardice of, 169

-, Habits of, 170

- imitating growl of panther to frighten bears, 130

- sharing cave with panther, 129 
India, 47-I45; abundance of wild animals in, 47; game laws of, $326,329,330$; lions in, 95 ; natives of, $47,5 \mathrm{I}, 89$, 90, II ; sport in, 50

Indian Mutiny, Camels in the, 286

= Ingram, Mr. (killed by an elephant), 256

Italy, Camels in, 287

Ivory-hunters, Greed of, 278, 320

Jackal, Courage shown by a, 138 ; curious behaviour of a, 138 ; note of the, 97,113

Jaguar, Enmity between puma and, 237 ; food of, 236 ; former friendliness of, 273

James, Mr. F. L. (killed by an elephant), 256

Jemeel (baggage camel), 285

Joonagur, Nawab of (preserves Indian lions), 95

"Jumbo," Death of, 7 I

Jungle Folk, 49

Jungle, Characteristics of the, $33,49,116$

Jungle Book, The, I3I

Kadiak Island, Brown bear of, 232

Kalahari, Elands thriving in the, 207

Kangaroo shooting, 239

Kashmir, 83 ; game laws of, 329 ; "stag" of, 92 ; bears in, I 36, 137

Kathiawar, Lions in, 39, 252

Keddah, 65

Kipling, I 31, 283

Krait, Bite of the, 139

Ladak, 50, 83

Lagden, Sir Godfrey (quoted), 207

Lays of Ind, 117

Lea, Col. S. J. (quoted), 22 I
Le Breton, Mr. (killed by a tiger), 250

Lee-Warner, Sir William (on intelligence in elephants), 65 70

Leopard as a pet, 132 ; cannibal tastes of, 129; destructiveness of, 13, 129, 166; different kinds of, 127 ; fight between cheetah and, I67; man-eating, 128; method of catching monkeys adopted by, IIO; narrow escape from, 260 ; preying on dogs, 128, 131 ; sportsmen killed by, 260

Lewis, Col. D. F. (encounter with lion), I 52

Lions, Alleged magnanimity of, 165 ; and giraffe, 166 ; compared with tiger, 97, 151; destructiveness of, 13, 304; female braver than male, 156 ; Indian, 95 ; in the Bible, 106 ; man-eating, 107; maneless, I 50 ; occasional cowardice of, I $5 \mathrm{I}-9$; pursuing cyclists, $16 \mathrm{I}$, 162 ; range of, 39 ; remarkable adventure with, 253 , roar of, 163 ; slaughtered by Boers, 303; sportsmen killed by, 250-3

Livingstone, 146,246

Llama, 238, 287

London, Draught-dogs in, 292

Longden, Mr. Gerald (killed by an elephant), 256

Longstaff, Dr. T. (quoted), 83 , $96,132,228$

"Lost Man's Friend," The, 303

Lyall, Sir Alfred (quoted), 304

Machan, Shooting from a, 26, $76,77,108,111,248,249$

Machilla, Travel by, 146

McClintock, Sledge-dogs used by, 291

Madeira, Cruelty to bullocks in, 289 


\section{THE WILDERNESS AND JUNGLE}

Mahout, 60, 66, 67, 277; rescued from tiger by elephant, 97

Mammoth, Siberian, 58

Man-eater, Evolution of the, 104-7; scarce in Nilgiris, I06; sex of, 106

Man-eaters of Tsavo, The, 107, 251

Maneless lions, I 50

Mangrove swamps, Animal life in the, $3 \mathbf{I}$

Markhor, Horns of the, 83

Marsh Deer, 237

"Maximus" wrongly applied to the Indian elephant, 52

Méhari (swift camel), 285

Mesmerising tigers, 117

Mesopotamia, Lions in, 95

Mhow, Elephant executed at, 54

Migrations, Animal, 38, 85, 86

Miramichi, The River, 27

Mistakes made by animals, Iog

Moffatt (narrow escape from cobra and lion), 246

Molony, Lieut. (mauled by lion), 252

Mongoose, Tactics of the, 140

Monkeys betray the whereabouts of big game, 150; preyed on by tigers, 108; by leopards, 110

Moose, Calling, 22I-3 ; disturbing $a, 29$; evicted by whitetailed deer, 223 ; food of, 220 ; identical with European elk, 220; poached in summer months, 220

Morgan, Prof. Lloyd (quoted), 109

Mosquitoes in Newfoundland, 216

Mountain transport, Elephants used for, 279 ; yaks for, 288

Mule deer, Range of, 227

Muntjac as a pet, I33; teeth of, 133

Murray, Colonel (quoted), 249
Murray, Major (quoted), 257

Musk ox, Method of hunting, 217

"Must" in elephants, 6r

Mysore, Elephant shooting in, 63

Nandi lion-hunters, 243

Nansen, Sledge-dogs used by, 291

Nature-teaching, 10, I I

Neave, Mr. (killed by a sloth bear), 26I

Negro, Ways of the, $14,148,15$ I, $276,277,296,307,319$

Nepal, Rhinoceros in, 73

"Never Never," the, 37

Neumann, Mr. Arthur (gored by an elephant), 256, 320

New Brunswick, Game laws of, 328

Newfoundland, Mosquitoes in, 216

"Nile-horse," 187

Nilgiris, Game laws in the, 329

Okapi, Discovery of the, 147

Oswell (tossed by black and white rhinoceros), 246

Otter trained to catch fish, 295

Outram, Sir James (adventure with a tiger), I17

Ovis ammon and 0. poli, 83

Panther afraid of wild boar, 75 ; and hyena sharing same cave, I 29; on a railway, 47

Park, Mungo, 146

Patterson, Colonel, 10

Peary, Sledge-dogs used by, 29I

Penang, Crocodiles on the coast of, I44

Penguins, Fearlessness of, 273

Persia, Lions in, 95

Pet animals, 80, 132, 133, 136, 274

Pigsticking, 74, 80

Pioneer Mail (quoted), 128, 259 
Pitfalls for wild boar, 82

Poer, Mr. H. C. de la (adventure with lions), 154

Porcupine in camp, 28 ; protection of, 305

Pronghorn antelope in the Yellowstone, 219

Protective colouring, 25

Puma, Alleged friendliness of, 236 ; enmity between jaguar and, 237 ; hunting with dogs, - 235

Python, Encounter with a, 26

Quagga exterminated by Boers, 204, 3I 3

Queensland, Mangrove swamps in, $3 \mathbf{I}$

Railway trains, Encounters between wild animals and, 47, $48,71,72$

Rangoon Gazette (quoted), 96

"Ranjitsinhji" bags an Indian lion, 95

Rat, A tame, 274

Red Bear, 137

Reedbuck and lion, 208

Reid, Mr. Percy (adventures with lions), I 53, I 56-60

Reindeer, Taming of the, 17 , 289,290

Restigouche, Salmon-fishing in the, 215

Rhinoceros, attracted by camp fires, 186 ; elephant afraid of, 96 ; horns of, 73,183 ; immune from rinderpest, 309 ; methods of fighting, 73,184 ; nervousness of, 75,185 ; slaughter of, $32 \mathrm{I}$; squaremouthed, 184,185

Rhodesia, Elephant-shooting in, I6, 174-82

Rifles and ammunition, Performances with modern, 247, 32 I

Rinderpest, Depredations of, 308, 309
Roberts, Lord (and cats), 98

Rocky Mountain goat, Foolishness of the, 218

"Rogue" elephants, Theories concerning, 6I-4, 295

Rook and squirrel, Fight between, III

Roosevelt, Giraffe shot by, 194 ; rhinoceros shot by, 185,321

Rospoli, Prince (killed by an elephant), 194

Royal Colonial Institute, The, 18

Royal Society for Prevention of Cruelty to Animals, 289, 292

Russell, Mr. Robert (killed by a buffalo), 263

Russian forest, Daybreak in a, 26,27

Sable antelope, Native killed by a, 264

Salisbury Plain, Solitude of, 23

Salmon-fishing, 43

Sambur, Antlers of, 88 ; young (escaping notice), 9I

Sanctuaries for big game, 3oI, 3 II

Sandbach, Major (killed by a lioness), 250

Saunders, Capt. A. (bitten by a lion), 252

Sea, Crocodiles attacking bathers in the, 144

Selous, F. C. Mr., early memories of, 146 ; encounters with wild beasts, I84, 244, $246,252,262$; on armed native question, 319 ; on buffalo and tsetse-fly, 210 ; on character of buffalo, 264 ; on eland flourishing in the Kalahari, 207

Sense of proportion, Importance of a, 45

Senses of wild animals, 24, 25

Sentinels, Wild animals as, 84

Seoni, I3I 


\section{THE WILDERNESS AND JUNGLE}

Seton-Karr, Sir H. (quoted), $24,25,26,63,156,225$

Sharpe, Mr. Reginald (quoted), 208

Sheep, Domestication of the, 273,275 ; wild, 83,217

"Ship of the desert," 283

Sledge-dogs and Eskimo children, 277, 29I

Sleeping Sickness, Ravages of, 147

Sloth bear as a pet, 136 ; food of, 136; inappropriate name of, 135

Snake-charmers, I4I

Snakes, Venom of, 140

Snow-leopard, 127

Society for the Preservation of the Wild Fauna of the Empire, 12

Somali herdsman a fighter, 276

South America poor in big game, 234

Spain, Camels in, 287, 296; game laws of, 324

Sport, The freedom of, I4

Squirrel and rook, Fight between, III

Stags, Duels between, I70

Steinbok, Courage of the, 207

Steller's Sea-cow, Extermination of, 3I4

Stevenson - Hamilton, Major (quoted), 306, 319

Stigand, Capt. (killed by leopard), 260

Stromboom (encounter with giraffe), 193

Suakin Field Force, 287

Sunderbunds, Tiger-shooting in the, 116

Swamp-deer (see Barasingh)

Sweden, Elk in, 88

Swiss Lake Dwellings, Evidences of the, 27 I

Switzerland, Game laws of, 324

Sword-hunters, Arab, I6

Syria, Tame buffaloes in, 277
Talbot, Major (quoted), 87, I 1 14I, 257

Taming, Meaning of, 274

Tangier, Pigsticking near, 74

Teale, Mr. (killed and eaten by a lion), $25 \mathrm{I}$

Thomson, Mr. (tossed by a buffalo), 262

Thomson-Seton, Mr. (quoted), 288

Tibet, 50,84

Tiger, able to climb, II2; and swim, II 4 ,

-, Adventures with, 258, 259

- as pet, 132

-, Cowardice of, 115

- cubs taken alive, 120

-, Destructiveness of, 13

-, Food of, 103

- in the Sunderbunds, 116

- killed by unarmed native, I19; with spear and dagger, II7

-, Lion compared with, 97

-s method of catching monkeys, 108; and of eating victim, 128

-, Mesmerising a, II7

- routed by elephant, 96

- shooting in Mysore, 121

-, Sportsmen killed by, 257

-s, two, at one shot, 126

"Tiger-cry" of the jackal, II 3

Todas and their buffaloes, 277

Transvaal, Extermination of big game in the, 318; Game Reserve, 306

Travancore, Elephant-shooting in, 63

Travel, Easy conditions of modern, 44

Trophies, Greed for, 332

Tsavo, Man-eating lions at, I07, 152

Tsetse-fly, The, I47, 309

Turkey, Game laws of, 324 ; Treatment of horses in, 289 


\section{INDEX}

Uganda Railway, 146

United States, Game laws of the, 326

Van der Byl, Mr. P. B. (adventure with a leopard), 260, 26r,

Venom of lizards, 142 ; of, snakes, I40

Ventriloquist, An Abyssinian, 164

Virginian deer in Canada, 227

Von Koppenfels (killed by a buffalo), 263

Vulture, Marvellous eyesight of the, 17 I

Wahlberg (killed by an elephant), 256

Wapiti-shooting, 224

Warfare, Camels in, 285, 286 ; elephants in, 278

Wart-hog, Appearance and habits of, 213

Waterbuck, Man killed by a, 264

"Water-elephant," Newly-discovered, 183
"White" elephant, 56; rhinoceros, 183

Whitney, Mr. Caspar (quoted), 262

Wild boar, dog, sheep, etc. (see Boar, Dog, Sheep)

Wildebeest and cheetah in Paris Zoo, 294 ; grotesque appearance of, 208 ; protection of black, 317

Wilderness, The, 17

Williamson, Colonel (quoted), 79, 90, I 10, I24, 132, I33, I34, 138

Wolhuter, Mr. (remarkable adventure with two lions), 253

Wolves attacking man, 233

Yak in Canada, 288 ; size and strength of, 84 ; taming of, 17 , 84,288

York, Mr. (killed by an elephant), 256

Zebra, 204, 205; in harness, 297 


\section{Our Agreeable Friends}

The Times. - ". a volume which should be a delight to any boy who is fond of animals."

The Pall Mall Garette.- "Mr. Aflalo is one of those authors to whom the experienced reader yields his perfect confidence, both as a naturalist and as a writer, and to no one could we send young people to learn about animals with so strong an assurance that they will be taught in the most pleasant, as well as the most educative way."

The Daily News, _ "Such a collection of animal stories as this is for all time."

Freeman's Journal. - "This is a charming book of anecdotes about animals... . The stories are charmingly told."

The Sheffeld Daily Telegraph._" ". . Nobody tells animal stories better than Mr. Aflalo." 




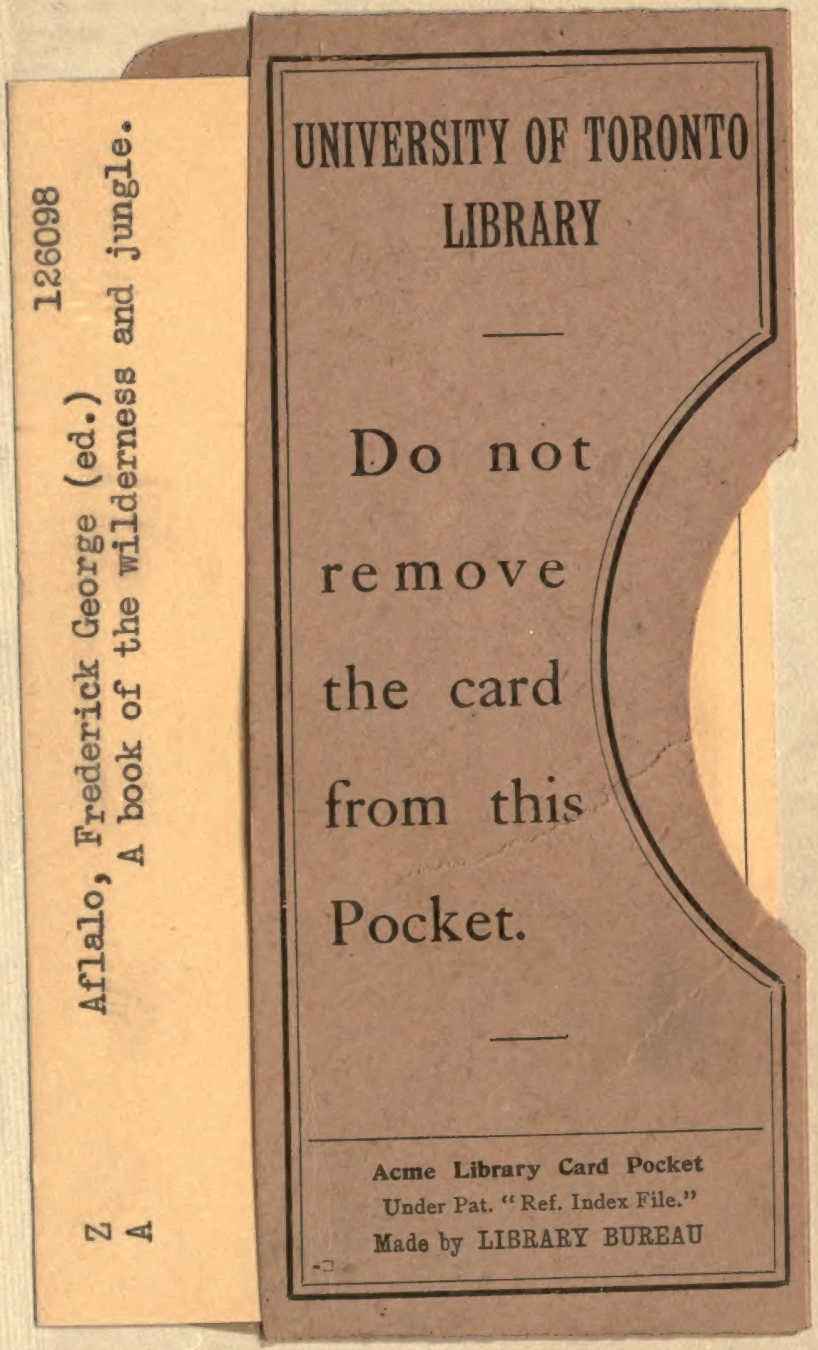


